Prepared in cooperation with the Pennsylvania Department of Environmental Protection, the Susquehanna River Basin Commission, and The Nature Conservancy

\title{
Estimation of Baseline Daily Mean Streamflows for Ungaged Locations on Pennsylvania Streams, Water Years 1960-2008
}
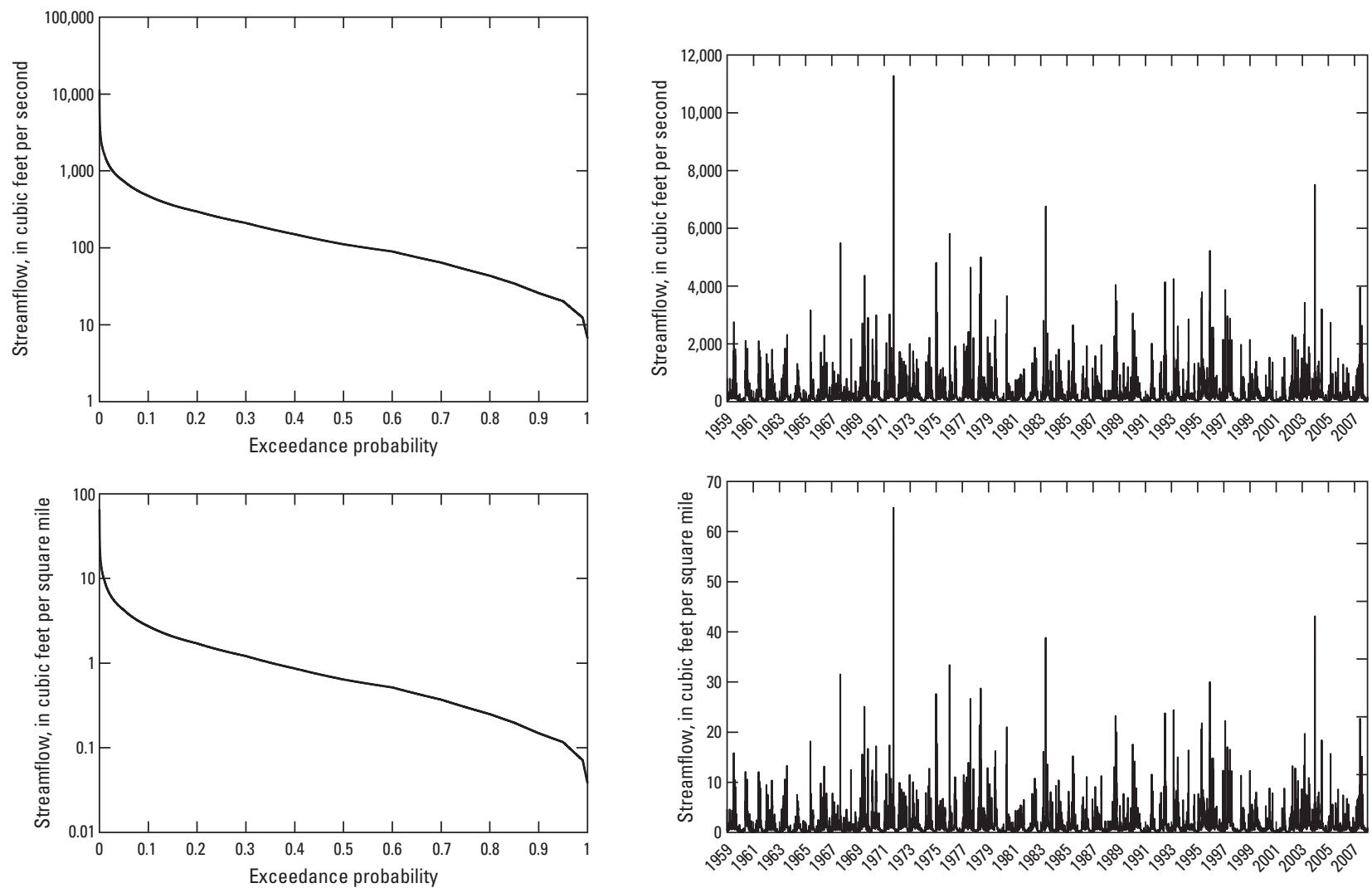

Scientific Investigations Report 2012-5142

Version 1.1, August 2014

U.S. Department of the Interior

U.S. Geological Survey 
Cover. Estimated flow-duration curves and hydrographs generated by the Baseline Streamflow Estimator. 


\section{Estimation of Baseline Daily Mean Streamflows for Ungaged Locations on Pennsylvania Streams, Water Years 1960-2008}

By Marla Stuckey, Edward Koerkle, James Ulrich

Prepared in cooperation with

the Pennsylvania Department of Environmental Protection, the Susquehanna River Basin Commission, and The Nature Conservancy

Scientific Investigations Report 2012-5142

Version 1.1, August 2014 


\title{
U.S. Department of the Interior \\ KEN SALAZAR, Secretary \\ U.S. Geological Survey \\ Marcia K. McNutt, Director
}

\author{
U.S. Geological Survey, Reston, Virginia \\ First release: 2012 \\ Revised: August 2014 (ver. 1.1)
}

\begin{abstract}
For more information on the USGS - the Federal source for science about the Earth, its natural and living resources, natural hazards, and the environment, visit http://www.usgs.gov or call 1-888-ASK-USGS.

For an overview of USGS information products, including maps, imagery, and publications, visit http://www.usgs.gov/pubprod

To order this and other USGS information products, visit http://store.usgs.gov
\end{abstract}

\footnotetext{
Any use of trade, product, or firm names is for descriptive purposes only and does not imply endorsement by the U.S. Government.

Although this report is in the public domain, permission must be secured from the individual copyright owners to reproduce any copyrighted materials contained within this report.
}

Suggested citation:

Stuckey, M.H., Koerkle, E.H., and Ulrich, J.E., 2014, Estimation of baseline daily mean streamflows for ungaged locations on Pennsylvania streams, water years 1960-2008 (ver. 1.1, August 2014): U.S. Geological Survey Scientific Investigations Report 2012-5142, 61 p., http://pubs.usgs.gov/sir/2012/5142. 


\section{Acknowledgments}

The authors thank Stacey Archfield of the U.S. Geological Survey for providing technical expertise and support on the use of the QPPQ and map correlation method. The authors also thank Brandon Fleming, Chris Gazoorian, and Curtis Schreffler of the U.S. Geological Survey for their technical reviews of both the report and BaSE; Hoss Liaghat and Mike Hill of the Pennsylvania Department of Environmental Protection, Greg Cavallo of the Delaware River Basin Commission, and Michele DePhilip and Tara Moberg of The Nature Conservancy for their reviews and testing of Baseline Streamflow Estimator; Scott Hoffman of the U.S. Geological Survey for his GIS support; and the Hydrologic Surveillance Program staffs in the U.S. Geological Survey Pennsylvania, Maryland, New York, Ohio, and West Virginia Water Science Centers for their compilation and review of streamgage data. 


\section{Contents}

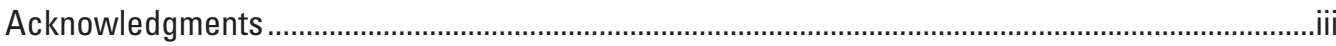

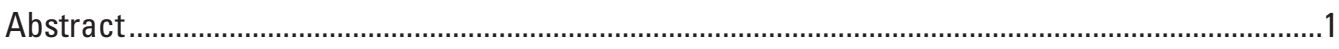

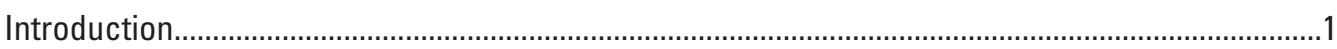

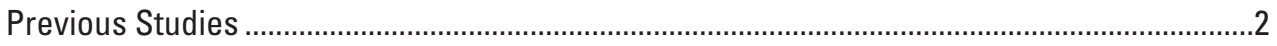

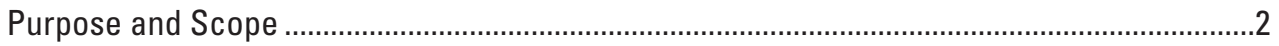

Estimation of Baseline Daily Mean Streamflow .........................................................................

Reference Streamgages in Pennsylvania and Surrounding States..........................................

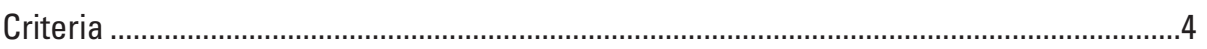

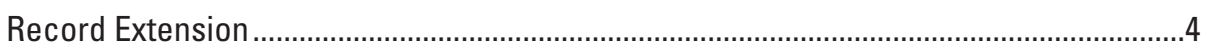

Regression Equations for Estimating Flow-Duration Exceedance Probabilities .......................7

Streamgages and Basin Characteristics Used in Regression Analysis ............................7

Regression Analysis and Resulting Flow-Duration Exceedance Probability

Regression Equations ..........................................................................................

Selection of Reference Streamgages for Estimating Baseline Daily Mean Streamflow .......12

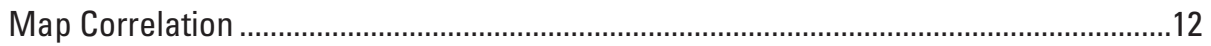

Application of Map Correlation in Two Pilot Basins .............................................12

Correlation Metrics ......................................................................................12

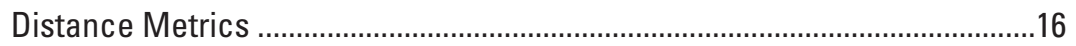

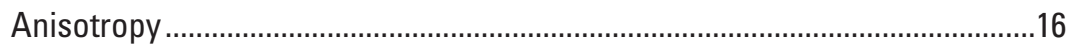

Analysis and Results of Map Correlation in Two Pilot Basins...................................17

Statewide Map Correlation Development .........................................................................18

Use of BaSE for Estimating Baseline Daily Mean Streamflow for Ungaged Locations....................20

Accuracy and Limitations of Estimated Baseline Streamflows ........................................................20

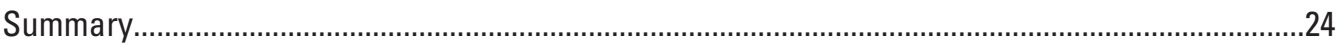

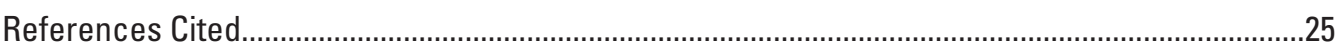

Appendix 1. Description of reference streamgages used in the development of BaSE

for Pennsylvania with period of record and use of data ...............................................28

Appendix 2. Reference streamgages with record extension techniques applied ........................34

Appendix 3. Basin characteristics used in the development of flow-duration regression equations ......................................................................................................4

Appendix 4. Flow-duration exceedance probabilities, observed and computed from streamflow data, and regression equations for streamgages used in regression analysis

Appendix 5. User's Guide for the Baseline Streamflow Estimator (BaSE) .................................57 


\section{Figures}

1. Schematic design of the QPPO method used in the Baseline Streamflow Estimator (BaSE) showing, $A$, observed daily mean streamflow at a reference streamgage, $B$, flow duration curve at the reference streamgage, $C$, constructed flow duration curve at the ungaged location, and, $D$, estimated daily mean streamflow at the ungaged location.

2. Map showing location of U.S. Geological Survey reference streamgages in and near Pennsylvania

3. Map showing normalized net water use in selected U.S. Geological Survey streamgage basins in Pennsylvania, 2003...

4. Example correlation map for U.S. Geological Survey streamgage 01559000, Juniata River at Huntingdon, $\mathrm{Pa}$.

5. Map showing location of pilot test basins in Pennsylvania and reference streamgages for the map correlation method.

6. Boxplots showing distribution of Nash-Sutcliffe efficiency values computed from observed and estimated correlations of daily mean streamflows at selected U.S. Geological Survey streamgages in, $A$, the Lower Susquehanna River Basin and, $B$, the Upper Delaware River Basin in Pennsylvania.

7. Graph showing success rate for selection of the best correlated streamgage by using distance and map correlation methods applied in the pilot basins

8. Screen capture of report generated by the BaSE tool showing flow duration curves and a hydrograph....

9. Graphs showing observed and estimated daily mean streamflow for U.S. Geological Survey streamgage 01548500 Pine Creek at Cedar Run, Pa., using, $A$, log-linear interpolation and, $B$, log-log interpolation

10. Boxplots showing distribution of, $A$, Nash-Sutcliffe efficiency values and, $B$, root mean square error obtained from comparison between observed and estimated daily mean streamflows in the two pilot basins in Pennsylvania

11. Hydrographs and flow duration curves showing estimated and observed daily mean flows for U.S. Geological Survey streamgages, A, 01556000, Frankstown Branch Juniata River at Williamsburg, Pa., and, B, 01452500, Monocacy Creek at Bethlehem, $\mathrm{Pa}$.

\section{Tables}

1. Basin characteristics used in the development of regression equations for flow-duration exceedance probabilities for Pennsylvania streams.

2. Regression coefficients for use with flow-duration exceedance probability regression equations for Pennsylvania streams

3. Description of selected U.S. Geological Survey reference streamgages in the Upper Delaware River Basin and the Lower Susquehanna River Basin in Pennsylvania .........15

4. Summary of map correlation application in two pilot basins in Pennsylvania . .19

5. Mean streamflow correlations for reference streamgages used in the map correlation method for Pennsylvania streams, by drainage area and major basin

6. Basin characteristics with minimum, maximum, and mean values used in development of regression equations to estimate flow-duration exceedance probabilities with BaSE for basins in Pennsylvania. 


\section{Conversion Factors}

Inch/Pound to SI

\begin{tabular}{|c|c|c|}
\hline Multiply & By & To obtain \\
\hline \multicolumn{3}{|c|}{ Length } \\
\hline inch (in.) & 2.54 & centimeter $(\mathrm{cm})$ \\
\hline foot $(\mathrm{ft})$ & 0.3048 & meter $(\mathrm{m})$ \\
\hline mile (mi) & 1.609 & kilometer $(\mathrm{km})$ \\
\hline \multicolumn{3}{|c|}{ Area } \\
\hline acre & 4,047 & square meter $\left(\mathrm{m}^{2}\right)$ \\
\hline square mile $\left(\mathrm{mi}^{2}\right)$ & 259.0 & hectare (ha) \\
\hline square mile $\left(\mathrm{mi}^{2}\right)$ & 2.590 & square kilometer $\left(\mathrm{km}^{2}\right)$ \\
\hline \multicolumn{3}{|c|}{ Volume } \\
\hline gallon (gal) & 0.003785 & cubic meter $\left(\mathrm{m}^{3}\right)$ \\
\hline gallon (gal) & 3.785 & cubic decimeter $\left(\mathrm{dm}^{3}\right)$ \\
\hline million gallons (Mgal) & 3,785 & cubic meter $\left(\mathrm{m}^{3}\right)$ \\
\hline acre-foot (acre-ft) & 1,233 & cubic decimeter $\left(\mathrm{dm}^{3}\right)$ \\
\hline acre-foot (acre-ft) & 0.001233 & cubic meter $\left(\mathrm{m}^{3}\right)$ \\
\hline \multicolumn{3}{|c|}{ Flow rate } \\
\hline cubic foot per second $\left(\mathrm{ft}^{3} / \mathrm{s}\right)$ & 0.02832 & cubic meter per second $\left(\mathrm{m}^{3} / \mathrm{s}\right)$ \\
\hline $\begin{array}{l}\text { cubic foot per second per square mile } \\
{\left[\left(\mathrm{ft}^{3} / \mathrm{s}\right) / \mathrm{mi}^{2}\right]}\end{array}$ & 0.01093 & $\begin{array}{l}\text { cubic meter per second per square } \\
\text { kilometer }\left[\left(\mathrm{m}^{3} / \mathrm{s}\right) / \mathrm{km}^{2}\right]\end{array}$ \\
\hline cubic foot per day $\left(\mathrm{ft}^{3} / \mathrm{d}\right)$ & 0.02832 & cubic meter per second $\left(\mathrm{m}^{3} / \mathrm{s}\right)$ \\
\hline gallon per day (gal/d) & 0.003785 & cubic meter per day (m3/d) \\
\hline gallon per day per square mile $\left[(\mathrm{gal} / \mathrm{d}) / \mathrm{mi}^{2}\right]$ & 1,233 & cubic meter $\left(\mathrm{m}^{3}\right)$ \\
\hline million gallons per day $(\mathrm{Mgal} / \mathrm{d})$ & 0.001233 & cubic hectometer $\left(\mathrm{hm}^{3}\right)$ \\
\hline
\end{tabular}

Temperature in degrees Fahrenheit $\left({ }^{\circ} \mathrm{F}\right)$ may be converted to degrees Celsius $\left({ }^{\circ} \mathrm{C}\right)$ as follows: ${ }^{\circ} \mathrm{C}=\left({ }^{\circ} \mathrm{F}-32\right) / 1.8$

Vertical coordinate information is referenced to the North American Vertical Datum of 1988 (NAVD 88).

Horizontal coordinate information is referenced to the North American Datum of 1983 (NAD 83).

Altitude, as used in this report, refers to distance above the vertical datum. 


\title{
Acronyms
}

\author{
BaSE Baseline Streamflow Estimator \\ FDC Flow duration curve \\ GIS Geographic Information System \\ GNWISO Get NWIS WEB Streamflow Data Files \\ HUC Hydrologic Accounting Unit Code \\ LOC Line of organic correlation \\ MASYE Massachusetts Safe Yield Estimator \\ MkPP Make Plotting Position File \\ MOVE Maintenance of variance \\ NS Nash-Sutcliffe efficiency value \\ NWIS National Water Information System \\ OLS Ordinary least squares regression \\ Pn nth percentile from flow duration curve \\ QPPO Methodology equating the streamflow as a percentile from a flow duration curve for \\ a particular day at an ungaged location to the streamflow as a percentile from the \\ flow duration curve for the same day at a reference streamgage \\ RMSE Root mean square error \\ SREF Streamflow Record Extension Facilitator \\ WLS Weighted least squares regression \\ WY Water year
}




\title{
Estimation of Baseline Daily Mean Streamflows for Ungaged Locations on Pennsylvania Streams, Water Years 1960-2008
}

\author{
By Marla H. Stuckey, Edward H. Koerkle, and James E. Ulrich
}

\section{Abstract}

Water-resource managers use daily mean streamflows to generate streamflow statistics and analyze streamflow conditions. An in-depth evaluation of flow regimes to promote instream ecological health often requires streamflow information obtainable only from a time series hydrograph. Historically, it has been difficult to estimate daily mean streamflow for an ungaged location. The U.S. Geological Survey, in cooperation with the Pennsylvania Department of Environmental Protection, Susquehanna River Basin Commission, and The Nature Conservancy, has developed the Baseline Streamflow Estimator (BaSE) to estimate baseline streamflow at a daily time scale for ungaged streams in Pennsylvania using data collected during water years 1960-2008. Baseline streamflow is minimally altered by regulation, diversion, or mining, and other anthropogenic activities. Daily mean streamflow is estimated in BaSE using a methodology that equates streamflow as a percentile from a flow duration curve for a particular day at an ungaged location with streamflow as a percentile from the flow duration curve for the same day at a reference streamgage that is considered to be hydrologically similar to the ungaged location. An appropriate reference streamgage is selected using map correlation, in which variogram models are developed that correlate streamflow at one streamgage with streamflows at all other streamgages. The percentiles from a flow duration curve for the ungaged location are converted to streamflow through the use of regression equations. Regression equations used to predict 17 flow-duration exceedance probabilities were developed for Pennsylvania using geographic information system-derived basin characteristics. The standard error of prediction for the regression equations ranged from 11 percent to 92 percent with the mean of 31 percent.

The map correlation method for estimating streamflow was tested at locations within two pilot basins, the Upper Delaware River Basin and the Lower Susquehanna River Basin, before being applied statewide. Reference streamgages within the pilot basins were used as ungaged locations for analyzing the map correlation method. Correlation using Spearman's rho and centroid distance performed as well as, or better than, the method using the closest streamgage as a reference streamgage. Map correlation using the correlation metrics identified in the pilot basins was applied to 156 streamgages in and near Pennsylvania.

BaSE uses the map correlation method and flow-duration exceedance probability regression equations to estimate baseline daily mean streamflow for an ungaged location. The output from BaSE is a Microsoft Excel ${ }^{\circledR}$ report file that summarizes the reference streamgage and ungaged location information, including basin characteristics, percent difference in basin characteristics between the two locations, any warning associated with the basin characteristics, mean and median streamflow for the ungaged location, and a daily hydrograph of streamflow for water years 1960-2008 for the ungaged location. The daily mean streamflow for the ungaged location can be exported as a text file to be used as input into other statistical software packages. BaSE estimates daily mean streamflow for baseline conditions only, and any alterations to streamflow from regulation, large water use, or substantial mining are not reflected in the estimated streamflow.

\section{Introduction}

The natural flow regime of a stream or river is vital to the sustainability and health of aquatic freshwater ecosystems. The ability to characterize baseline, or minimally altered, streamflow conditions, compare them with current conditions, project future conditions, and assess effects of human activities on streamflow is fundamental to water-management programs addressing water allocation, human-health issues, recreation needs, and establishment of ecological flow criteria. Water-resource managers undertaking an in-depth evaluation of flow regimes to promote instream ecological health often require daily mean streamflow information obtainable only 
from a time series hydrograph. Daily mean streamflow allow water-resource managers to assess streamflow and determine streamflow statistics that fulfill their individual needs.

State, Federal, and local agencies have been working collaboratively on aquatic instream flow needs and developing environmental flow criteria for water management in Pennsylvania (DePhilip and Moberg, 2010). To assist in this effort, the U.S. Geological Survey (USGS), in cooperation with the Pennsylvania Department of Environmental Protection (PaDEP), Susquehanna River Basin Commission (SRBC), and The Nature Conservancy (TNC), has developed a tool to estimate minimally altered, or baseline, streamflow at a daily time scale for ungaged streams in Pennsylvania. The Baseline Streamflow Estimator (BaSE) will provide hydrologists, ecologists, and water managers streamflow information to effectively assess baseline streamflow conditions as related to water allocation, aquatic instream-flow needs, and water availability. A range of ecologically relevant flow statistics can be computed from estimated daily mean streamflow using statistical software packages, such as Indicators of Hydrologic Alteration (IHA) (The Nature Conservancy, 2009) and Hydroecological Integrity Assessment Tool (HAT) (Henriksen and others, 2006).

\section{Previous Studies}

Fennessey (1994) introduced a method to estimate streamflow statistics for an ungaged location (termed "QPPQ" method). This method was used by Hughes and Smakhtin (1996), Smakhtin (1999), Smakhtin and Masse (2000), Mohamoud (2008), Archfield and others (2010), and Shu and Ourda (2012). Archfield and Vogel (2010) developed a method for selecting reference streamgages for an ungaged location on the basis of streamflow correlation (termed the "map correlation method"). This method has been successfully applied in Massachusetts (Archfield and others, 2010) and the Connecticut River Basin (Stacey Archfield, U.S. Geological Survey, written commun., 2012). The combination of the QPPQ method and map correlation method for selecting an appropriate reference streamgage was incorporated into the Massachusetts Sustainable-Yield Estimator (MASYE) by Archfield and others (2010). The combination of methods, or parts thereof, is being developed for applications in New York and Maryland (Ward Freeman, U.S. Geological Survey, oral commun., 2011, and Brandon Fleming, U.S. Geological Survey, oral commun., 2011). A report from The Nature Conservancy (TNC; Apse and others, 2008) for the Pennsylvania Instream Flow Technical Advisory Committee describes studies conducted to assess instream flow needs, presents methods, and describes the Ecological Limits of Hydrologic Alteration (Poff and others, 2010).

Regression equations are used to estimate streamflow characteristics where streamgage data are not available. Regression equations have not been developed for flowduration exceedance probabilities in Pennsylvania; however, regression equations have been developed for estimating low-flow, mean-flow, and base-flow statistics (Stuckey, 2006), as well as flood-frequency statistics (Roland and Stuckey, 2008). Flow-duration statistics for more than 500 streamgages in and near Pennsylvania are presented by Stuckey and Roland (2011). Regression estimates and streamflow statistics can be found for gaged and ungaged streams in Pennsylvania at the StreamStats web application (http://water.usgs.gov/osw/ streamstats/pennsylvania.html) (Stuckey and Hoffman, 2010).

\section{Purpose and Scope}

This report presents the data and methodology used to estimate minimally altered (baseline) daily mean streamflow for water years ${ }^{1} 1960$ to 2008 for ungaged locations on streams in Pennsylvania. Parameter-based regression equations used to predict 17 exceedance probabilities from the flow duration curve (FDC) for ungaged streams in Pennsylvania are presented. Flow-duration exceedance probabilities for 162 streamgages are presented. Streamflow data from continuous-record streamgages were used to develop correlation maps of the predicted correlation of streamflow between an ungaged location and a reference streamgage. A description and instructions for the use of BaSE, a tool for estimating baseline daily mean streamflow for Pennsylvania streams, are presented.

\section{Estimation of Baseline Daily Mean Streamflow}

The BaSE tool for estimating baseline daily mean streamflow for ungaged locations on Pennsylvania streams is based on the QPPQ method (Fennessey, 1994; Hughes and Smakhtin, 1996; Smakhtin, 1999; Smakhtin and Masse, 2000; Mohamoud, 2008; Archfield and others, 2010; and Shu and Ourda, 2012), which equates streamflow expressed as a percentile from the FDC for a particular day at an ungaged location with the percentile from a FDC for the same day at a hydrologically similar location where streamflow is measured (referred to as "reference streamgage"). A graphical depiction of the QPPQ methodology is shown in figure 1. Geospatial correlation of streamflow (Archfield and others, 2010) is used to select a reference streamgage for the ungaged location. Streamflows corresponding to the flow-duration exceedance probability for the ungaged location are selected from a daily FDC constructed from points determined by regression equations. This method was successfully applied in Massachusetts and incorporated into the MASYE (Archfield and others, 2010).

The FDC for the reference streamgage is a cumulative frequency curve that shows the percentage of time that

\footnotetext{
${ }^{1}$ Water year (WY) is defined as a 12-month period beginning October 1 and ending September 30. The water year is designated by the calendar year in which it ends.
} 

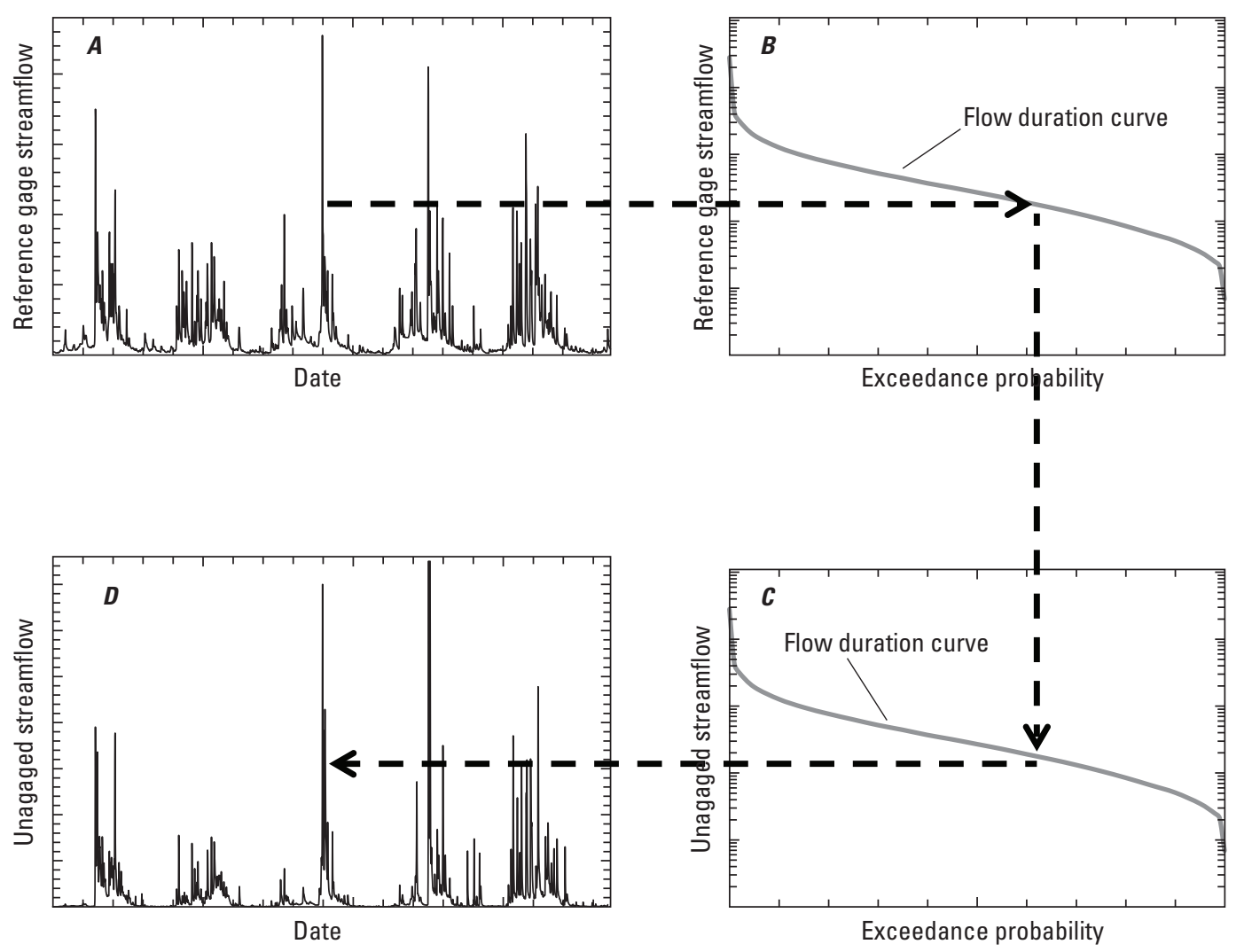

Figure 1. The QPPQ method used in the Baseline Streamflow Estimator (BaSE) showing, $A$, observed daily mean streamflow at a reference streamgage, $B$, flow duration curve at the reference streamgage, $C$, constructed flow duration curve at the ungaged location, and, $D$, estimated daily mean streamflow at the ungaged location. (Modified from Archfield and others, 2010)

specified streamflows are equaled or exceeded (Searcy, 1959). It is constructed by arranging observed streamflow values for a given period of time by magnitude and the percentage of time observed daily streamflow values equaled or exceeded a specific streamflow. For this report, the percentage of time that the streamflow is equaled or exceeded is "exceedance probability" and is used when discussing statistics. An individual exceedance probability is "percentile" for this report and is used when discussing methodology associated with a generic FDC.

The FDC for an ungaged location is constructed from estimates of streamflow for 17 percentiles. Streamflow is estimated for each of the 17 percentiles by use of regression equations developed using basin characteristics and streamflow data from a subset of reference streamgages. Streamflow for all other percentiles is determined by interpolation. Interpolation of streamflow between exceedance probabilities determined from the 17 regression equations yields a continuous daily hydrograph consisting of 17,898 streamflow values (one value for each day in water years 1960-2008) for the ungaged location.
A critical consideration in estimating baseline daily mean streamflow is the selection of the reference streamgage that results in the best estimate of daily streamflow at the ungaged location. Selection of a reference streamgage is performed using map correlation (Archfield and others, 2010; Archfield and Vogel, 2010). Map correlation is a geostatistical procedure for determining the streamgage with streamflow that exhibits the strongest correlation with streamflow at an ungaged location.

\section{Reference Streamgages in Pennsylvania and Surrounding States}

A reference streamgage constitutes a composite of the upstream land cover, geology, and hydrologic characteristics and can be used to represent ungaged basins with similar characteristics. Reference streamgages are used by water-resource managers for a variety of purposes, including regulatory decisions, drought and flood forecasting, and long-term baseline 
data collection. Data on observed streamflows at reference streamgages are used in this analysis to develop regression equations for estimating exceedance probabilities and for development of correlation maps.

\section{Criteria}

Reference streamgages selected for this baseline analysis had streamflow that was minimally altered by regulation, diversion, or mining, and other anthropogenic activities, and had at least 10 years of continuous record; however, one streamgage with 8 years of record was included to increase spatial coverage. Most of the streamgages (152) had 15 or more years of record; the average number of years of record is 46 years. Substantial regulation for this analysis is represented by upstream reservoir impoundments that control at least 10 percent of the contributing drainage area at the streamgage. Streamgages with questionable regulation were further evaluated graphically by comparing the range and median of the streamflows before and after construction of the impoundment and were evaluated statistically by using a two-sample Kolmogorov-Smirnov goodness of fit test (TIBCO Software Inc., 2008). For streamgages with at least 10 years of unregulated flow data recorded before the impoundment was constructed, only the period prior to the start of regulation was used in the analysis. Information on diversions and mining affects were obtained from USGS Annual Water Data Reports, available on-line only since 2006 at $h t t p: / / w d r$ water.usgs.gov/ and in paper format prior to 2006 on file at the USGS Pennsylvania Water Science Center. There were 168 streamgages that potentially met the above criteria-143 in Pennsylvania, 10 in New York, 6 in Maryland, 2 in West Virginia, and 7 in Ohio (fig. 2). A complete listing of streamgages used in the analysis is presented in appendix 1 .

The percentage of impervious area within a basin was used to limit the number of streamgages with potential anthropogenic effects on streamflow. However, in large urban/ suburban areas, such as in the southeastern part of the State, some streamgages with a high percentage of impervious area were retained for improved spatial coverage. The average percentage of impervious area for the streamgages selected for the analysis is 2.5 ; with a maximum of 29 percent allowed in southeastern Pennsylvania.

Water use in Pennsylvania, including registered withdrawals, estimated withdrawals, and discharges for 2003 (Stuckey, 2008), were used to evaluate the selected streamgages. Because of uncertainties associated with the water-use data, including lack of verification or adjustment for storage, pass-by flows, or other drought-specific requirements, the data were not used independently to exclude streamgages but rather as a check of streamgages that exhibited unusual streamflow characteristics. The net water use (total discharges - total withdrawals) normalized to the drainage area associated with the selected streamgages within Pennsylvania is shown in figure 3. Positive values in the normalized net water use indicate more water is being returned to the basin than is being withdrawn, either through discharges, such as wastewatersewage-treatment plants, or importation of water from outside the basin. Negative values indicate more water is being withdrawn for multiple purposes or being exported out of the basin than is being returned. Streamgages in the combined Upper and Lower Delaware River Basins had the highest normalized water use per square mile overall with more water being consumed or exported in the Upper Delaware River Basin and more water being discharged or imported in the Lower Delaware (fig. 3).

\section{Record Extension}

Estimation of daily mean streamflow using the QPPQ method for WY 1960 to 2008 for any ungaged stream location requires that all reference streamgages have a complete daily streamflow record for the same period. Of the selected reference streamgages, 67 had a complete record with unregulated flow for WY 1960 to 2008. The remaining streamgages had record lengths of 8 to 48 years. Streamflow records shorter than 49 years were extended to complete the 1960-2008 WY period using the Streamflow Record Extension Facilitator (SREF) (Granato, 2009). The average number of incomplete years of record during WY 1960-2008 that required record extension was 25 years, with a range of 1 year to 44 years. No estimated streamflow data from the record extension analysis were used in the development of regression equations or correlation maps.

The methodology used for the SREF relies on the assumption that long-term streamflow records from hydrologically similar streamgages can be used to estimate a missing record at a streamgage of interest (Granato, 2009). The SREF program produces estimated daily mean streamflow for the purpose of extending or augmenting the streamflow record at streamgages with limited data (Granato, 2009). Record extension in SREF uses the line of organic correlation (LOC) regression as part of a maintenance of variance (MOVE) method. A valuable characteristic of the LOC for streamflow record extension is the prediction of flows with variance and probability distribution that can closely estimate those of the observed record (Helsel and Hirsch, 1992, p. 276-278). The MOVE.1 method (Hirsch, 1982, Vogel and Stedinger, 1985) was used for this analysis.

The streamflows were log transformed prior to LOC regression. This transformation resulted in undefined logarithms when zero-flow values were present. SREF offers four options to address zero flows in the streamflow record. Three of the options substitute constants for zero-flow days. The fourth option, and the one selected for this application, applies a streamflow-recession constant beginning with the last nonzero streamflow value prior to the zero-flow sequence. This procedure creates a series of streamflow values that decrease with each successive zero-flow day. This option was chosen to avoid imposing an arbitrary constant flow value over a potentially substantial period of low-flow values that would result in a flatline hydrograph for streamgages at their 




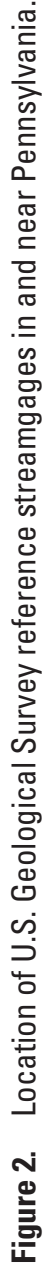




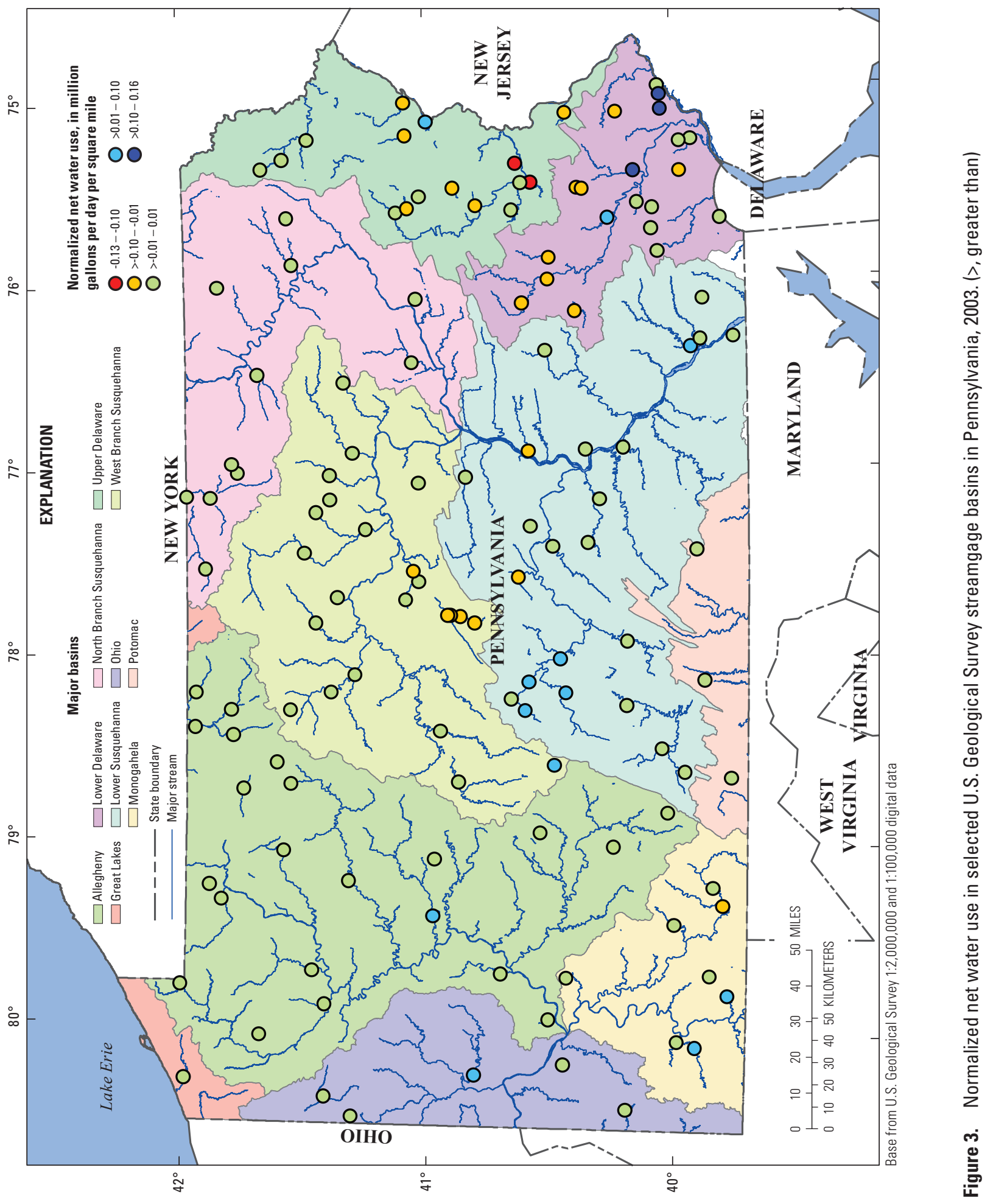


zero-flow threshold. For example, in an upstream-downstream pairing, streamflow at the downstream streamgage, although strongly correlated with the upstream streamgage, does not recede to zero flow as quickly or as often owing to a larger drainage area. The daily rate of decrease is determined by the streamflow-recession constant and ranges from 0 to 1 . On the basis of a sampling of low-flow recession rates for the reference streamgages, a recession constant of 0.9 was selected.

The streamgages used to extend the record of a streamgage with an incomplete period of record during WY 1960-2008 are termed "index streamgages." Ten years was considered the minimum streamflow record length for an acceptable application of MOVE.1. Eleven reference streamgages had 10-year periods of record of observed streamflows or less during WY 1960-2008. For those streamgages, a period of record from 1950 to 2008 was used to obtain the requisite 10 years of concurrent observed streamflows. After the streamflow record extensions were completed, records were trimmed back to the 1960 to 2008 period. A maximum of three streamgages was used for record extension (appendix 2). Selection of index streamgages was based on period of available concurrent record, strength of correlation, and distribution of LOC residuals. The concurrent records were evaluated graphically and statistically using correlations and the $\mathrm{R}^{2}$ statistic to ensure a good fit between the index streamgage and a streamgage with an incomplete period of record. Record extension correlations ranged from 0.75 to 0.98 , with a mean of 0.92. A listing of streamgages with record extension techniques applied is provided in appendix 2 .

\section{Regression Equations for Estimating Flow- Duration Exceedance Probabilities}

Regression equations were developed for 17 percentiles along the FDC using observed streamflow data from 162 of the 168 reference streamgages in Pennsylvania and surrounding states from the beginning of observed record through the 2008 WY (appendix 1). Values for basin characteristics with possible effects on a range of streamflow, such as land cover and soil properties, were determined for the streamgages, and exceedance probabilities were computed for the streamgages using the entire period of unregulated flow. The observed exceedance probabilities (dependent variable) were related to the basin characteristics (independent or explanatory variables) using regression techniques.

\section{Streamgages and Basin Characteristics Used in Regression Analysis}

Daily streamflow values for the selected streamgages were retrieved from the National Water Information System (NWIS) web application (http://waterdata.usgs.gov/ nwis) using the program Get NWIS WEB Streamflow Files
(GNWISQ) (Granato, 2009). This program allows for batch downloads from NWISweb and formats the retrieved files for further analysis. After the downloaded data were reviewed for completeness and accuracy, the data were entered into the Make Plotting Position File (MkPP) (Granato, 2009) to compute the flow-duration exceedance probabilities. The Weibull plotting position option was used. Only the period of record for observed unregulated flow at the streamgage was used to compute the exceedance probabilities for use in the regression analysis.

A list of 28 climatologic, geologic, hydrologic, and physiographic basin characteristics with possible effects on a range of streamflows was compiled from various geographic information system (GIS) sources (table 1). Only basin characteristics derived using GIS methods were evaluated during the regression analysis. The use of GIS-derived basin characteristics improves the consistency, reproducibility, and ease-of-use of the resulting regression equations. Many of the basin characteristics evaluated were used in previous regression analyses (Stuckey, 2006; Roland and Stuckey, 2008; Risser and others, 2008) and can be determined using the StreamStats web application for Pennsylvania (Stuckey and Hoffman, 2010).

\section{Regression Analysis and Resulting Flow- Duration Exceedance Probability Regression Equations}

The exceedance probabilities for observed streamflows were related to basin characteristics using exploratory ordinary least squares (OLS) and weighted least squares (WLS) regression techniques. The exceedance probabilities were weighted using the following expression for the WLS regression techniques to account for different periods of record: (number of years of record at streamgage $\times$ number of streamgages) / sum of years of record of all streamgages. Regression iterations were performed using the statistical package Spotfire S+ (TIBCO Software Inc., 2008). Regression diagnostics used to evaluate the resulting regressions include graphical relations, multicollinearity, prediction error sum of squares (PRESS) statistic, standard error, and coefficient of determination $\left(\mathrm{R}^{2}\right)$ (Helsel and Hirsch, 1992, p. 245-253; p. 300-315).

Data from 162 streamgages in and near Pennsylvania were used to develop regression equations for estimating the 1-, 5-, 10-, 15-, 20-, 30-, 40-, 50-, 60-, 70-, 80-, 85-, 90-, 95-, and 99-percent exceedance probabilities (P1, P5, P10, P15, P20, P30, P40, P50, P60, P70, P80, P90, P95, and P99, respectively). Two additional regression equations were developed for the 0.0056- and 99.9944-percent flow-duration exceedances (P0.0056 and P99.9944, respectively) to represent the ends of the FDC for the period from 1960 to 2008 (49 years). Because only observed data were used in the regression analysis, the streamgages used to develop the regression equations for the lower and upper ends of the FDC were limited to those with at least 49 years of record. As a result, 67 streamgages 
Table 1. Basin characteristics used in the development of regression equations for flow-duration exceedance probabilities for Pennsylvania streams.

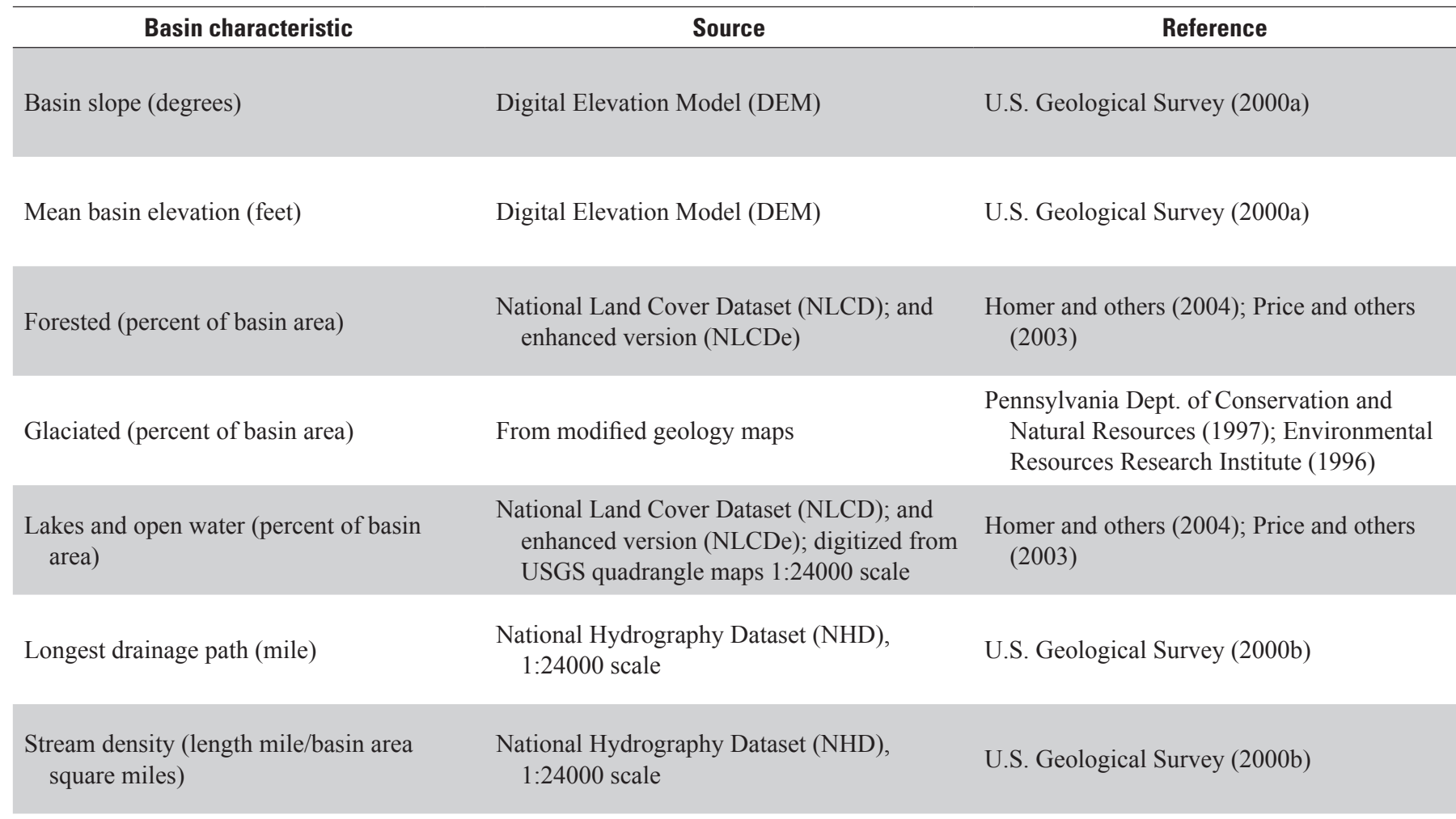
Channel slope (feet per mile)
Digital Elevation Model (DEM)
U.S. Geological Survey (2000a)

Soil infiltration index (unit less $1=$ well to 4=poor)

State Soil Geographic (STATSGO) database

U.S. Department of Agriculture (1994) Mean annual precipitation, 1971-2000
(inches)
Parameter-elevation Regressions on
Independent Slopes Model (PRISM)

Digital Elevation Model (DEM)
Daly (1996)

Drainage area (square mile)

State Soil Geographic (STATSGO) database

U.S. Department of Agriculture (1994)

Soil depth to bedrock (feet)

State Soil Geographic (STATSGO) database

U.S. Department of Agriculture (1994) to $7=$ poor)

Soil available water content (percent)

Soil permeability (inches per hour)
State Soil Geographic (STATSGO) database

U.S. Department of Agriculture (1994)
U.S. Geological Survey (2000a) 
Table 1. Basin characteristics used in the development of regression equations for flow-duration exceedance probabilities for Pennsylvania streams.-Continued

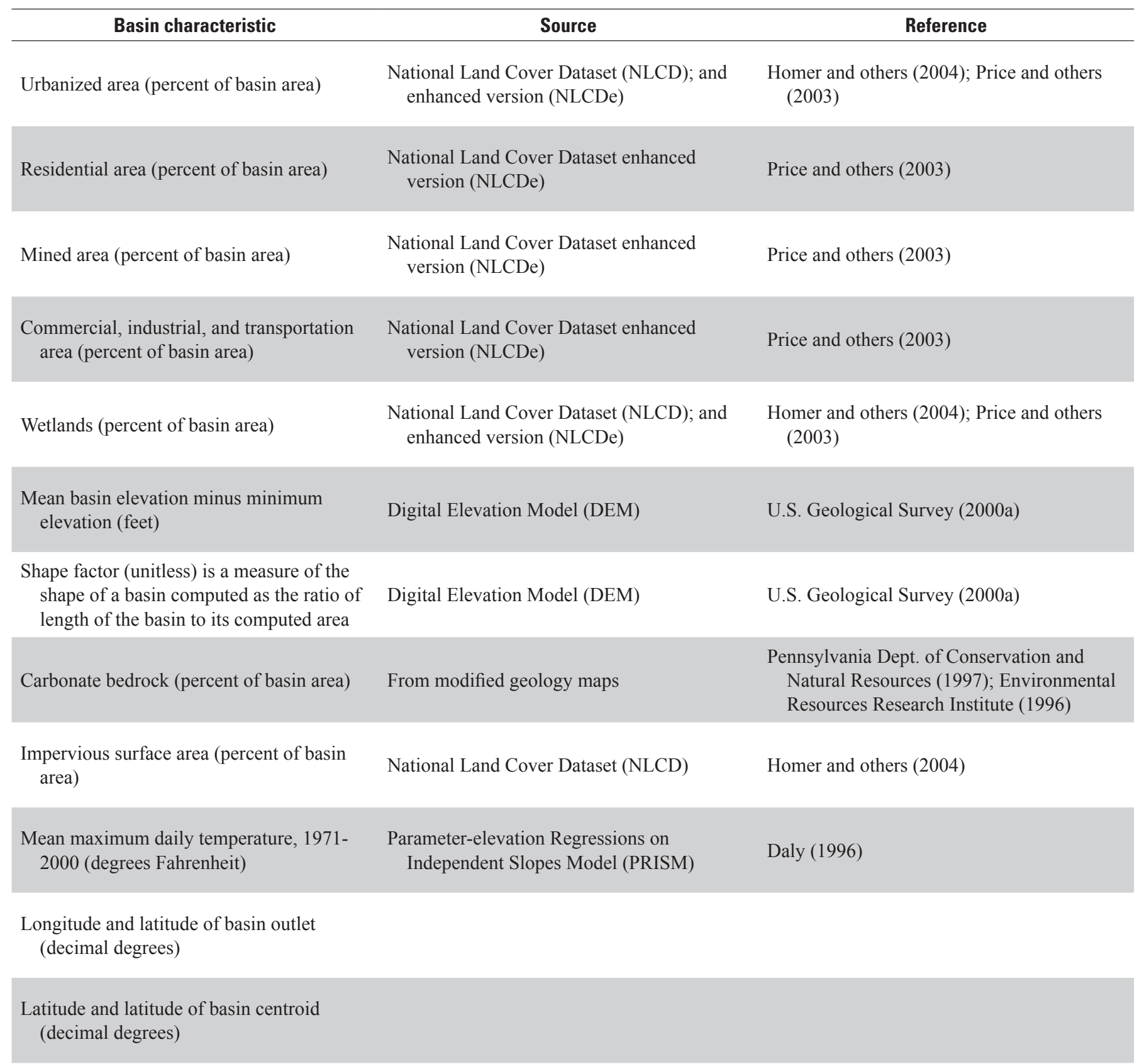


with sufficient period of record were used to develop regression equations for estimating the P0.0056 and P99.9944 exceedance probabilities. Outliers and streamgages with high leverage and (or) influence were removed from individual regression analysis only if sufficient data or information was found to support the removal of the streamgages, such as high water use in the basin (including withdrawals and discharges), abnormal basin characteristics or streamflow, or poor or estimated daily streamflow computations during low- or high-flow periods.

The possibility of dividing the State into regions was evaluated during exploratory regression analysis using OLS and WLS. Basic statewide regression equations were initially developed, and residual standard errors were mapped to determine if regionalization was appropriate. Although no pattern was observed in the residuals, previously defined low-flow and peak-flow regions (Stuckey, 2006; Roland and Stuckey, 2008) were used to regionalize the State during the exploratory regression analysis to possibly improve regression diagnostics. The resulting standard errors, coefficient of determination $\left(\mathrm{R}^{2}\right)$, residuals, PRESS statistic, and other regression diagnostics were compared to the statewide initial regression equations. The exploratory regressions resulting from using previously defined low-flow regions lowered the standard error of prediction for the lower exceedance probabilities but increased the standard error of prediction for the higher exceedance probabilities. There was no noticeable improvement in error when using the previously defined peakflow regions. The statewide regression equations consistently produced a range of the exceedance probabilities with more accuracy than regression equations using either set of regions. Also an attempt was made to create new regions on the basis of the statewide residuals, hydrologic unit code (HUC) 8 boundaries, physiographic provinces, and (or) major basins, but no overall improvement was noted. As a result, regression equations for the suite of exceedance probabilities were developed on a statewide scale. WLS was used to generate the final statewide regression equations.

The following independent variables were found to be significant at the 95-percent confidence level for one or more regression equations: longitude at the outlet, drainage area, mean annual precipitation, mean maximum daily temperature, depth to bedrock, drainage runoff number, and percentages of carbonate bedrock and impervious surface area (table 2). The basin characteristics values associated with the streamgages used in the analysis are listed in appendix 3 . To form a nearlinear relation between the flow-duration exceedance probabilities and basin characteristics, all independent and dependent variables were log-transformed (base 10) prior to regression analysis. Because percentages can have a value of zero, 1.0 was added to the decimal form of the percentages of carbonate bedrock and impervious surface area.
The regression model took the following form, in log units:

$$
\begin{aligned}
\log \widehat{Q} p= & A+b \log \text { Long }+c \log D A+d \log P p t+ \\
& e \log M a x T+f \log T h k+g \log \text { Drn }+ \\
& h \log (1+0.01 \times \text { Carb })+i \log (1+0.01 \times \operatorname{Imp})
\end{aligned}
$$

or in arithmetic space:

$$
\begin{aligned}
\widehat{Q} p= & 10^{A}(\text { Long })^{b}(\text { DA })^{c}(\text { Ppt })^{d}\left(\text { MaxT }^{e}(\text { Thk })^{f}(\text { Drn })^{g}(1+\right. \\
& 0.01 \times \text { Carb })^{h}(1+0.01 \times \operatorname{Imp})^{i},
\end{aligned}
$$

where

$$
\begin{aligned}
\log = & \text { log to base } 10 ; \\
\widehat{Q} p & =\text { flow-duration exceedance probability } \\
& \text { in cubic feet per second; } \\
A & \text { the intercept; } \\
\text { Long }= & \text { longitude of the outlet of the basin, } \\
& \text { in decimal degrees; } \\
D A= & \text { drainage area, in square miles; } \\
P p t= & \text { mean annual precipitation, in inches; } \\
\text { MaxT }= & \text { mean maximum daily temperature, } \\
& \text { in degrees Fahrenheit; } \\
\text { Thk }= & \text { soil depth to bedrock, in feet; } \\
\text { Drn }= & \text { drainage runoff number, unitless; } \\
\text { Carb }= & \text { basin underlain by carbonate bedrock, } \\
& \text { in percent; } \\
\text { Imp }= & \text { impervious surface area in basin, } \\
& \text { in percent; and }
\end{aligned}
$$

$b, c, d, e, f, g, h$, and $i=$ independent variable coefficients of regression estimated by WLS.

Standard errors of prediction for the regression equations provide an estimate of reliability of the predicted exceedance probabilities (table 2) (Helsel and Hirsch, 1992, p.35). The standard error of prediction for the flow-duration exceedance probability regression equation ranged from 0.05 to 0.34 in $\log$ units (11 percent to 92 percent; table 2); mean standard error over the entire suite of flow-duration equations equals 31 percent. The regression equations used to estimate the lower ends of the FDC have the highest errors; the extreme low-flow exceedance probability of P99.9944 has an error of 92 percent, and P99 and P95 have errors of 64 percent and 47 percent, respectively. For comparison, the most recent regression equations developed for estimating the 7-day, 10-year low flow for streams in Pennsylvania have errors ranging from 51 percent to 66 percent (Stuckey, 2006). The coefficient of determination $\left(\mathrm{R}^{2}\right)$ provides a way of estimating the uncertainty associated with the regression. For example, the $\mathrm{R}^{2}$ for P60 is 0.97 , indicating the basin characteristics selected for use in the P60 regression equation describe about 97 percent of the influence that all basin characteristics have on predicting the 60 -percent 


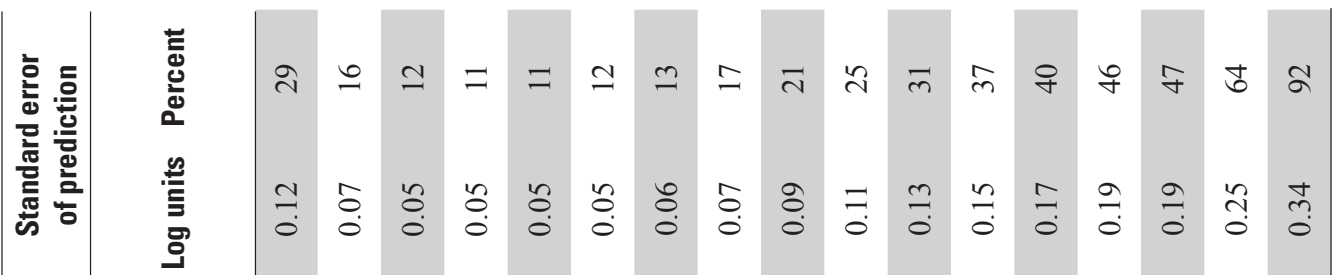

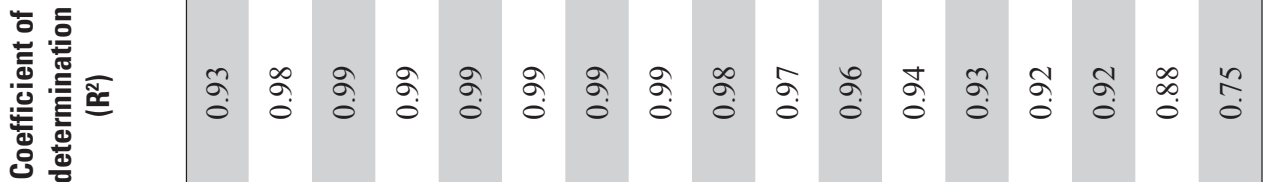

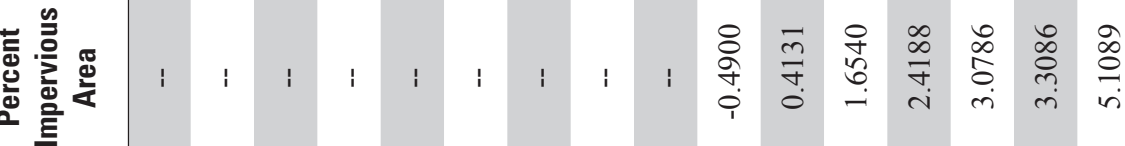

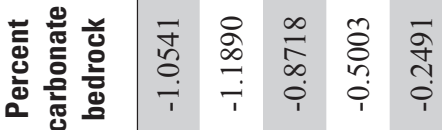

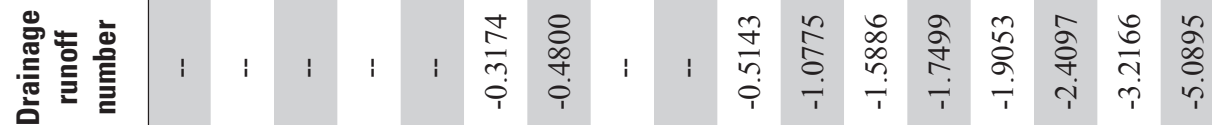

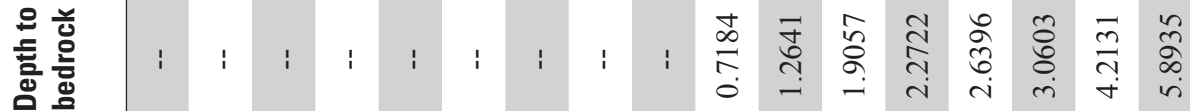

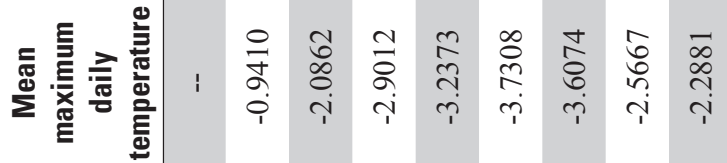

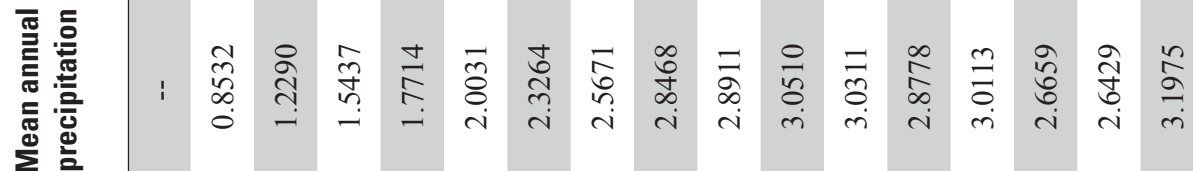

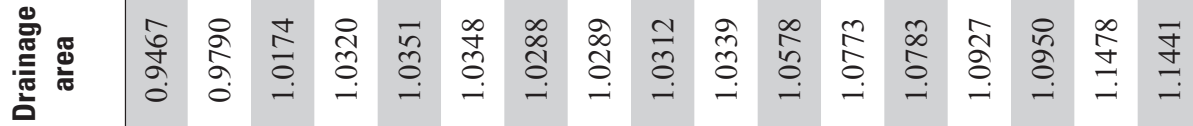

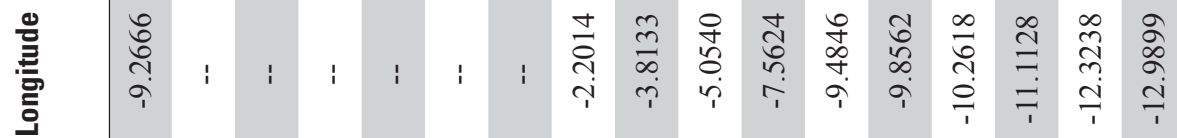

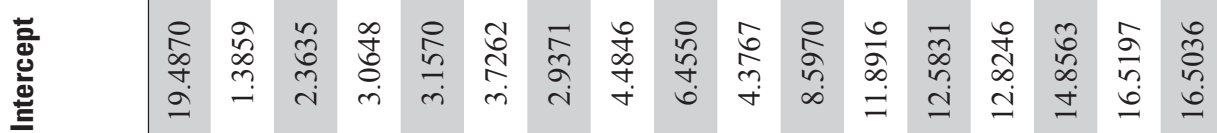

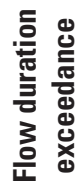

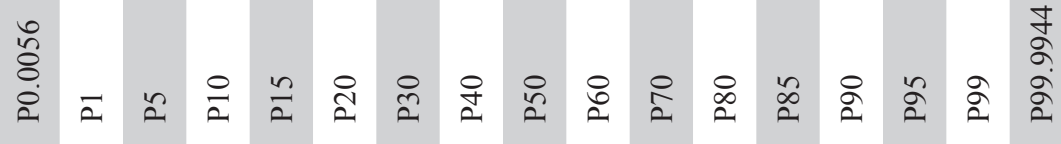


exceedance value (table 2). A lower $\mathrm{R}^{2}$ for P99.9944 (0.75) indicates that additional variables may help to better define this extreme low-flow prediction. Flow-duration exceedance probabilities computed from streamflow data (observed) and regression equations (predicted) for streamgages used in the regression analysis can be found in appendix 4 .

\section{Selection of Reference Streamgages for Estimating Baseline Daily Mean Streamflow}

An important consideration in applying the QPPQ method is the selection of a reference streamgage. A typical approach has been to select the closest reference streamgage to the ungaged location as the preferred reference gage. Choosing the closest streamgage as the most appropriate (best) reference streamgage is based on the assumption that similarity in the conditions determining streamflow increases with decreasing distance between two locations. However, there are many instances where conditions at the closest streamgage are neither physically or hydrologically similar to those at the ungaged location. Archfield and Vogel (2010) showed that the closest reference streamgage is not always the best choice and introduced the map correlation method as an alternative.

\section{Map Correlation}

Map correlation is a geostatistical approach to selecting a reference streamgage where streamflow exhibits the strongest correlation with that at an ungaged location. First, each reference streamgage is assigned a unique map of correlation estimate developed from a model of the spatial correlation structure, or variogram, between it and all other available reference streamgages in Pennsylvania and surrounding states (fig. 4). Ordinary kriging (Isaaks and Srivastava, 1989) is used to estimate the expected correlation at the ungaged location.

Selecting the most appropriate (best) reference streamgage is accomplished by choosing the streamgage whose map has the highest correlation coefficient at the coordinates of the ungaged location. Map correlation may be a unique application of geostatistical models in that many models need to be compared as part of the reference streamgage selection process. Selecting the best model is, therefore, dependent in part on all models being fit in a consistent manner to avoid biasing one or more models. Variogram model fitting can involve a substantial amount of trial and error (Isaaks and Srivastava, 1989; Archfield and Vogel, 2010) and subjectivity as well. When the models are fit interactively, it is likely to result in many parameters having few similarities. One model may perform better than another simply because more time was given to finding the best parameters. Considering the small differences in correlation coefficients among many reference streamgages, minimization of subjectivity in model fitting is an important consideration. In an attempt to minimize subjectivity, the variogram models were developed in the Geostatistical Analyst extension in ArcMAP 9.3 (Environmental Systems Research Institute, Inc., 2009) using default automated parameter estimation.

\section{Application of Map Correlation in Two Pilot Basins}

The map correlation method was originally developed using streamflow data from streamgages in and near Massachusetts and had not been previously tested for use in Pennsylvania. Because of this, the map correlation method was applied and evaluated for two pilot basins situated primarily in Pennsylvania (fig. 5) in anticipation of extending map correlation to the entire State and as a means of exploring possible improvements to the method. The objective of the pilot basin analysis was to compare the relative efficiency of the widely used closest streamgage method to the map correlation method as used by Archfield and others (2010) and to determine if modifications could improve the method's use in Pennsylvania. Pennsylvania is hydrologically diverse, in large part, because of its varied geology and topography. The first pilot basin, Lower Susquehanna River Basin, is located in southcentral Pennsylvania and northern Maryland and is bounded by HUC 020503 . The Lower Susquehanna River Basin covers approximately 9,200 square miles $\left(\mathrm{mi}^{2}\right)$ in the Susquehanna River Basin. Twenty USGS streamgages within HUC 020503 were selected as reference gages (table 3 ). The second pilot basin, the Upper Delaware River Basin, is bounded by HUC 020401 and drains approximately $6,900 \mathrm{mi}^{2}$ of the Delaware River Basin in parts of New York, New Jersey, and Pennsylvania. Eighteen reference streamgages were selected within HUC 020401 (table 3). The reference streamgages selected had minimally altered hydrology from human activities. The period of available daily streamflow record ranged from 13 to 59 years.

The modifications to Archfield and others (2010) method, applied for the pilot basins in Pennsylvania, include (1) using Spearman's rho in place of Pearson's $r$ for streamflow correlations, (2) using basin centroid locations in place of basin outlet locations when defining correlation models, and (3) adding anisotropy parameters to the correlation models. For this analysis, anisotropy is measured by observing the directional orientation in the shape of stream basins and stream channels.

\section{Correlation Metrics}

The map correlation method defines a spatial correlation structure of daily streamflow among a set of reference streamgages. Archfield and others (2010) chose Pearson's $r$ of the logarithms of daily streamflow at reference streamgages as the correlation metric. Pearson's $r$ is a parametric measure of the linear association between two variables (Helsel and Hirsch, 1992, p.218-219). It assumes a bivariate normal distribution, is sensitive to outliers, and is insensitive to strong associations that are nonlinear. Daily streamflow data generally follow a lognormal distribution, and taking the logarithms prior to computing Pearson's $r$ improves the results as Archfield and others (2010) noted. 


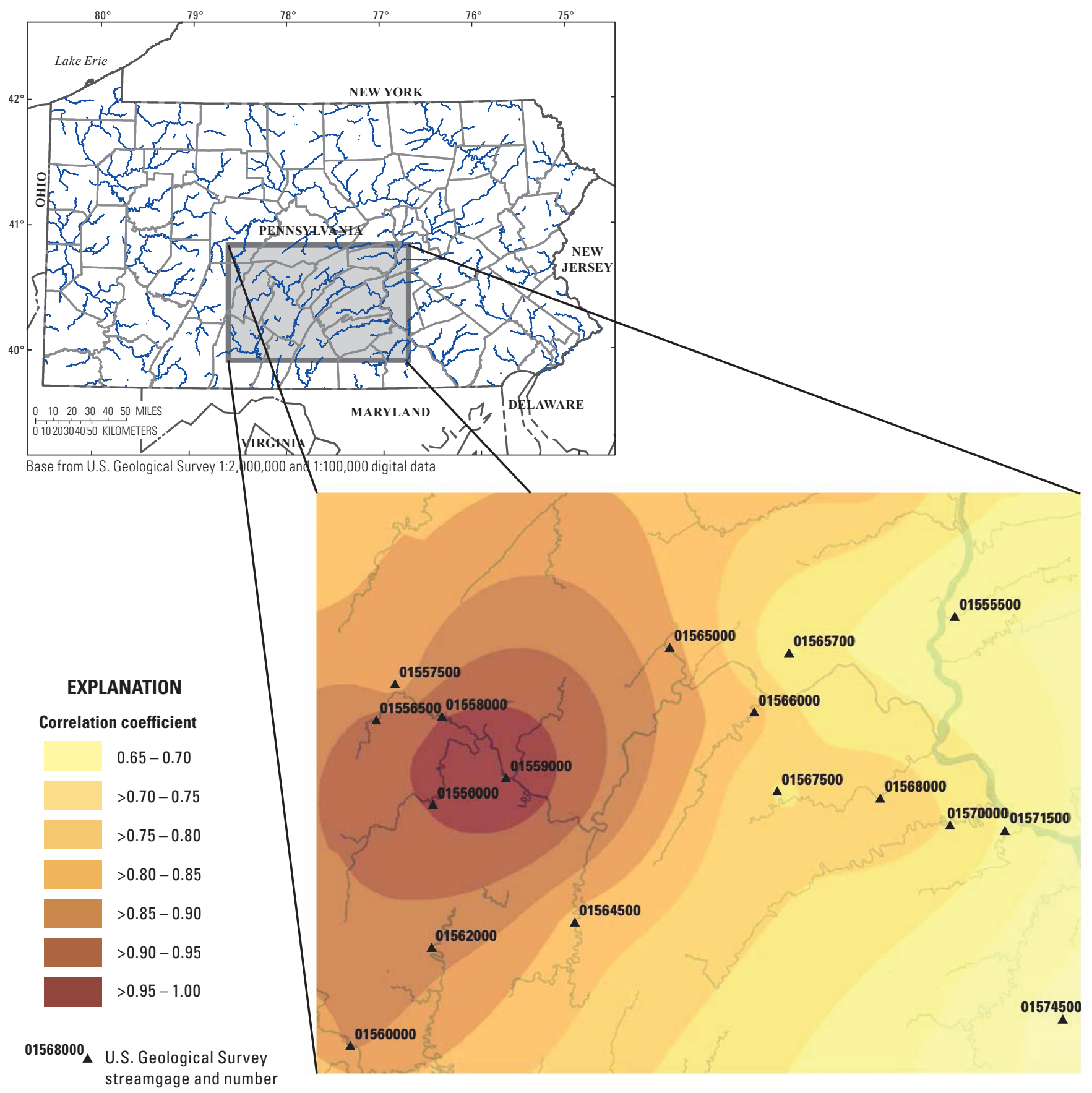

Figure 4. Example correlation map for U.S. Geological Survey streamgage 01559000, Juniata River at Huntingdon, Pa. (>, greater than) 


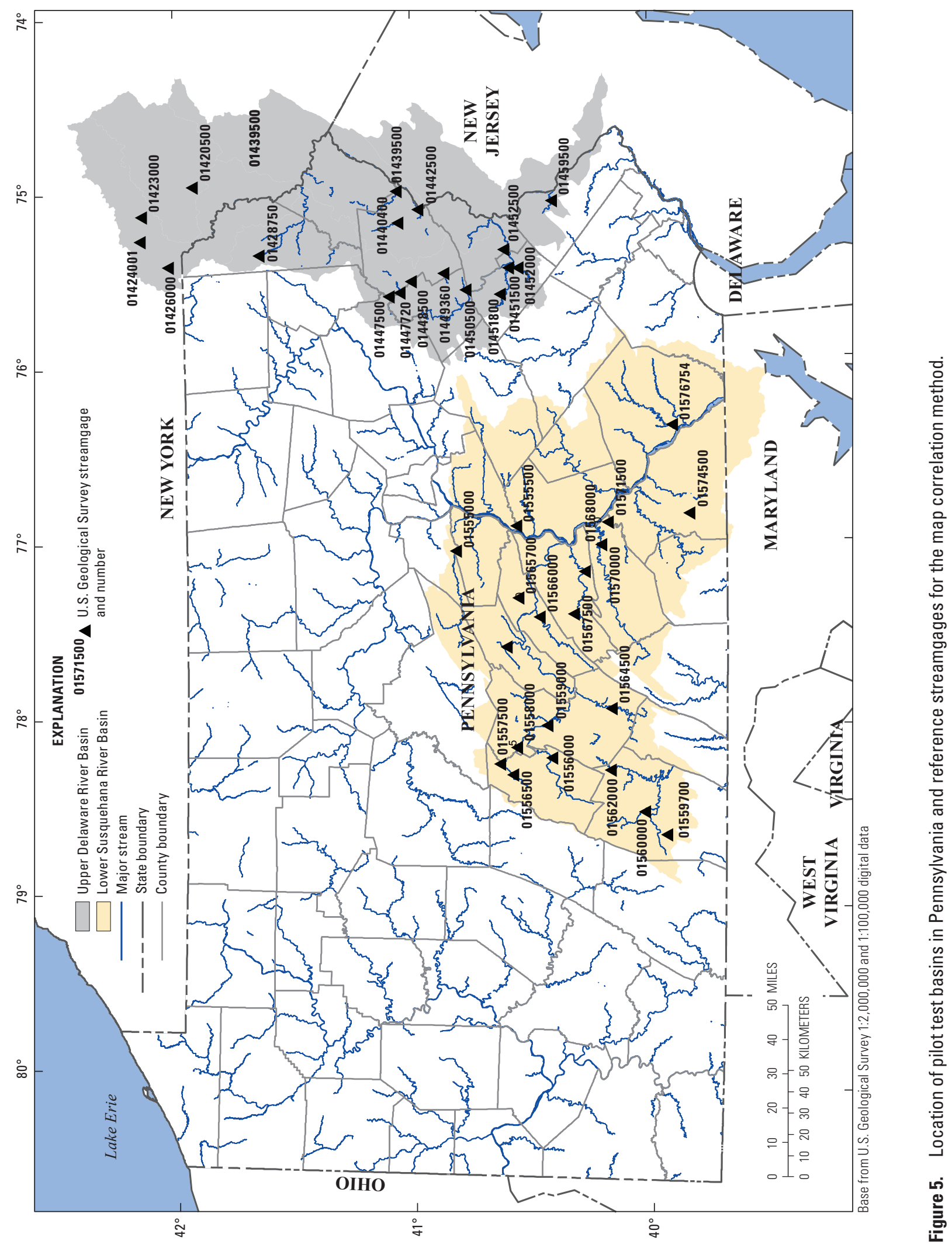


Table 3. Description of selected U.S. Geological Survey reference streamgages in the Upper Delaware River Basin and the Lower Susquehanna River Basin in Pennsylvania.

[ddmmss, degrees, minutes, seconds; $\mathrm{mi}^{2}$, square miles]

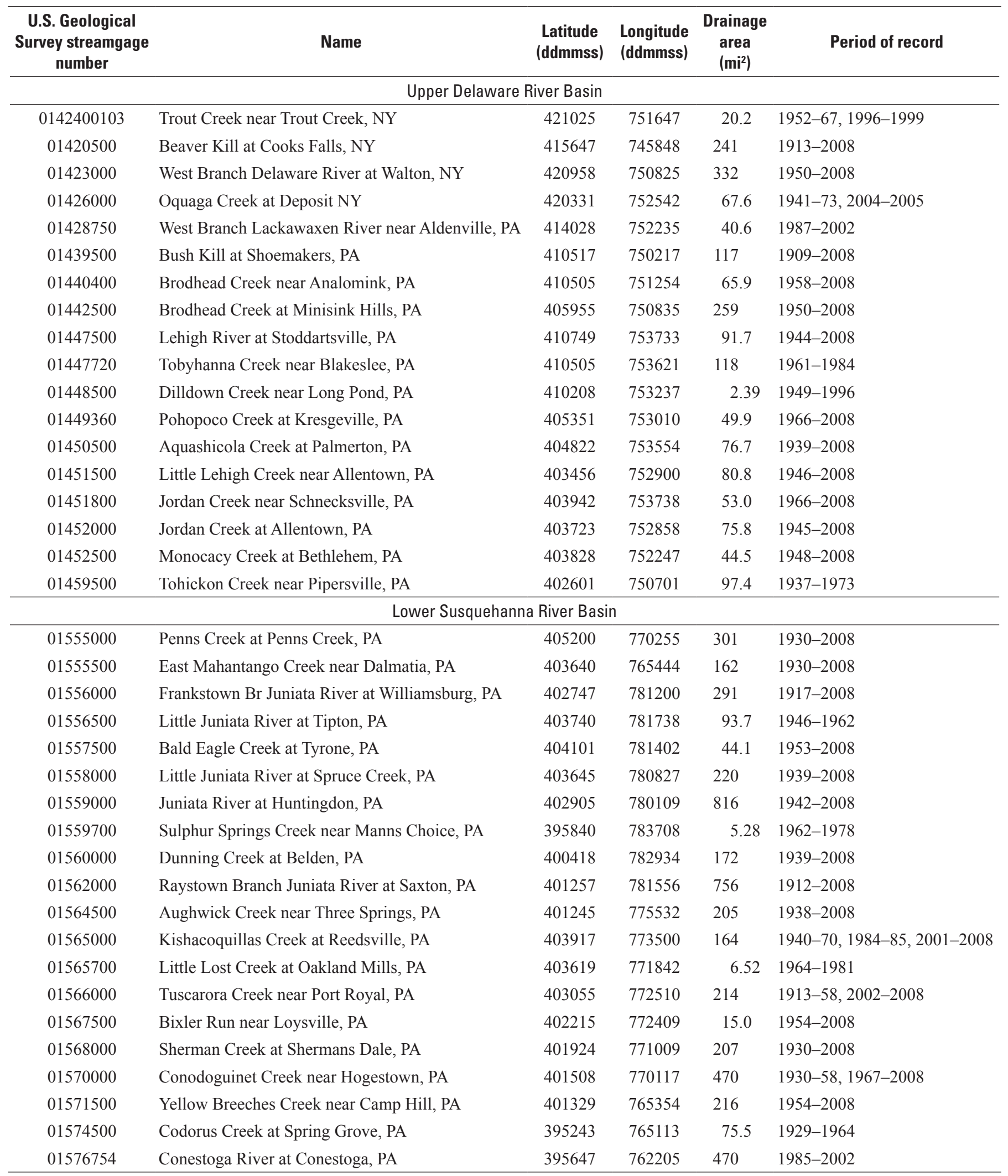


Although it is straightforward to compute Pearson's $r$ of the logarithm of streamflow, Pearson's $r$ for several reasons may not be an optimal choice when the map correlation method is used in conjunction with the QPPQ method. First, measuring the correlation of FDC percentiles directly may improve the results. When applied as part of the QPPQ method, the Pearson's $r$ correlation of log transformed streamflow functions acts as a surrogate for the correlation of FDC percentiles between the ungaged and reference gage locations. The QPPQ method relies on the assumption of equivalence of percentiles between an ungaged location and a reference streamgage (Waldron and Archfield, 2006) and measures equivalence in the relation between streamflows.

Second, Pearson's $r$ is a measure of a linear association (Helsel and Hirsh, 1992, p. 218-219) and daily mean streamflow seldom fit a log normal distribution exactly. Records from different streamgages often yield non-linear correlations with a poor Pearson's $r$. The relation between streamflow at different streamgages does not need to be linear, but can have a strong rank-based correlation. FDCs are typically built around rank-based quantiles (Vogel and Fennessey, 1994; Helsel and Hirsch, 1992). In many instances FDC exceedance values are calculated using a formula derived from the general form

$$
p=(i-a) /(n+1-2 a),
$$

where

$$
\begin{aligned}
p & =\text { flow-duration exceedance probability } \\
i & =\text { rank of an observation } \\
a & =\text { constant, and } \\
n & =\text { number of observations. }
\end{aligned}
$$

Given that $a$ and $n$ are constants for a specific FDC, $p$ will retain the rank order of the observations. As a result, the association between FDCs is equivalent to a streamflow rankorder correlation.

A third issue is the occurrence of undefined logarithms when zero streamflow values are present. A common but less than desirable work-around is replacing the undefined logarithms with a small value. For the pilot basin analyses, 0.001 cubic feet per second was substituted for zero streamflow values when computing logarithms. Archfield and Vogel (2010) reported that Kendall's tau, a non-parametric rankbased correlation coefficient, could be used as alternative to Pearson's $r$ in areas with zero streamflow values, therefore, eliminating undefined logarithims. Although Kendall's tau is widely applied in hydrology, Spearman's rho is another non-parametric measure of correlation that can be used. Spearman's rho is similar in derivation and scale to Pearson's $r$, whereas Kendall's tau yields a smaller coefficient for most correlations (Helsel and Hirsch, 1992, p. 212-218). Although both Kendall's tau and Spearman's rho handle zero streamflow values and monotonic associations, they present different fits to the data. During exploratory analysis, it was found that Spearman's rho exhibits a more linear association with distance than Kendall's tau when the value is greater than about 0.7. A linear correlation to distance relation is advantageous when fitting a variogram model of the spatial correlation.

\section{Distance Metrics}

Archfield and Vogel (2010) applied ordinary kriging with a spherical variogram model to estimate cross-correlations of daily streamflows between a reference streamgage and ungaged locations anywhere within a study area. Those estimates are based on Euclidean distances between basin outlets (streamgage locations) at the reference and ungaged locations. Huang and Yang (1998) and Skoien and Blöschl (2007) use the centroid of the basin area for distance measures. They note that streamflow at a basin outlet actually represents local streamflows integrated over the entire basin area and imply that the centroid location better represents the basin area. Centroid distances were examined and compared for their performance in identifying the best reference gage in the map correlation method.

\section{Anisotropy}

The directional orientation observed in the shape of stream basins and stream channels is "anisotropy" and can be mirrored in the correlation of streamflow at streamgages located in the basin. Streamgages located along the same reach share the same directional orientation and exhibit higher magnitudes of correlation between streamflow and persistence of correlation with distance than streamgages located on different reaches. Streamgages on tributaries intersecting the mainstem in an orthogonal orientation are more likely to include independent tributary streamflow or streamflow similar to that of an adjacent basin. To determine if anisotropy information would improve selection of the best correlated reference streamgage, an anisotropy component was added to the spatial correlation models. Spatial correlation models with and without anisotropy were compared to determine whether the inclusion of anisotropy improved map correlation in the pilot basins.

Anisotropy parameters were used to define a set of orthogonal major and minor axes whose orientation and magnitudes were best fit to corresponding orientation-dependent variations in the correlation variograms. The Upper Delaware River and Lower Susquehanna River pilot basins trend north to south and west to east, respectively. Moreover, the length to width ratio and streamflow patterns are quite different. For example, the Upper Delaware River pilot basin is four times longer than wide, and the mainstem and major tributaries have prominent north to south components (fig. 5). The Lower Susquehanna River pilot basin is approximately two times longer than wide. Although there is an overall west to east orientation, there is great variation in reach orientation, and many of the tributaries flow in opposing directions. These characteristics indicate stronger anisotropy in the Upper Delaware River pilot basin than in the Lower Susquehanna River pilot basin. 


\section{Analysis and Results of Map Correlation in Two Pilot Basins}

The process of selecting the best reference streamgage using map correlation in the pilot basins treated each reference streamgage as an ungaged location using a leave-oneout cross-validation procedure. Each reference streamgage was removed, in turn, from each variogram dataset, and the correlation was estimated for that location. In this way, each reference streamgage location represents a sample ungaged location. The variogram model whose origin was the sample ungaged location was dropped from consideration. Thus, each reference streamgage location yielded $n-1$ correlation estimates, where $n$ is the number of reference streamgages.

The pilot basin analysis was intended to answer two questions. First, how well did the various map correlation models reproduce the correlation coefficients for the reference streamgages? Second, how successful was map correlation in picking the most correlated reference streamgage? These questions were examined during the multiple trials of map correlation and modifications for the pilot basins.

Direct comparison of the correlation coefficients among the trials was not feasible because of computational differences in $r$ and $r h o$. Therefore, the Nash-Sutcliffe (NS) efficiency value, suitable for comparisons across the different correlation coefficient types, was used. The NS efficiency value ranges from negative infinity to 1 . A perfect prediction of the observed data yields an efficiency of 1 . An efficiency of 0 indicates predictions no better than the mean of the data. A negative efficiency implies the data mean is a better predictor than the modeled data because of lower variance. Considering that all correlation maps need to perform similarly if the best reference streamgage is to be selected consistently, it follows that the trial with the highest average and lowest range in efficiencies is preferred.

NS efficiencies for the Lower Susquehanna River pilot basin correlation maps were not markedly different among the various trials (fig. 6). Median NS efficiencies ranged from 0.57 to 0.63 . Higher efficiencies were observed when the basin centroids rather than basin outlets were used to identify reference streamgage locations. Neither Pearson's $r$ nor Spearman's rho correlations performed consistently better. Map correlation using Spearman's correlation, in combination with basin centroid locations and anisotropy, had the highest median and smallest range in efficiency, except for a single outlier.

NS efficiencies for the Upper Delaware River pilot basin were generally lower than those for the Lower Susquehanna River pilot basin (fig. 6). Median NS efficiencies ranged from 0.27 to 0.69 . An efficiency advantage was not observed for either basin outlet or basin centroid locations. Pearson's and Spearman's correlations performed similarly well. Anisotropy, however, when used with basin centroids resulted in a substantial improvement in efficiencies. Both Pearson's $r$ and Spearman's rho correlations with basin centroid distance yielded nearly identical median efficiencies of 0.69 and 0.67 when combined with anisotropy.

The other question associated with the pilot basin analysis is: How successfully did the map correlation method select the most highly correlated streamgage? An initial assumption was that higher NS efficiencies would indicate improved chances of selecting the best correlated reference streamgage. Higher efficiencies indicate correlation map estimates are closer to the observed data. The best correlated reference streamgage was determined for each ungaged location by

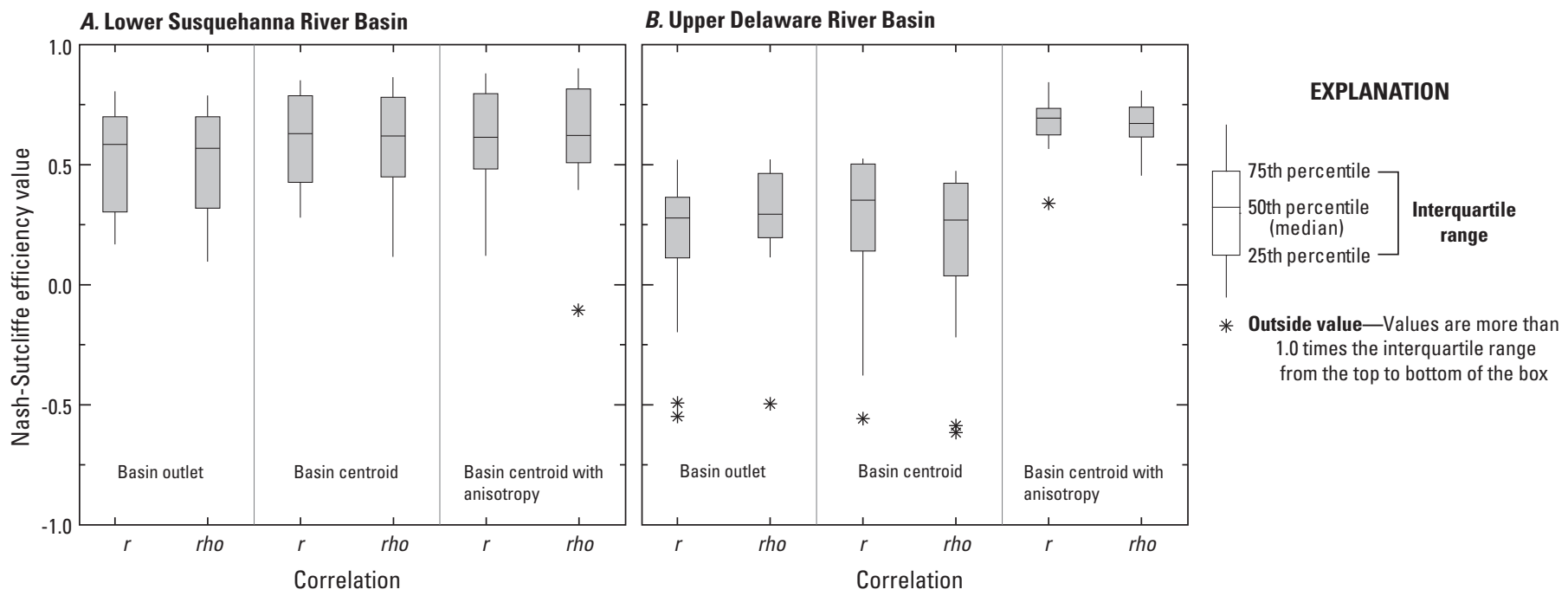

Figure 6. Distribution of Nash-Sutcliffe efficiency values computed from observed and estimated correlations of daily mean streamflows at selected U.S. Geological Survey streamgages in, $A$, the Lower Susquehanna River Basin and, $B$, the Upper Delaware River Basin in Pennsylvania. (r, Pearson's correlation; rho, Spearman's correlation) 
selecting the highest correlation value from among all crossvalidation estimates for a selected ungaged location. The percentage of time during the map correlation method trials that the best correlated streamgage was selected is presented in figure 7 along with two closest reference streamgage selection methods.

Success rates for selection of the best correlated reference streamgage in the Lower Susquehanna River pilot basin ranged from 25 to 60 percent (fig. 7). Map correlation performed better than other selection methods when basin centroids, Spearman's correlation, and anisotropy were used. Selection of the closest reference streamgage by basin outlet was the least successful, but substituting closest basin centroids for basin outlet locations improved the outcome by almost double. This trial essentially matched the success rate of map correlation using basin centroids. Basin centroids consistently improved selection results, whereas the choice of Pearson's $r$ or Spearman's rho did not. The addition of anisotropy for centroid-based correlation maps increased the success rate for selecting the best correlated reference streamgage when using Spearman's rho, whereas use of Pearson's $r$ led to a decrease in success rate. In general, the success rate for selecting the best correlated streamgage increased with an increase in the NS efficiency.

The Upper Delaware River pilot basin trials showed minimal differences in the success rates for selection of the best correlated reference streamgage. Success rates ranged from 50 to 61 percent across all trials (fig. 7). Selection of the closest

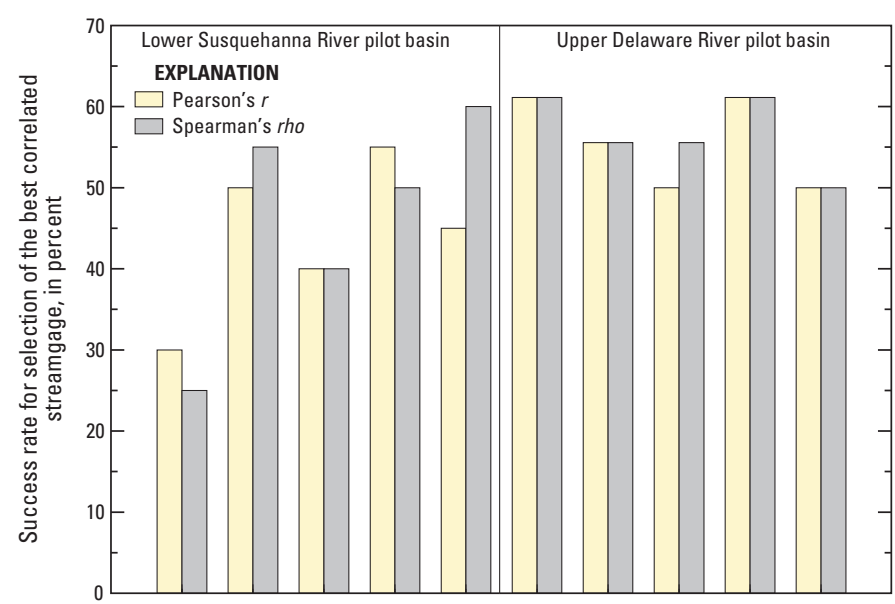

COUTL CCTRD MOUTL MCTRD MANIS COUTL CCTRD MOUTL MCTRD MANIS

Figure 7. Success rate for selection of the best correlated streamgage by using distance and map correlation methods applied in the pilot basins. (COUTL, closest streamgage using outlet distance; CCTRD, closest streamgage using centroid distance; MOUTL, map correlation using outlet distance; MCTRD, map correlation using centroid distance; MANIS, map correlation with anisotropy using centroid distance) reference streamgage by basin outlet location and map correlation selection using centroid location performed best, with a success rate of 61 percent. Using the basin centroid distance metric improved the map correlation selection outcome, but the rate of successful selection decreased when basin centroid was substituted for outlet location in the closest streamgage selection method. In only one trial (map correlation selection using basin outlet locations) did the choice of Pearson's $r$ or Spearman's rho have an effect on the success rates. Anisotropy reduced the success rate of map correlation using basin centroids from 61 to 50 percent. For the Lower Susquehanna River pilot basin, there was no clear association between the NS efficiencies and success rates for selecting the best correlated streamgage. This can be seen in the map correlation with anisotropy trials where NS efficiencies have the highest values of all trials (fig. 6), yet have the lowest success rates in selection of the best correlated reference streamgage.

The pilot basin trials demonstrate that modifications to the map correlation method of Archfield and others (2010) can improve the probability of selecting the most highly correlated streamgage as a reference streamgage for an ungaged location. The results from the trials in the two basins are summarized in table 4. The modified map correlation method performed as well as, or better than, the commonly used method of selecting the closest streamgage as a reference. The most useful modification is use of the basin centroid in place of basin outlet when determining distances in the correlation models, which consistently improved selection outcomes. Although the inclusion of anisotropy in map correlation improved selection outcomes in only one of the trials in the Lower Susquehanna River Basin, this may be an area for exploration in the future.

\section{Statewide Map Correlation Development}

Variogram models were developed for 156 reference streamgages in and near Pennsylvania with minimally altered streamflow and at least 10 years of continuous record during 1960-2008 water years and for 1 reference streamgage with 8 years of record that was selected to improve spatial coverage. The streamgages used in the map correlation development are listed in appendix 1 and labeled MAP. From the complete list of reference streamgages found in appendix 1, 12 of the streamgages were not included in the map correlation development because of insufficient unregulated streamflow record, insufficient streamflow record during 1960-2008, or invalid correlations related to limited concurrent years of record.

The spherical variogram model was selected to describe the spatial structure within the correlation of daily streamflow for several reasons. First, out of several model forms, it produced the best fit to the data. Additional trial fitting using exponential and Bessel function models was also explored. The trials confirmed that the spherical form produced the best fits averaged for all reference streamgages. Second, the spherical model exhibited a good match to the correlation to separation distance relation of the observed data at distances near the 
Table 4. Summary of map correlation application in two pilot basins in Pennsylvania.

[--, not applicable]

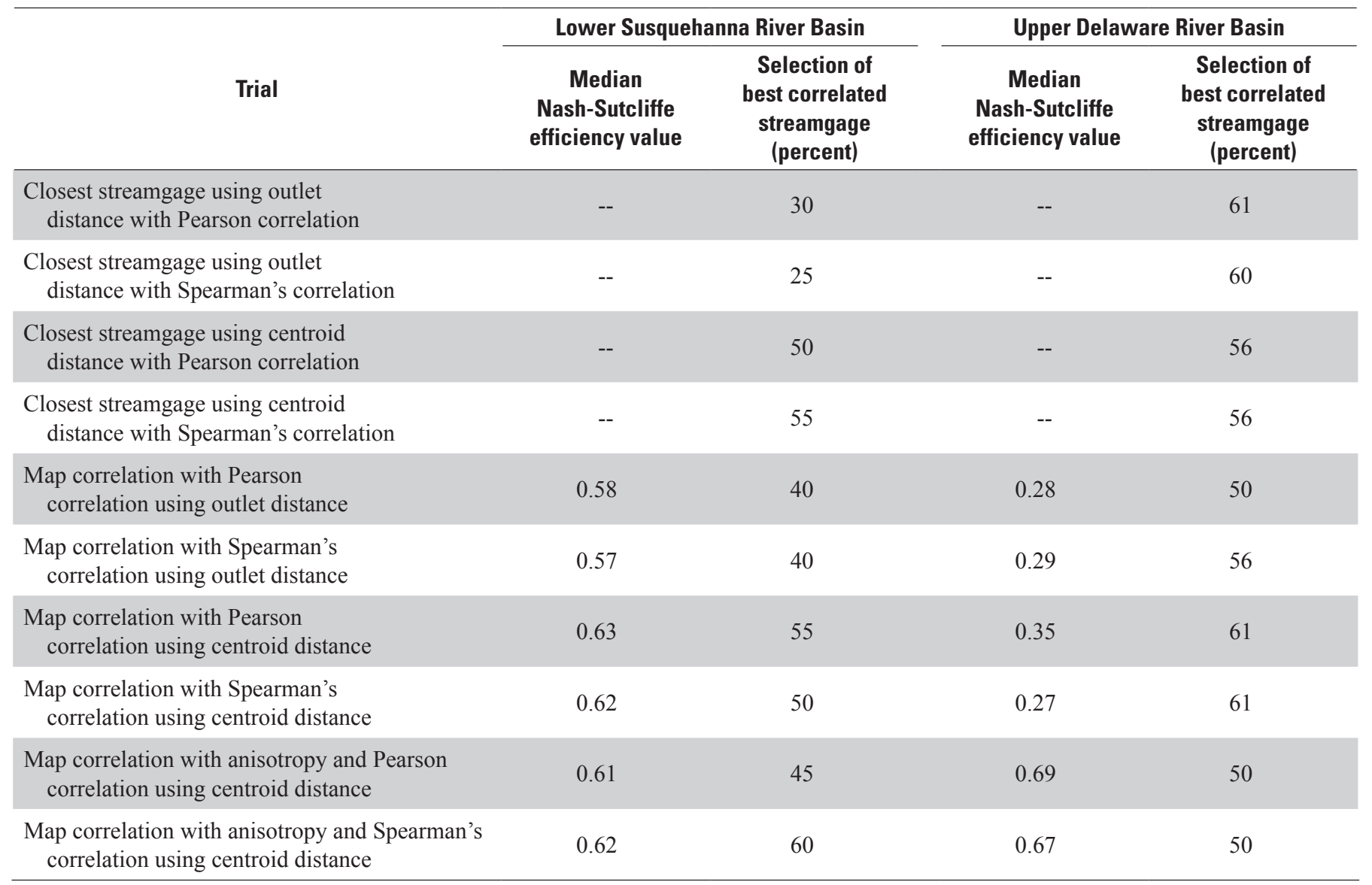

origin. Although not strictly equivalent, the variogram and the correlation to separation distance relation of the observed data in this application are similar in their representation of spatial continuity. Model fit is improved where there is similarity between the linear form of the spherical model near the origin and the correlation to distance relation of the observed data. The near origin behavior is an important consideration in the choice of model (Isaaks and Srivastava, 1989), and Pearson's $r$ and Spearman's $r h o$ for the reference streamgages have reasonably linear relations with distance, critically in the region nearest the origin. Lastly, the spherical model is perhaps the most broadly applied variogram function.

It is desirable that the period of streamflow record common to the reference streamgages be sufficiently long to represent as broad a range of streamflow values as possible. Short common periods of record can produce misleading correlation coefficients which may affect the spatial correlation relation and the choice of reference streamgage. Streamflow records of short duration often exhibit a restricted range of streamflows and are candidates for deletion from the dataset owing to limited usefulness for estimating a representative hydrograph for
20 years or more. As a practical matter, retaining these short period of record correlation pairs was deemed useful because the performance of map correlation (kriging) is contingent on data density (Archfield and Vogel, 2010; Skoien and Blöschl, 2007), and data obtained from short common periods of record have value for defining the spatial correlation structure. All reference streamgage correlations used in the variogram development were significant at the 0.05 level.

The mean correlation resulting from the map correlation method for the reference streamgages statewide is 0.93 (table 5). Mean correlations are shown in table 5 by drainage area and major basin. As the drainage area of the gaged basins increases, the mean correlation increases as well. Basins with small drainage areas tend to have unique hydrologic characteristics that can be more difficult to correlate with other basins. Lake Erie/Genesee River Basin had the lowest mean correlation, most likely because of the limited number of streamgages and lower density of streamgages than in other parts of the State. The Lower Susquehanna and Upper Delaware River Basins, in which the pilot analyses were conducted, had mean correlations of 0.94 and 0.95 , respectively. 
Table 5. Mean streamflow correlations for reference streamgages used in the map correlation method for Pennsylvania streams, by drainage area and major basin.

\begin{tabular}{lcc}
\hline \multicolumn{1}{c}{ Area/basin } & $\begin{array}{c}\text { Number of } \\
\text { reference } \\
\text { streamgages }\end{array}$ & $\begin{array}{c}\text { Mean } \\
\text { streamflow } \\
\text { correlation }\end{array}$ \\
\hline \multicolumn{2}{c}{ By drainage area (in square miles) } \\
\hline Less than 15 & 29 & 0.91 \\
15-49 & 23 & 0.93 \\
50-149 & 39 & 0.94 \\
150-499 & 49 & 0.95 \\
Greater than or equal to 500 & 16 & 0.96 \\
\hline & 18 & 0.95 \\
\hline Upper Delaware & 20 & 0.94 \\
Lower Delaware & 15 & 0.93 \\
Upper Susquehanna & 23 & 0.96 \\
West Branch Susquehanna & 20 & 0.94 \\
Lower Susquehanna & 7 & 0.92 \\
Potomac & 2 & 0.88 \\
Lake Erie/Genesee & 28 & 0.94 \\
Allegheny & 11 & 0.93 \\
Monongahela & 12 & 0.92 \\
Upper Ohio & 156 & 0.93 \\
Statewide & & \\
\hline
\end{tabular}

\section{Use of BaSE for Estimating Baseline Daily Mean Streamflow for Ungaged Locations}

The Baseline Streamflow Estimator (BaSE) is a tool for simulating minimally altered streamflow at a daily time step for an ungaged location in Pennsylvania for WY 1960 to 2008. BaSE is a user-friendly and time-saving tool used to assist water-resource managers in determining water-allocation, ecological-flow, and human-health needs. BaSE is modeled after the MASYE (Archfield and others, 2010), but parts of the MASYE code have been modified for use in this application and written as a stand-alone application on a visual basic.net (VB.NET) platform with the use of Microsoft Excel®). Output from the program consists of reference streamgage information, baseline daily mean streamflow, mean and median streamflow, FDCs, and hydrographs.

Basin characteristic information for the ungaged location is manually entered by the user or obtained in StreamStats (http://water.usgs.gov/osw/streamstats/pennsylvania. $h t m l)$. BaSE can read in the geodatabase file downloaded from StreamStats and auto-populate the opening screen with the required information. BaSE selects an appropriate reference streamgage for a user-entered ungaged location by default; the default is based on maximizing the estimated streamflow correlation. The user has the option of manually selecting a different reference streamgage. After the initial information is entered into BaSE, the Compute Baseline Daily Streamflows function computes the baseline daily mean streamflows for the ungaged location for WY 1960 to 2008.

A report output file, a Microsoft Excel $®$ spreadsheet, is generated and summarizes the reference streamgage and ungaged location information, including basin characteristics, percent difference in basin characteristics between the two locations, and any warnings associated with the basin characteristics (fig. 8). Mean and median streamflows are computed for the ungaged location. FDCs and hydrographs are presented for the ungaged location in cubic feet per second and cubic feet per second per square mile. The estimated daily flows for the ungaged location can be easily exported to a text file that can be used as input into a statistical software package to determine additional streamflow statistics, such as low-flow frequencies or monthly flow-duration exceedance probabilities. More detailed information, instructions for use, and all related links to files for the BaSE tool are in appendix 5.

\section{Accuracy and Limitations of Estimated Baseline Streamflows}

Accuracy of estimated baseline daily streamflows for ungaged locations is dependent on the uncertainties associated with the multiple steps which compose the overall process. These steps include (1) measurement of streamflow at reference streamgages, (2) streamflow record extension at reference streamgages, (3) selection of a reference streamgage using the map correlation method, (4) transfer of exceedance probabilities from reference streamgage to the ungaged location, and (5) estimation of the flow duration curve for an ungaged location on the basis of regression equations and basin characteristics.

The accuracy of measured streamflow data is documented for each reference streamgage in annual data reports. In Pennsylvania, most of the published streamflow records are rated as fair to good. These ratings specify that 95 percent of the data are within 10 (good) to 15 (fair) percent of their true values.

Streamflow record extension introduces uncertainty to baseline streamflow estimates, which is difficult to quantify. Because the length of record requiring extension varied by streamgage from none to 75 percent of the record, the uncertainty introduced to the overall record also varies. A general sense of the accuracy of these estimates can be obtained by observing the correlation coefficients, which range from 0.75 to 0.98 (with a perfect correlation equal to 1 ). Factoring in the part of the record that required no extension will decrease the overall uncertainty. When the relation between the logarithm of streamflow at a streamgage requiring record extension and 


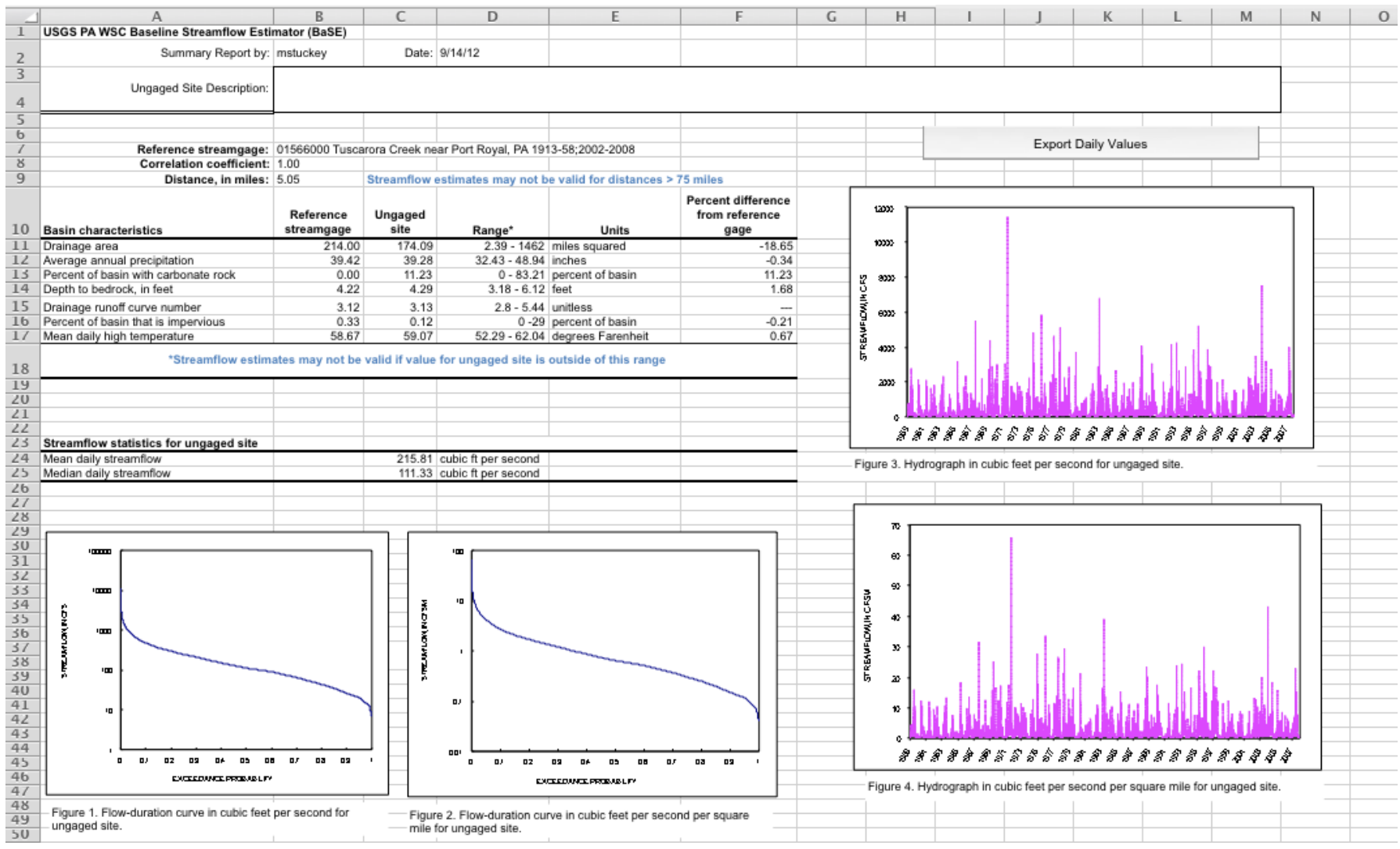

Figure 8. Screen capture of report generated by the BaSE tool showing flow duration curves and a hydrograph.

the logarithm of streamflow at the reference streamgage is non-linear, the correlations, and associated uncertainties, are less likely to agree. Thus, the overall uncertainty introduced by record extension is a combination of the length of extension period, strength of reference streamgage correlation, and quality of the relation between daily streamflow and daily exceedance probabilities when streamflow is used as a surrogate for exceedance probability

The selection of a reference streamgage by map correlation affects the uncertainty in the baseline streamflow estimates by way of the accuracy with which the best correlated reference streamgage is selected. Even when the best correlated reference streamgage is selected, uncertainty is introduced into the daily exceedance probabilities for the ungaged location because the reference streamgage would still not be perfectly correlated. Additional uncertainty would be introduced if map correlation did not select the best correlated reference streamgage. In the pilot basin trials, crossvalidation experiments permitted comparison of the accuracy between the map correlation methods and alternate means in the selection of the best reference streamgage. The pilot basin trials showed that 50 to 60 percent of the time, map correlation selected the best correlated streamgage. However, the accuracy of map correlation when extrapolated to ungaged locations across Pennsylvania remains unknown.

The transfer of streamflow exceedance probabilities from reference streamgage to an ungaged location relies on the assumption that both locations experience identical exceedance probabilities at identical times. Although this assumption is more likely to be true for locations in proximity to the reference streamgage, its validity for ungaged locations at the distances common statewide is unknown. Other than in the pilot basin trials presented in this report, this assumption is untested in Pennsylvania.

Uncertainties in the constructed FDC for the ungaged locations consist of errors in the regression estimates of the 17 specified exceedance probabilities and uncertainties introduced through interpolation of the remaining unspecified exceedance probabilities of the FDC. Prediction errors for the regression estimates range from 11 to 92 percent (table 2). All other exceedance probabilities are interpolated. Archfield and others (2010) noted "hook" features when plotting observed and estimated daily mean streamflows at the highest and lowest streamflows and attributed that to an artifact of the log-linear interpolation between the exceedance probabilities that were used in Massachusetts. This hook feature 
was also prevalent in plots of observed and estimated streamflow for streamgages in Pennsylvania. A FDC for streamgage 01548500 using log-linear interpolation is shown in figure 9A; hook features are circled in red. Use of log-log interpolation smoothed out the hook features in the higher flows (fig. 9B). Other interpolations were examined to smooth the lower hook features, but without consistent results. The remaining hook features affect mainly the extreme low streamflows (well below P99) observed over the 49-year period, typically resulting in underprediction of extreme low flows.

To evaluate the effectiveness of the overall QPPQ method contained within BaSE, a comparison of observed and estimated daily mean streamflows was performed for all the streamgages in the pilot basins. Estimated streamflows were produced using the BaSE tool and the best correlated reference streamgage within the same pilot basin. Only periods with observed daily mean streamflows were compared. The comparison is intended to show how the BaSE tool can be expected to perform over the range of basin characteristics found across the State. Overall, the pilot basin streamgages are representative of the range of basin characteristics used in the development of the regression equations. With the exception of impervious land cover, more than 50 percent of the range of basin characteristics is represented by the pilot basin streamgages. NS efficiency values and percent rootmean-square-error (RMSE) were computed as a measure of goodness of fit. Median NS efficiencies ranged from 0.54 to 0.96 (median of 0.82) for the Lower Susquehanna River pilot basin and from 0.47 to 0.91 (median of 0.79 ) for the Upper Delaware River pilot basin (fig. 10A). RMSE ranged from 27 to 256 percent (median of 93 percent) for the Lower Susquehanna River pilot basin and from 43 to 228 percent (median of 65 percent) for the Upper Delaware River pilot basin (fig. 10B).

Hydrographs and FDCs generated in BaSE for streamgages 01556000, Frankstown Branch Juniata River at Williamsburg, Pa., and 01452500, Monocacy Creek at Bethlehem, Pa., are shown in figures $11 \mathrm{~A}$ and $11 \mathrm{~B}$, respectively. These streamgages represent the best (01556000) and worst (01452500) correlations for streamgages in the pilot basins with observed streamflow for WY 1960 to 2008. Streamgage 01556000 was associated with reference streamgage 01559000 with a correlation of 0.97 , and streamgage 01452500 was associated with reference streamgage 01451500 with a correlation of 0.90 for estimates of daily mean flow. The low-flow period from 1998 to 2002 is shown in the hydrographs in figure 11. Although both hydrographs show good general fit between the estimated and observed streamflow, the hydrograph for
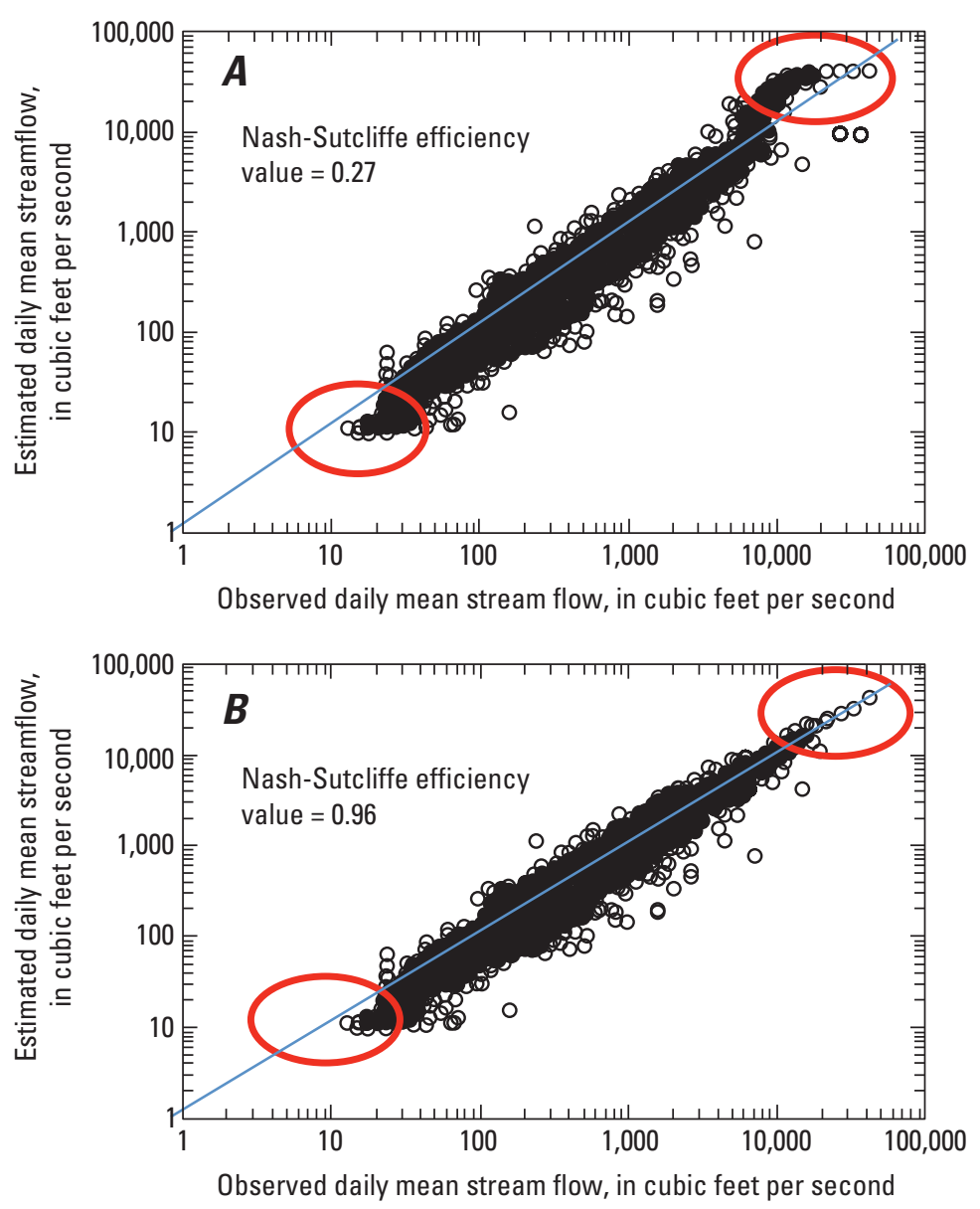

Figure 9. Observed and estimated daily mean streamflow for U.S. Geological Survey streamgage 01548500 Pine Creek at Cedar Run, Pa., using, $A$, log-linear interpolation and, $B$, log-log interpolation. 

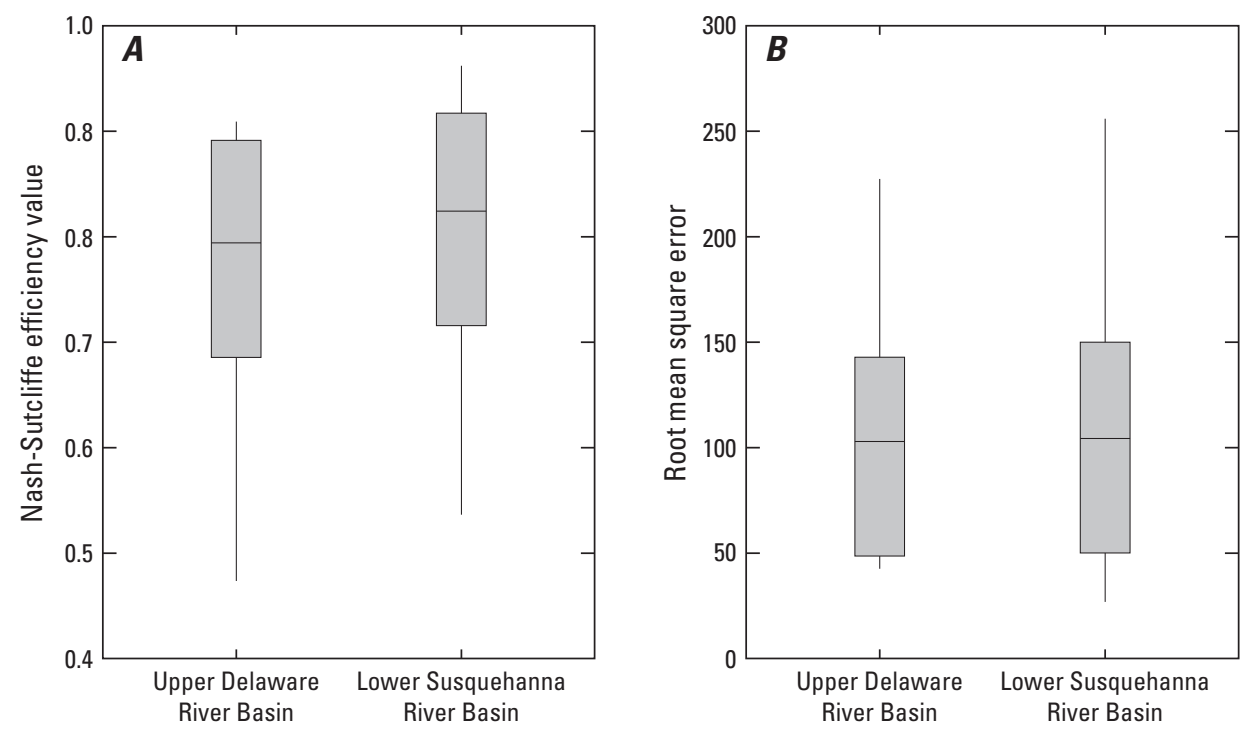

EXPLANATION

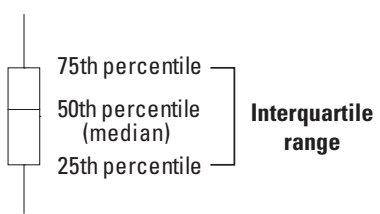

Figure 10. Distribution of, $A$, Nash-Sutcliffe efficiency values and, $B$, root mean square error obtained from comparison between observed and estimated daily mean streamflows in the two pilot basins in Pennsylvania.
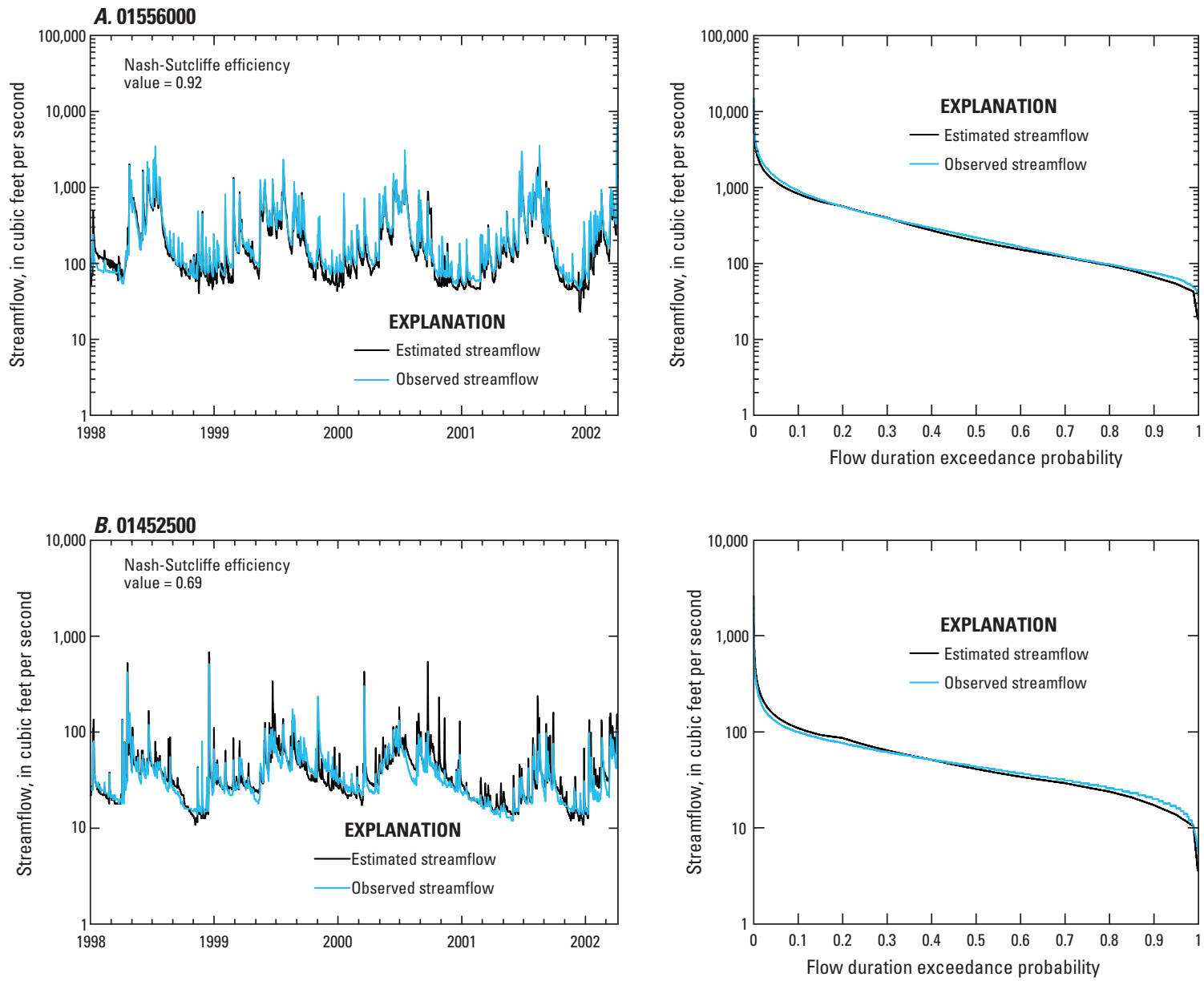

Figure 11. Hydrographs and flow duration curves showing estimated and observed daily mean flows for U.S. Geological Survey streamgages, $A, 01556000$, Frankstown Branch Juniata River at Williamsburg, Pa., and, $B$, 01452500, Monocacy Creek at Bethlehem, Pa. 
01452500 shows more variance, which is reflected in the lower NS value of 0.69 .

BaSE relies on estimates of streamflow derived from regression equations, and as such, it is not to be used for streams with basin characteristics outside the range used to develop the equations. Estimates of streamflow for streams with basin characteristics outside this range may not be valid. The range of basin characteristics used in the development of the regression equations is shown in table 6. Alterations to streamflow by regulation, mining, or other large water uses are not reflected in the estimated streamflows generated by BaSE, which are estimates of unaffected streamflows under baseline conditions. If groundwater and surface-water divides are not coincident, which can occur in areas with karst topography or mining, results from the regression equations and BaSE also may not be valid.

\section{Summary}

The ability to generate daily mean streamflow for any location on a stream in Pennsylvania is critical for waterresource managers. Water-allocation decisions, recreation resource decisions, and in-depth evaluation of flow regimes to promote instream ecological health often require streamflow information obtainable only from a time series hydrograph. Daily mean streamflow is not readily available for ungaged streams in Pennsylvania. The U.S. Geological Survey, in cooperation with the Pennsylvania Department of Environmental Protection, Susquehanna River Basin Commission, and The Nature Conservancy, has developed the Baseline Streamflow Estimator (BaSE) to estimate minimally altered or "baseline" daily mean streamflow for ungaged streams in Pennsylvania for water years 1960 to 2008. BaSE uses a modified QPPQ approach that equates the streamflow as a percentile from the flow duration curve (FDC) for a particular day at an ungaged location with the streamflow as a percentile for the same day at a reference streamgage. Correlation of streamflow is used to select an appropriate reference streamgage for the ungaged location. Streamflows corresponding to the percentile for the ungaged location are selected from a daily FDC constructed from points determined by regression equations using basin characteristics.

Flow-duration exceedance probability regression equations were developed for 17 percentiles along the FDC using data from 162 streamgages from the 1960 water year through the 2008 water year. The standard errors of prediction for the flow-duration regression equations range from 11 percent to 92 percent, with the average standard error over the entire suite of equations equal to 31 percent.

The map correlation method was tested in two pilot basins - the Lower Susquehanna River Basin and the Upper Delaware River Basin - to confirm applicability for use in Pennsylvania. The map correlation method performed as well as, or better than, the closest centroid method for selecting reference sites in the basins and offers consistency and reliability in the approach. Therefore, variogram models were developed for a subset of the reference streamgage dataset with minimally altered streamflow in and near Pennsylvania using a spherical distribution model.

The BaSE tool estimates the daily mean streamflow for an ungaged location by first selecting a reference streamgage using the map correlation method as a default. An option is available for a manual choice by the user. After selecting a reference streamgage, BaSE then equates the percentiles at the gaged site for a particular day with percentiles at the ungaged location for the same day. The percentiles are converted to streamflow at the ungaged location using regression equations and interpolation. BaSE outputs a report file in Microsoft Excel ${ }^{\circledR}$ summarizing the reference streamgage and ungaged location information, including basin characteristics, percent difference in basin characteristics between the two sites, any warning associated with the basin characteristics, mean and

Table 6. Basin characteristics with minimum, maximum, and mean values used in development of regression equations to estimate flow-duration exceedance probabilities with BaSE for basins in Pennsylvania.

\begin{tabular}{lccc}
\hline \multicolumn{1}{c}{ Basin characteristic } & Minimum & Maximum & Mean \\
\hline Longitude (decimal degrees) & 74.9856 & 80.9953 & 77.6276 \\
Drainage area (square mile) & 2.39 & 1,462 & 171 \\
Percent impervious area & 0.02 & 29.2 & 2.5 \\
Percent carbonate bedrock & 0 & 83.2 & 6.9 \\
Mean annual precipitation (inches) & 32.4 & 48.9 & 42 \\
Mean maximum daily temperature (degrees Fahrenheit) & 52.3 & 62.0 & 57.3 \\
Soil depth to bedrock (feet) & 3.18 & 6.12 & 4.64 \\
Drainage runoff number & & 5.44 & 3.57 \\
\hline
\end{tabular}

${ }^{1}$ Unit less $1=$ well to $7=$ poor 
median streamflows, and hydrographs for the ungaged location. The daily mean streamflow for the ungaged location can be exported as a text file to be used as input into separate statistical software for further analysis.

Accuracy of estimated baseline daily mean streamflow for ungaged locations is affected by the uncertainties introduced by the multiple steps involved in the process. Uncertainty is introduced during the selection of the reference streamgage, estimation of exceedance probabilities for the ungaged location, and the QPPQ process. It is difficult to quantify the overall uncertainty associated with the estimated daily mean flows at the ungaged location because of the number of potential sources. Observed and estimated daily mean flows for reference streamgages in the two pilot basins were examined for accuracy. Median Nash-Sutcliffe efficiency values ranged from 0.47 to 0.96 , and root mean square errors ranged from 27 to 256 percent for the streamgages in the pilot basins. BaSE is not to be used to estimate daily mean streamflow in basins with basin characteristics outside the range used to develop the equations. Alterations to streamflow by regulation, mining, or other large water uses are not reflected in the estimated streamflow values generated by BaSE. If the groundwater and surface-water divides are not coincident, which can occur in areas with karst topography or mining, results from the regression equations and BaSE may not be valid.

\section{References Cited}

Apse, C., Dephilip, M., Zimmerman, J., and Smith, M.P., 2008, Developing instream flow criteria to support ecologically sustainable water resource planning and management: Harrisburg, Pa: The Nature Conservancy, p. 195

Archfield, S.A., Vogel, R.M., Steeves, P.A., Brandt, S.L., Weiskel, P.K., and Garabedian, S.P., 2010, The Massachusetts Sustainable-Yield Estimator: A decision-support tool to assess water availability at ungaged stream locations in Massachusetts: U.S. Geological Survey Scientific Investigations Report 2009-5227, 41 p., plus CD-ROM.

Archfield, S. A., and R. M. Vogel, 2010, Map correlation method: Selection of a reference streamgage to estimate daily streamflow at ungaged catchments: Water Resources Research, no. 46, W10513, doi:10.1029/2009WR008481.

Daly, Christopher, 1996, Overview of the PRISM Model, accessed December 7, 2011, at http://www.ocs.orst.edu/ prism/overview.html.

DePhilip, M., and Moberg, T., 2010, Ecosystem Flow Recommendations for the Susquehanna River Basin: The Nature Conservancy, $96 \mathrm{p}$.
Environmental Resources Research Institute, 1996, Areas of carbonate lithology: Pennsylvania Department of Environmental Protection, accessed December 7, 2011, at http:// www.pasda.psu.edu/.

Environmental Systems Research Institute, Inc., 2009, accessed August 4, 2009, at http://www.esri.com/.

Fennessey, N.M., 1994, A hydro-climatological model of daily streamflow for the northeast United States: Medford, Mass., Tufts University, Ph.D. dissertation [variously paged].

Granato, G.E., 2009, Computer programs for obtaining and analyzing daily mean streamflow data from the U.S. Geological Survey National Water Information System Web Site: U.S. Geological Survey Open-File Report 2008-1362, 123 p. on CD-ROM, 5 append.

Helsel, D.R., and Hirsch, R.M., 1992, Studies in environmental science 49-Statistical methods in water resources: Amsterdam, Elsevier, 522 p.

Henriksen, J.A, Heasley, J., Kennen, J.G., and Nieswand, S., 2006, Users' manual for the Hydroecological Integrity Assessment Process software (including the New Jersey Assessment Tools): U.S. Geological Survey Open-File Report 2006-1093, 72 p.

Hirsch, R.M., 1982, A comparison of four streamflow record extension techniques: Water Resources Research, v. 18, no. 4, p. 1081-1088.

Homer, C., Huang, C., Yang, L., Wylie, B., and Coan, M., 2004, Development of a 2001 National Landcover Database for the United States: Photogrammetric Engineering and Remote Sensing, v. 70, no. 7, July 2004, p. 829-840, accessed December 7, 2011, at http://www.mrlc.gov/ mrlc $2 k$ publications.asp.

Huang, W-C., and Yang, F-T., 1998, Streamflow estimation using kriging: Water Resources Research, v. 34, no. 6, p. 1599-1608.

Hughes, D.A., and Smakhtin, V.U., 1996, Daily flow time series patching or extension: a spatial interpolation approach based on flow duration curves: Journal of Hydrological Sciences, v. 41, no. 6, p. 851-871.

Isaaks, E.H., and Srivastava, R.M., 1989, An Introduction to Applied Geostatistics: New York and Oxford, Oxford University Press, $561 \mathrm{p}$.

Mohamoud, Y. M., 2008, Prediction of daily flow duration curves and streamflow for ungauged catchments using regional flow duration curves: Journal of Hydrological Sciences, v. 53, no. 4, p. 706-724. 
Pennsylvania Department of Conservation and Natural Resources, 1997, Glacial deposits of Pennsylvania: Bureau of Topographic and Geologic Survey, accessed December 7, 2011, at http://www.dcnr.state.pa.us/topogeo/field/glacial. aspx.

Poff, N.L., Richter, B., Arthington, A.H., Bunn, S.E., Naiman, R.J., Kendy, E., Acreman, M., Apse, C., Bledsoe, B.P., Freeman, M., Henriksen, J., Jacobson, R.B., Kennen, J., Merritt, D.M., O’Keeffe, J., Olden, J.D., Rogers, K., Tharme, R.E., and Warner, A., 2010, The Ecological Limits of Hydrologic Alteration (ELOHA): a new framework for developing regional environmental flow standards: Freshwater Biology, no. 55 , p. $147-170$.

Price, C., Nakagaki, N., Hitt, K., and Clawges, R., 2003, Mining GIRAS: Improving on a national treasure of land use data: ESRI International User Conference 2003 Proceedings, accessed December 7, 2011, at http://gis.esri.com/ library/userconf/proc03/p0904.pdf.

Risser, D.W., Thompson, R.E., and Stuckey, M.H., 2008, Regression method for estimating long-term mean annual ground-water recharge rates from base flow in Pennsylvania: U.S. Geological Survey Scientific Investigations Report 2008-5185, 23 p.

Roland, M.A., and Stuckey, M.H., 2008, Regression equations for estimating magnitude and frequency of peak flows for ungaged streams in Pennsylvania: U.S. Geological Survey Scientific Investigations Report 2008-5102, 76 p.

Searcy, J. K., 1959, Flow-duration curves: U.S. Geological Survey Water-Supply Paper 1542-A, p. 1-33.

Searcy, J.K., 1960, Graphical correlation of gaging-station records: U.S. Geological Survey Water-Supply Paper 1541-C, p. 67-100.

Shu, C., and Ourda, T.B.M.J., 2012, Improved methods for daily streamflow estimates at ungaused sites: Water Resources Research, v. 48, W02523, doi:10.1029/2011WR011501.

Skøien, J.O., and Blöschl, G., 2007, Spatiotemporal topological kriging of runoff time series: Water Resources Research, 43, W09419, doi:10.1029/2006WR005760.

Smakhtin, V.U., 1999, Generation of natural daily flow time series in regulated rivers using nonlinear spatial interpolation technique: Regulated Rivers Research and Management v. $15,12 \mathrm{p}$.

Smakhtin, V.U., and Masse, B., 2000, Continuous daily hydrograph simulation using duration curves of a precipitation index: Hydrological Processes, v. 14, p. 1,083-1,100.
Stuckey, M.H., 2006, Low-flow, base-flow, and mean-flow regression equations for Pennsylvania streams: U.S. Geological Survey Scientific Investigations Report 2006-5130, $84 \mathrm{p}$.

Stuckey, M.H., 2008, Development of the Water-Analysis Screening Tool used in the initial screening for the Pennsylvania State Water Plan update of 2008: U.S. Geological Survey Open-File Report 2008-1106, 9 p.

Stuckey, M.H., and Hoffman, S.A., 2010, Pennsylvania StreamStats: A web-based application for obtaining waterresource-related information: U.S. Geological Survey Fact Sheet 2010-3086, 2 p.

Stuckey, M.H., and Roland, M.A., 2011, Selected streamflow statistics for streamgage locations in and near Pennsylvania: U.S. Geological Survey Scientific Investigations Report 2011-1070, 88 p.

The Nature Conservancy, 2009, Indicators of Hydrologic Alteration Version 7.1 User's Manual: The Nature Conservancy, April 2009, 76 p.

TIBCO Software Inc., 2008, TIBCO Spotfire S+ 8.1 Guide to Packages: Palo Alto, Calif., 77 p.

U.S. Department of Agriculture, 1994, State Soil Geographic (STATSGO) Data Base: Washington D.C.: Miscellaneous Publication Number 1492, 33 p., accessed June 19, 2012, at http://dbwww.essc.psu.edu/dbtop/doc/statsgo/statsgo_info. html.

U.S. Geological Survey, 2000a, U.S. GeoData Digital Elevation Models: U.S. Geological Survey Fact Sheet 040-00, 3 p., accessed December 7, 2011, at http://erg.usgs.gov/isb/ pubs/factsheets/fs04000.html.

U.S. Geological Survey, 2000b, NHD User Guide, accessed December 7, 2011, at http://nhd.usgs.gov/userguide.html.

Vogel, R.M., and Fennessey, N.M., 1994, Flow-duration curves I: A new interpretation and confidence intervals: ASCE Journal of Water Resources Planning and Management, v. 120, no. 4, p. 485-504.

Vogel, R.M., and Stedinger, J.R., 1985, Minimum variance streamflow record augmentation procedures: Water Resources Research, v. 21, no. 5, p. 715-723.

Waldron, M.C., and Archfield, S.A., 2006, Factors affecting firm yield and the estimation of firm yield for streamflowdominated drinking-water-supply reservoirs in Massachusetts: U.S. Geological Survey Scientific Investigations Report 2006-5044, 39 p. 
Appendixes 1-4 


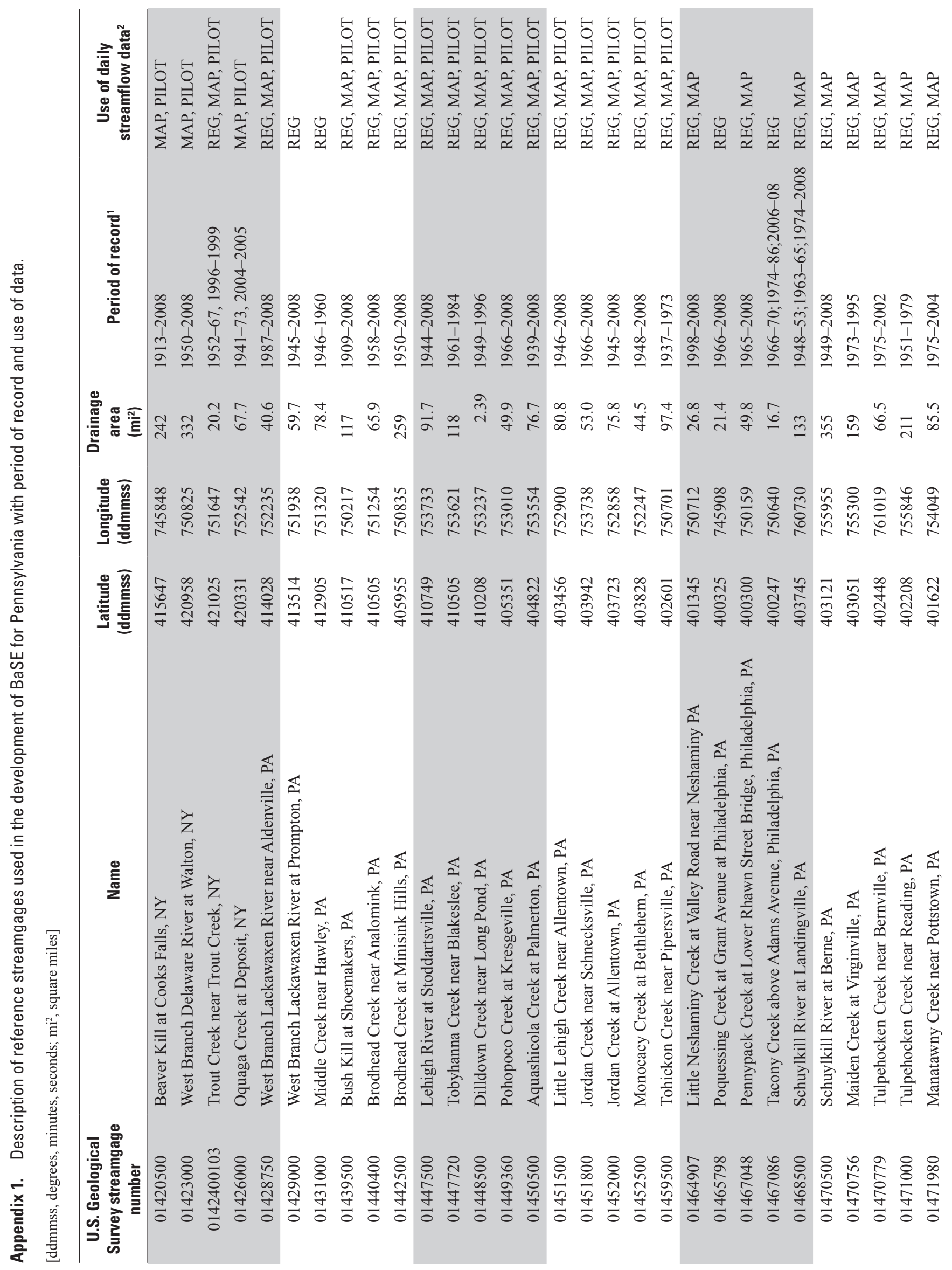




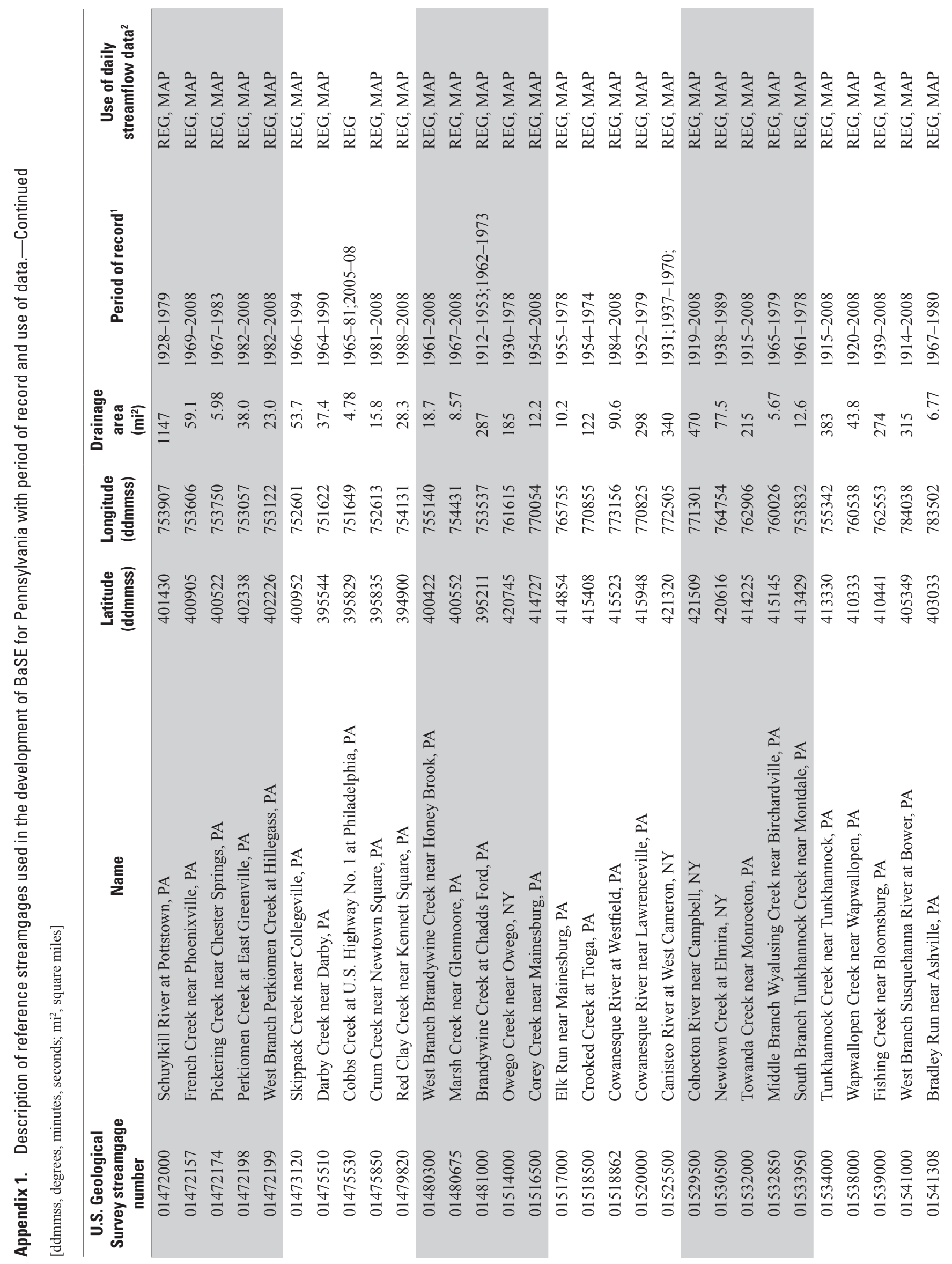




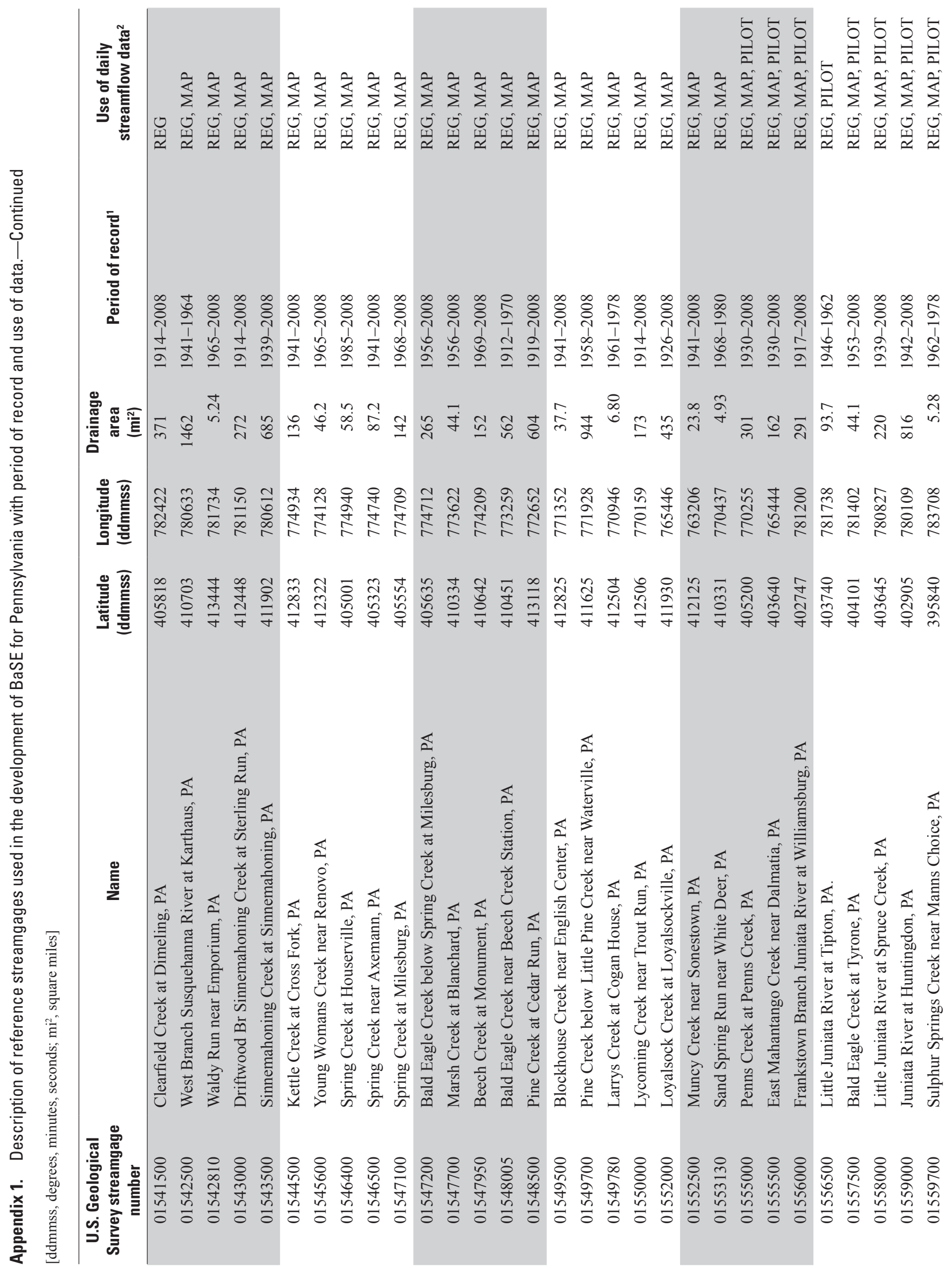




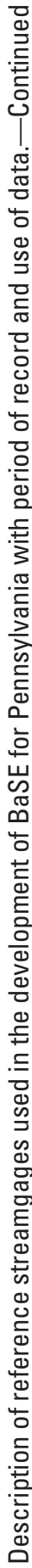

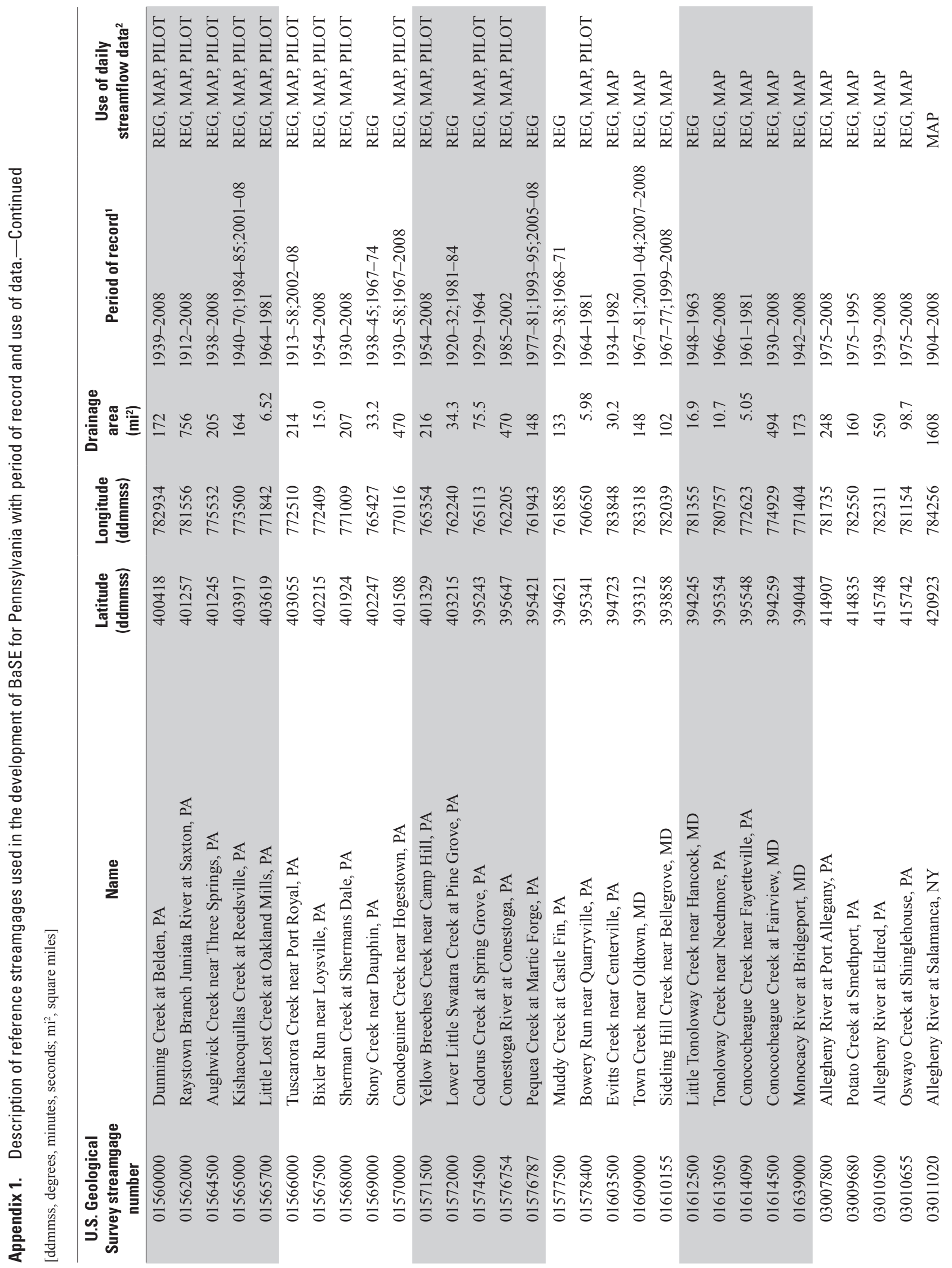




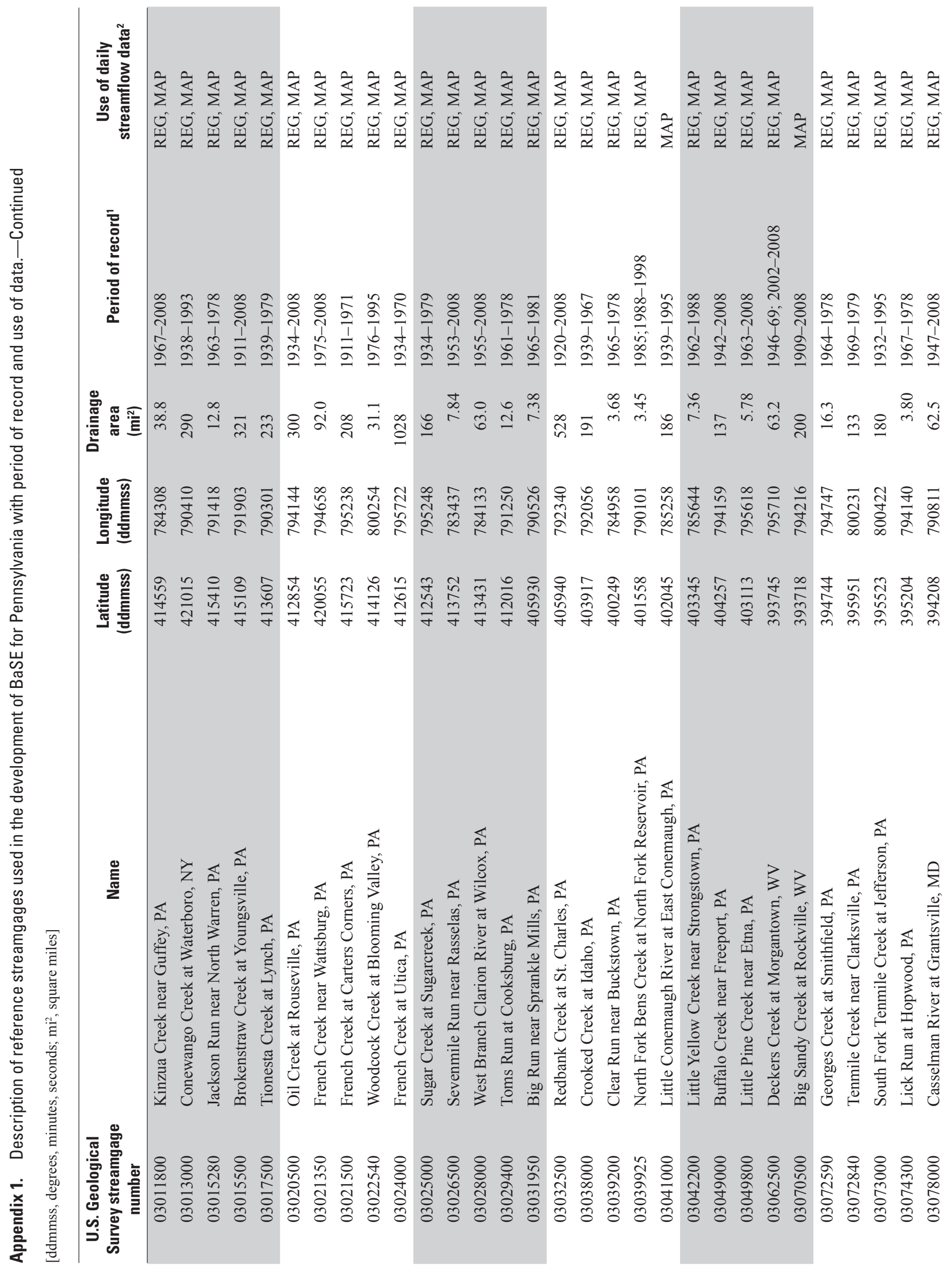




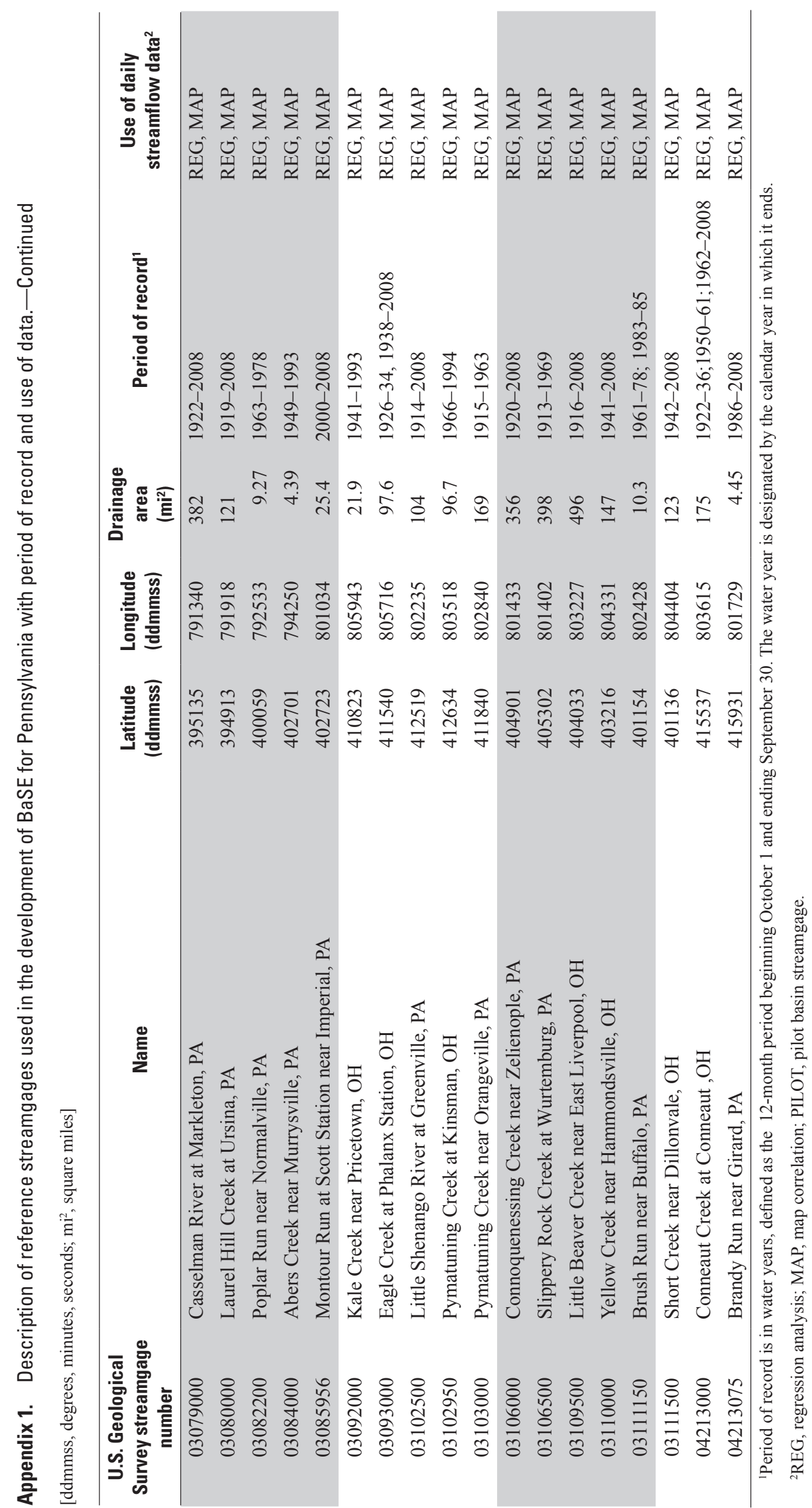




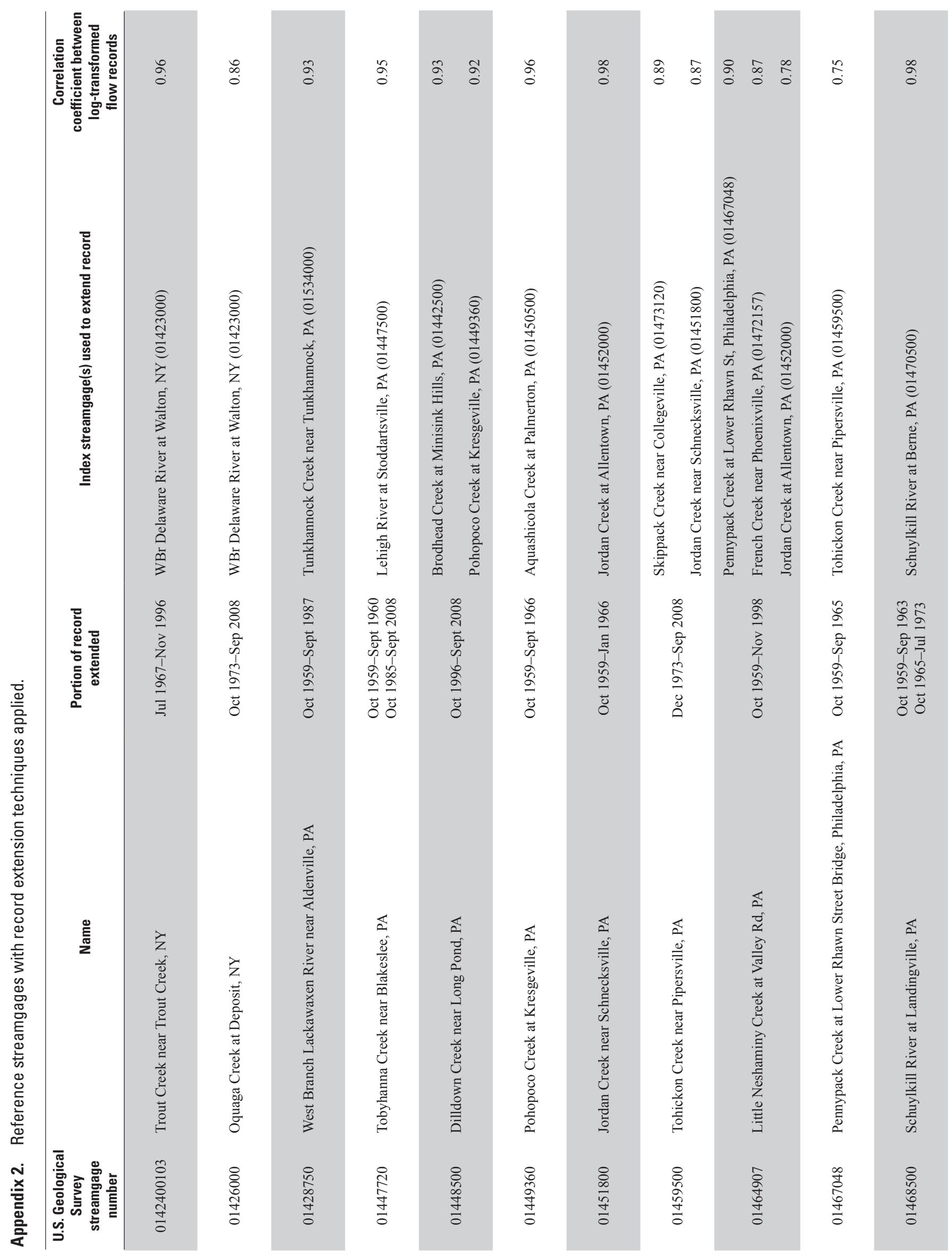




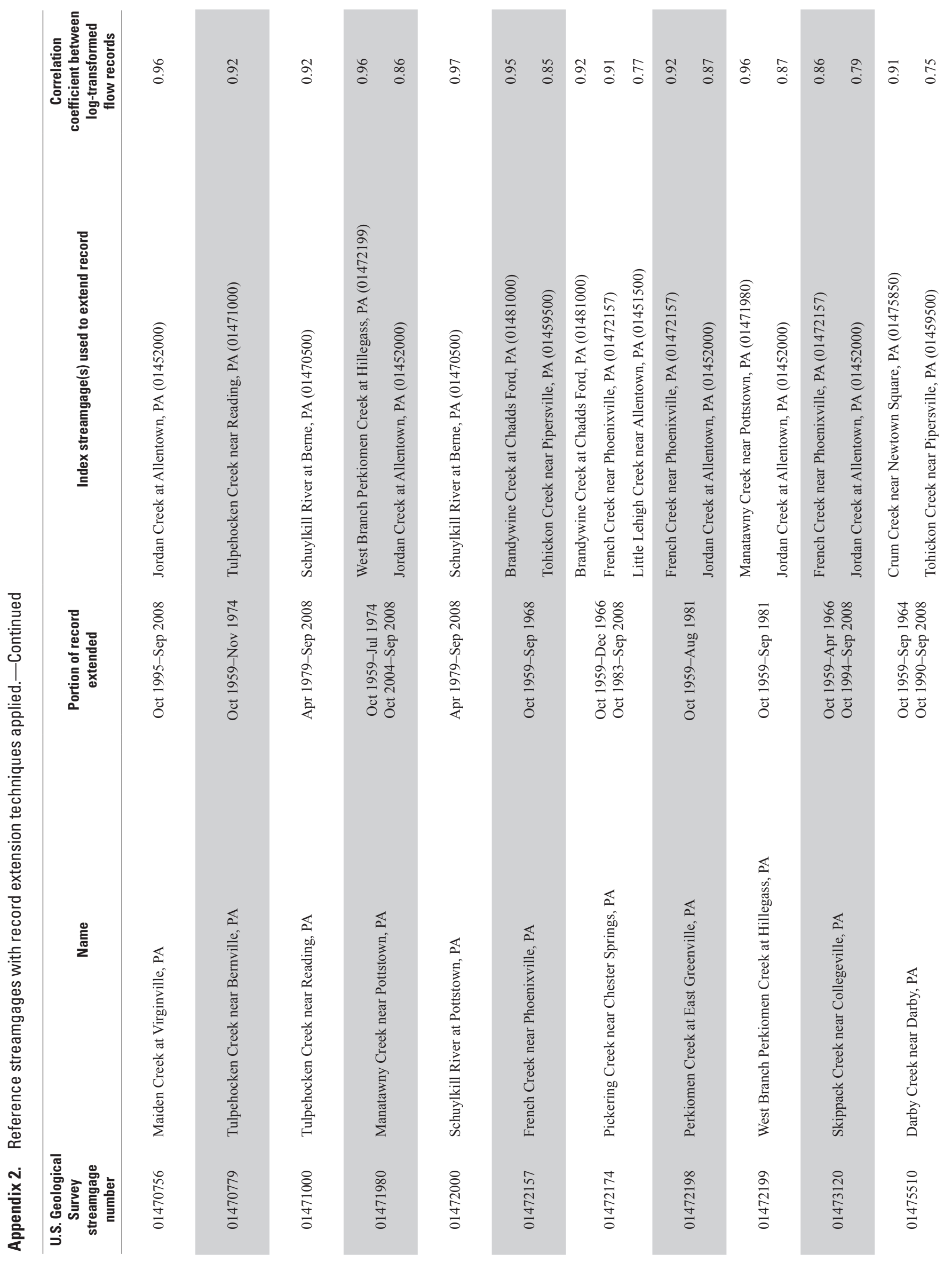




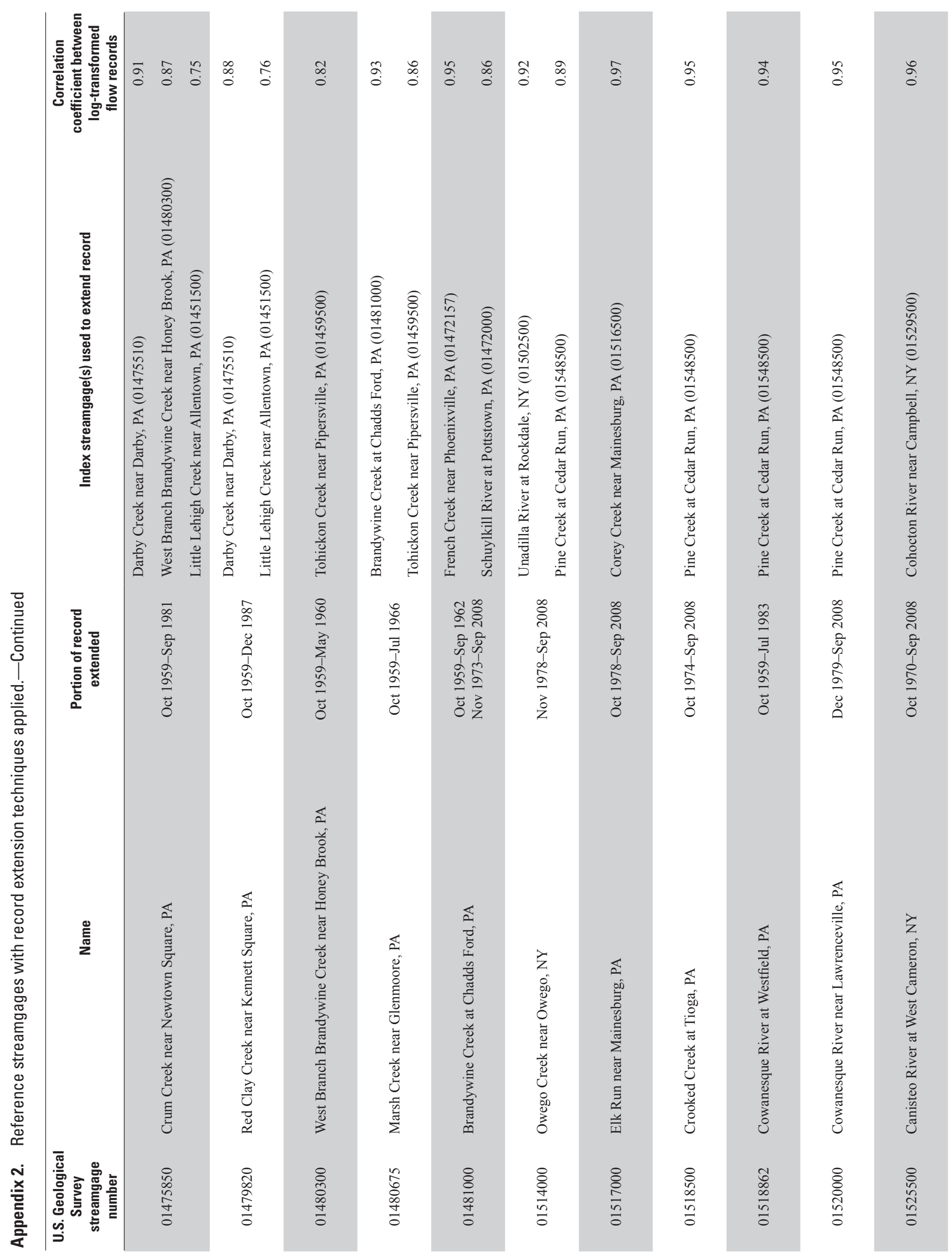









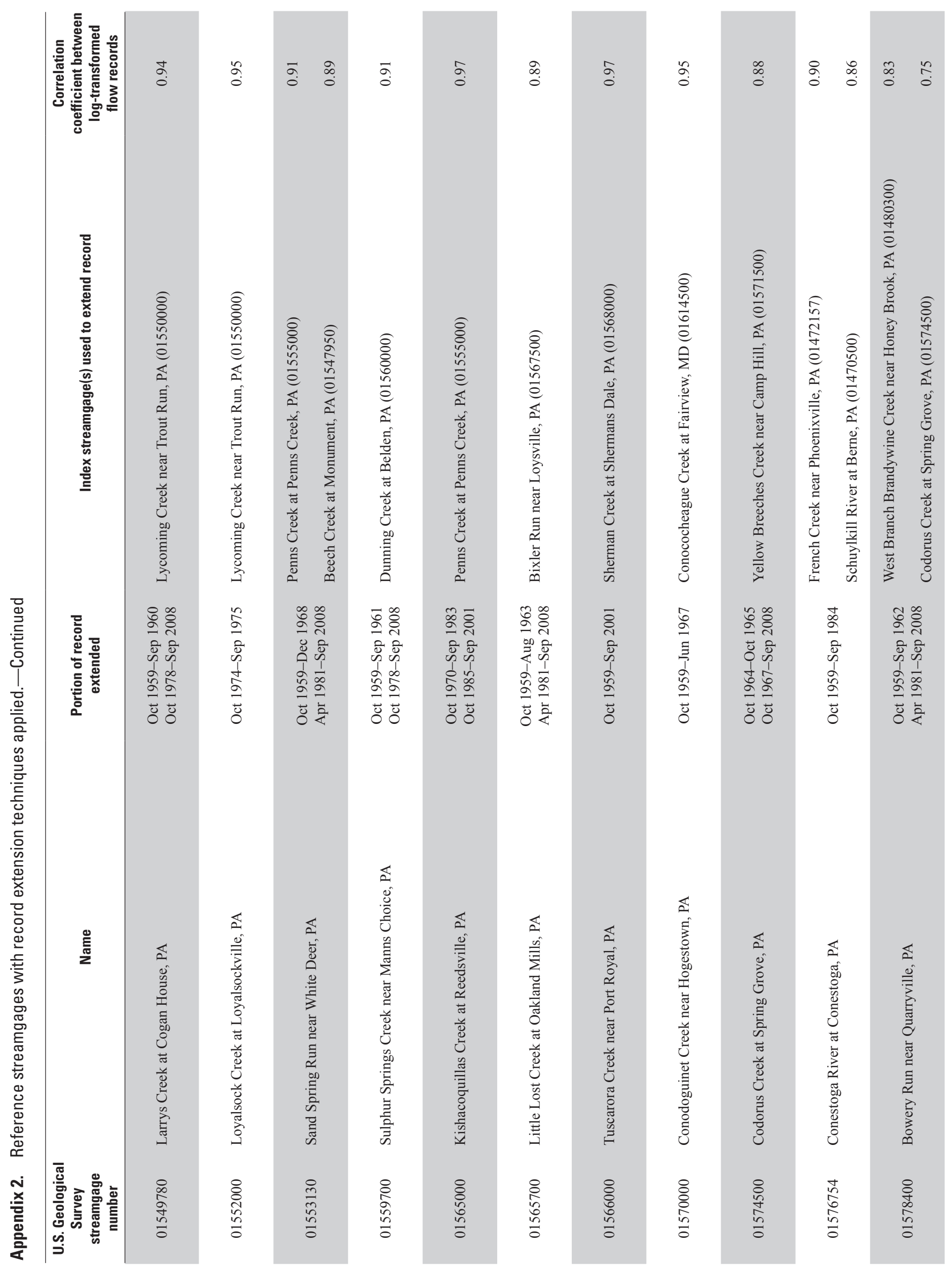




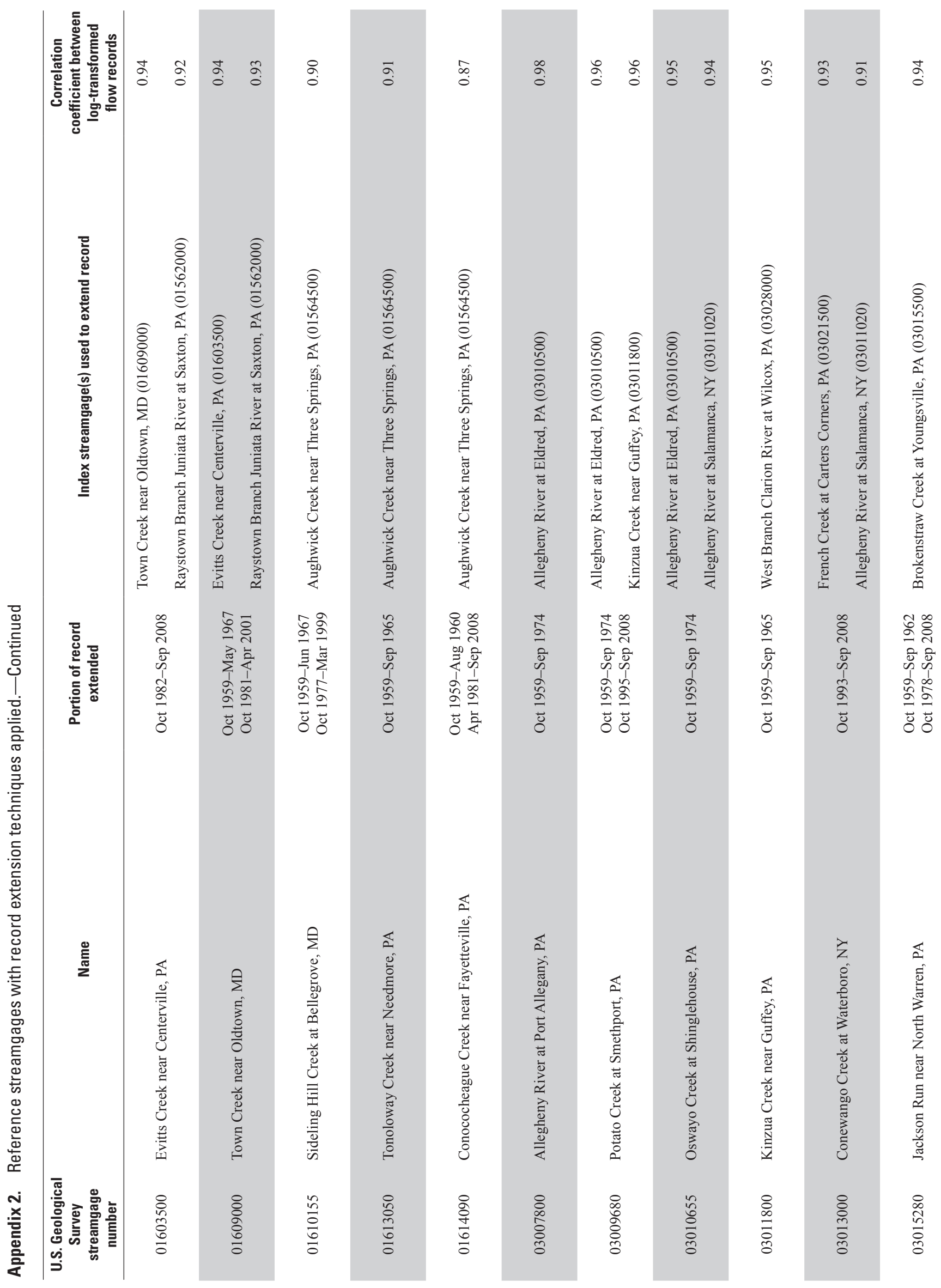




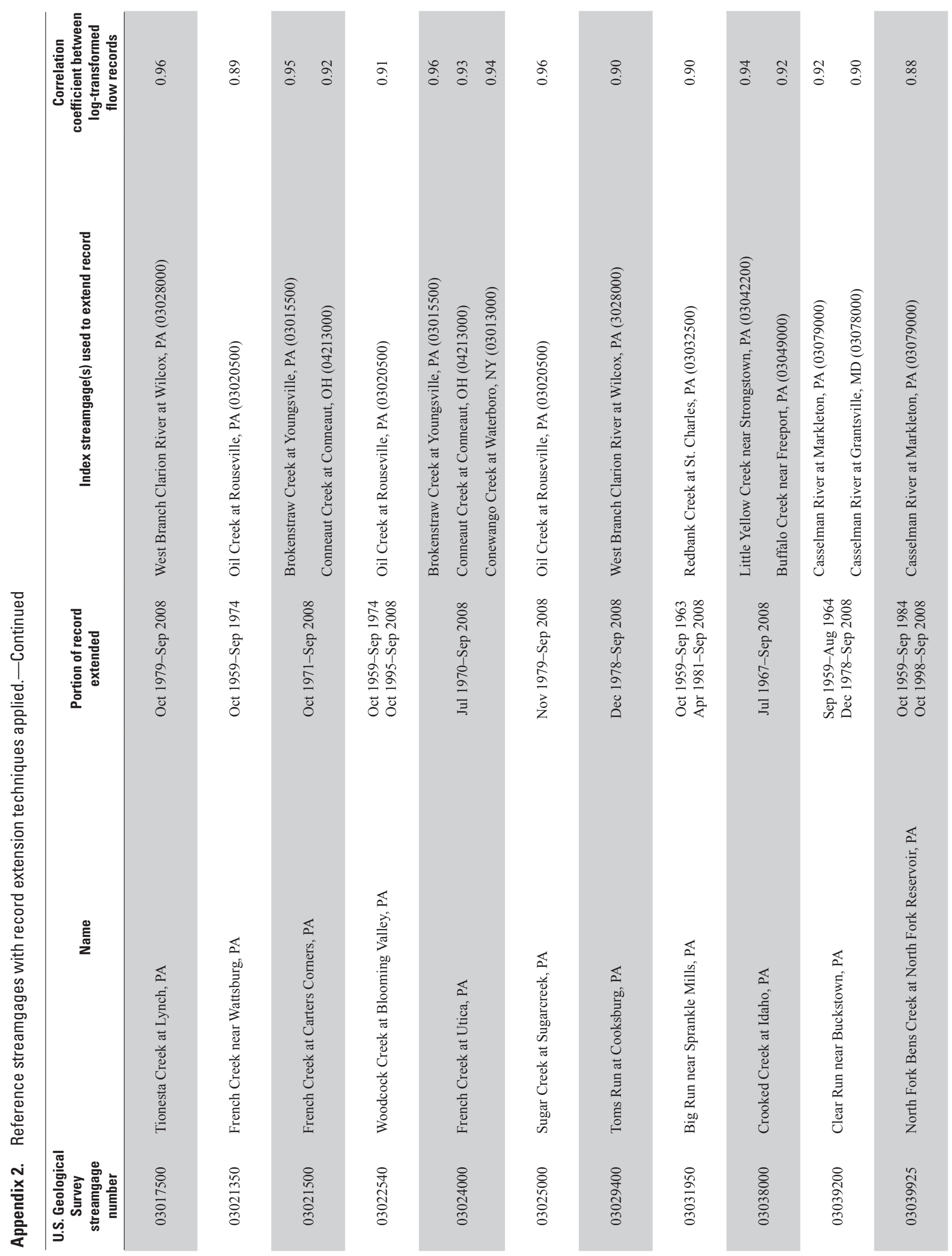




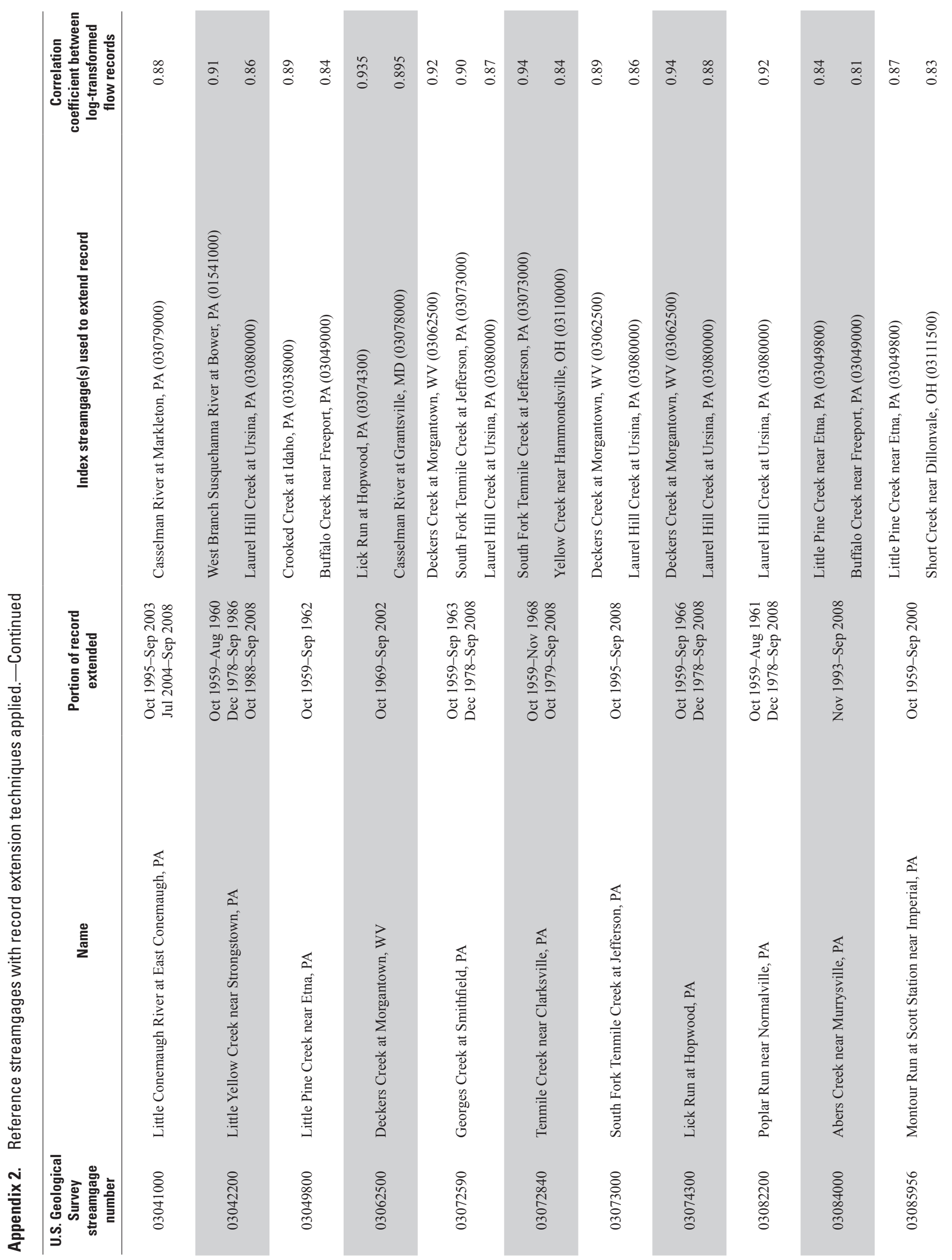




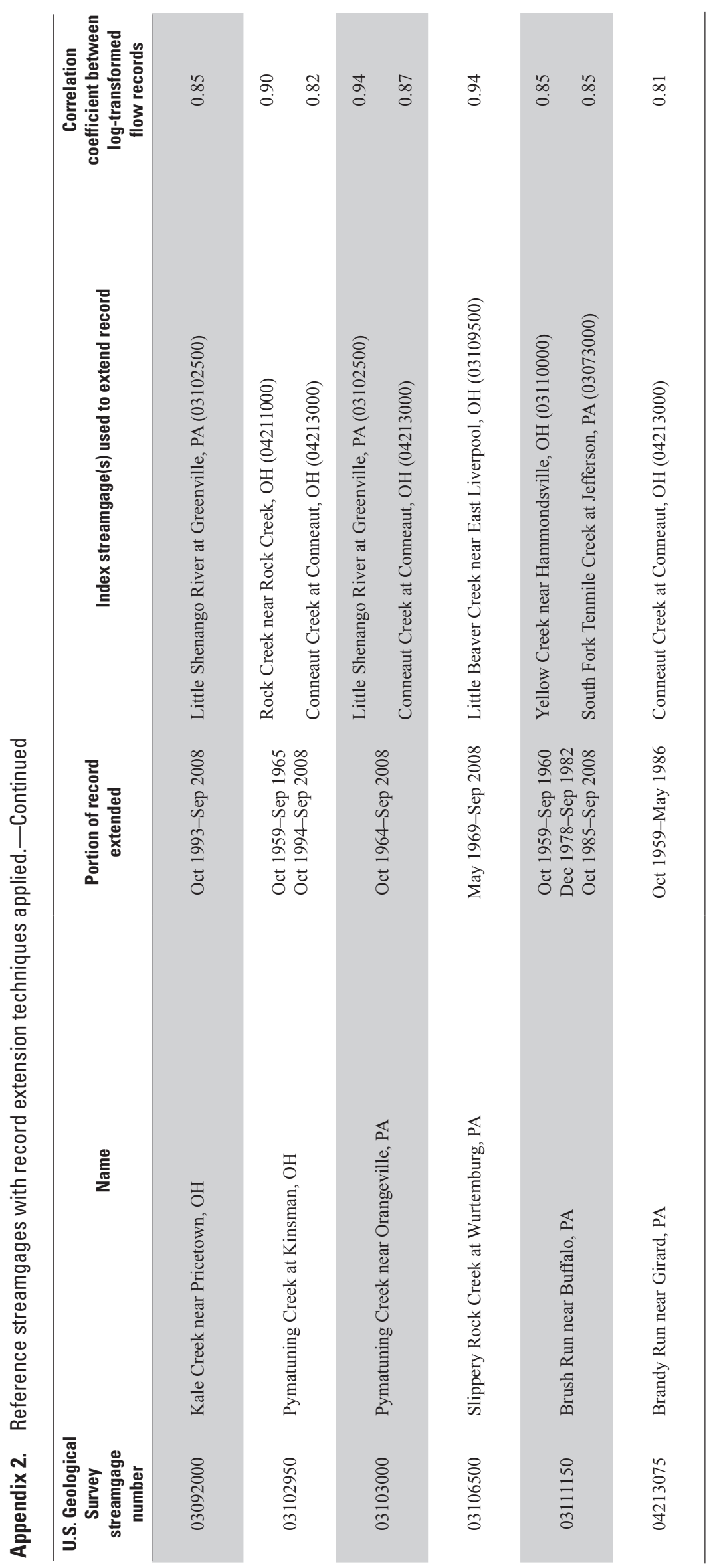


Appendix 3. Basin characteristics used in the development of flow-duration regression equations.

\begin{tabular}{|c|c|c|c|c|c|c|c|c|}
\hline $\begin{array}{c}\text { U.S. Geological } \\
\text { Survey } \\
\text { streamgage } \\
\text { number }\end{array}$ & $\begin{array}{l}\text { Longitude } \\
\text { (decimal } \\
\text { degrees) }\end{array}$ & $\begin{array}{l}\text { Drainage } \\
\text { area } \\
\text { (square } \\
\text { miles) } \\
\end{array}$ & $\begin{array}{l}\text { Percent } \\
\text { impervious } \\
\text { area }\end{array}$ & $\begin{array}{c}\text { Percent } \\
\text { carbonate } \\
\text { bedrock }\end{array}$ & $\begin{array}{c}\text { Mean annual } \\
\text { precipitation } \\
\text { (inches) }\end{array}$ & $\begin{array}{c}\text { Mean maximum } \\
\text { daily temperature } \\
\text { (degrees } \\
\text { Fahrenheit) } \\
\end{array}$ & $\begin{array}{l}\text { Soil depth } \\
\text { to bedrock } \\
\text { (feet) }\end{array}$ & $\begin{array}{c}\text { Drainage } \\
\text { runoff } \\
\text { number } \\
\text { (unitless) }\end{array}$ \\
\hline 0142400103 & 75.280 & 20.2 & 0.38 & 0 & 43.2 & 53.2 & 4.76 & 3.63 \\
\hline 01428750 & 75.376 & 40.6 & 0.28 & 0 & 45.4 & 52.3 & 4.46 & 4.06 \\
\hline 01429000 & 75.327 & 59.7 & 0.29 & 0 & 44.8 & 52.8 & 4.57 & 4.04 \\
\hline 01431000 & 75.222 & 78.4 & 0.48 & 0 & 42.9 & 54.7 & 4.65 & 3.96 \\
\hline 01439500 & 75.038 & 117 & 0.35 & 0 & 43.4 & 55.1 & 5.05 & 3.95 \\
\hline 01440400 & 75.215 & 65.9 & 0.39 & 0 & 44.5 & 54.3 & 4.66 & 3.97 \\
\hline 01442500 & 75.143 & 259 & 2.71 & 0.06 & 46.3 & 56.2 & 4.81 & 3.93 \\
\hline 01447500 & 75.626 & 91.7 & 0.59 & 0 & 46.0 & 53.1 & 4.88 & 3.97 \\
\hline 01447720 & 75.606 & 118 & 1.67 & 0 & 47.6 & 52.9 & 5.07 & 4.10 \\
\hline 01448500 & 75.544 & 2.39 & 0.27 & 0 & 48.9 & 53.1 & 4.75 & 3.80 \\
\hline 01449360 & 75.503 & 49.9 & 2.49 & 0 & 47.4 & 57.2 & 4.55 & 3.26 \\
\hline 01450500 & 75.598 & 76.7 & 1.70 & 4.91 & 45.8 & 58.5 & 4.51 & 3.24 \\
\hline 01451500 & 75.483 & 80.8 & 8.24 & 63.7 & 45.2 & 59.9 & 5.11 & 3.22 \\
\hline 01451800 & 75.627 & 53.0 & 1.62 & 0 & 45.6 & 59.8 & 3.38 & 3.10 \\
\hline 01452000 & 75.483 & 75.8 & 3.56 & 11.3 & 45.4 & 59.9 & 3.65 & 3.11 \\
\hline 01452500 & 75.380 & 44.5 & 8.55 & 62.8 & 44.6 & 59.7 & 4.50 & 3.19 \\
\hline 01459500 & 75.117 & 97.4 & 2.91 & 0 & 45.0 & 60.3 & 4.43 & 4.32 \\
\hline 01464907 & 75.120 & 26.8 & 13.8 & 0 & 45.0 & 61.7 & 4.20 & 4.48 \\
\hline 01465798 & 74.986 & 21.4 & 29.2 & 1.03 & 47.0 & 62.0 & 4.18 & 4.15 \\
\hline 01467048 & 75.033 & 49.8 & 22.7 & 1.43 & 45.6 & 61.9 & 4.79 & 3.64 \\
\hline 01467086 & 75.111 & 16.2 & 24.5 & 0 & 45.0 & 62.0 & 5.12 & 3.29 \\
\hline 01468500 & 76.125 & 133 & 4.16 & 0 & 48.7 & 57.2 & 4.45 & 3.15 \\
\hline 01470500 & 75.999 & 355 & 2.83 & 0.12 & 48.7 & 57.7 & 4.47 & 3.13 \\
\hline 01470756 & 75.883 & 159 & 1.51 & 10.8 & 46.8 & 59.8 & 3.84 & 3.13 \\
\hline 01470779 & 76.172 & 66.5 & 4.12 & 83.2 & 43.3 & 60.0 & 5.16 & 3.23 \\
\hline 01471000 & 75.979 & 211 & 3.29 & 41.3 & 44.7 & 59.8 & 4.40 & 3.20 \\
\hline 01471980 & 75.680 & 85.5 & 0.94 & 26.1 & 46.0 & 60.3 & 5.13 & 3.33 \\
\hline 01472000 & 75.652 & 1,147 & 3.85 & 18.7 & 46.5 & 58.6 & 4.43 & 3.22 \\
\hline 01472157 & 75.602 & 59.1 & 0.47 & 0.62 & 44.9 & 60.2 & 4.90 & 3.39 \\
\hline 01472174 & 75.631 & 5.98 & 3.65 & 0 & 45.0 & 60.3 & 5.09 & 3.30 \\
\hline 01472198 & 75.516 & 38.0 & 1.72 & 3.35 & 45.3 & 60.3 & 4.83 & 3.44 \\
\hline 01472199 & 75.523 & 23.0 & 1.01 & 4.76 & 46.2 & 60.3 & 4.85 & 3.47 \\
\hline 01473120 & 75.434 & 53.7 & 9.60 & 0 & 43.1 & 61.8 & 4.13 & 3.93 \\
\hline 01475510 & 75.273 & 37.4 & 15.7 & 0 & 44.7 & 61.6 & 4.85 & 3.57 \\
\hline 01475530 & 75.280 & 4.78 & 22.8 & 0 & 45.0 & 61.9 & 5.03 & 3.36 \\
\hline 01475850 & 75.437 & 15.8 & 3.62 & 0 & 45.0 & 60.7 & 4.93 & 3.71 \\
\hline 01479820 & 75.692 & 28.3 & 3.73 & 11.1 & 45.0 & 60.8 & 5.13 & 3.29 \\
\hline 01480300 & 75.861 & 18.7 & 1.37 & 3.36 & 45.0 & 59.8 & 5.08 & 3.28 \\
\hline 01480675 & 75.742 & 8.57 & 0.64 & 0.39 & 45.0 & 60.0 & 5.09 & 3.30 \\
\hline 01481000 & 75.594 & 287 & 3.40 & 7.63 & 45.0 & 60.5 & 5.11 & 3.36 \\
\hline 01514000 & 76.271 & 185 & 0.35 & 0 & 37.0 & 53.8 & 4.44 & 3.78 \\
\hline 01516500 & 77.015 & 12.2 & 0.39 & 0 & 34.8 & 54.2 & 4.64 & 4.05 \\
\hline
\end{tabular}


Appendix 3. Basin characteristics used in the development of flow-duration regression equations.-Continued

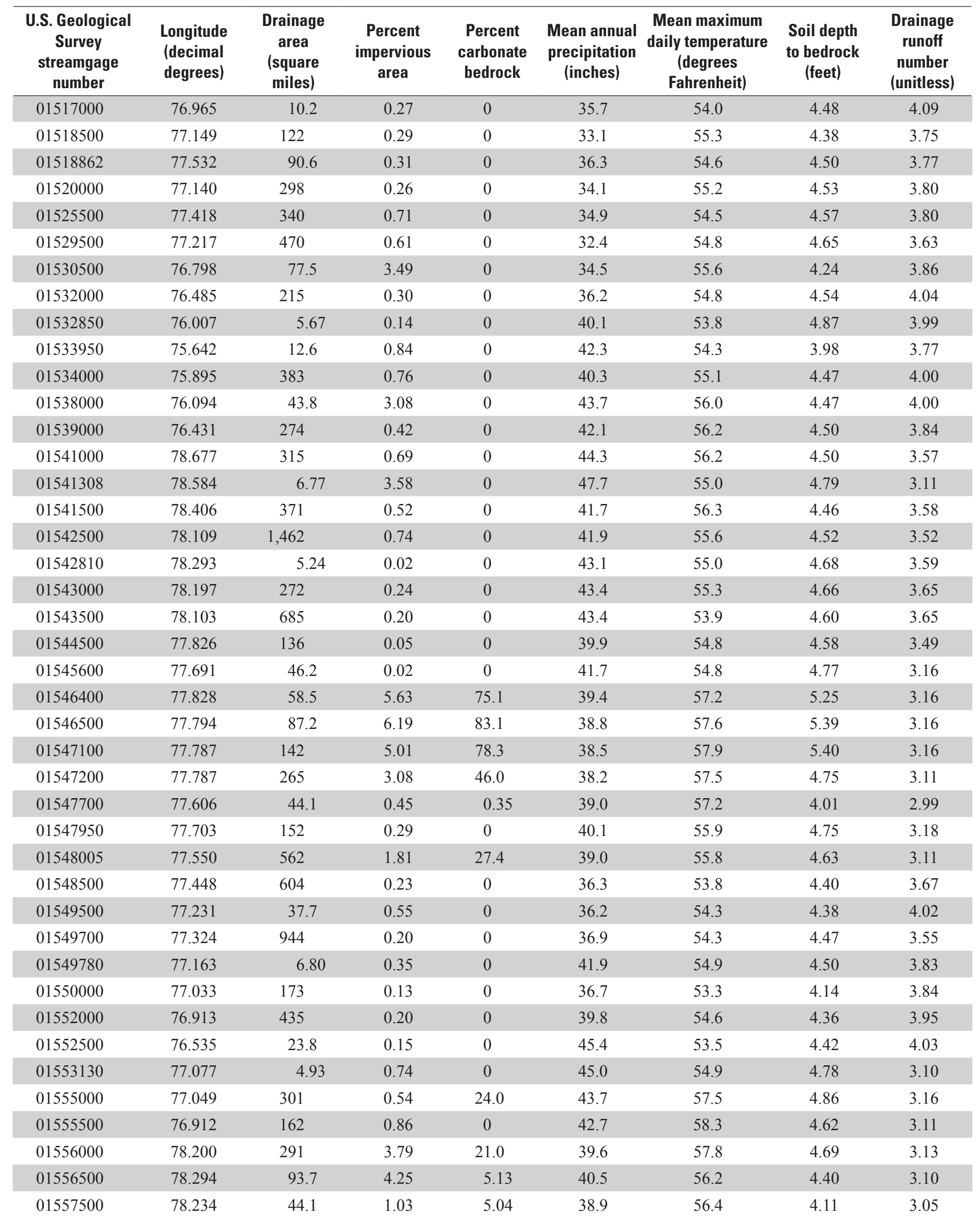


Appendix 3. Basin characteristics used in the development of flow-duration regression equations.-Continued

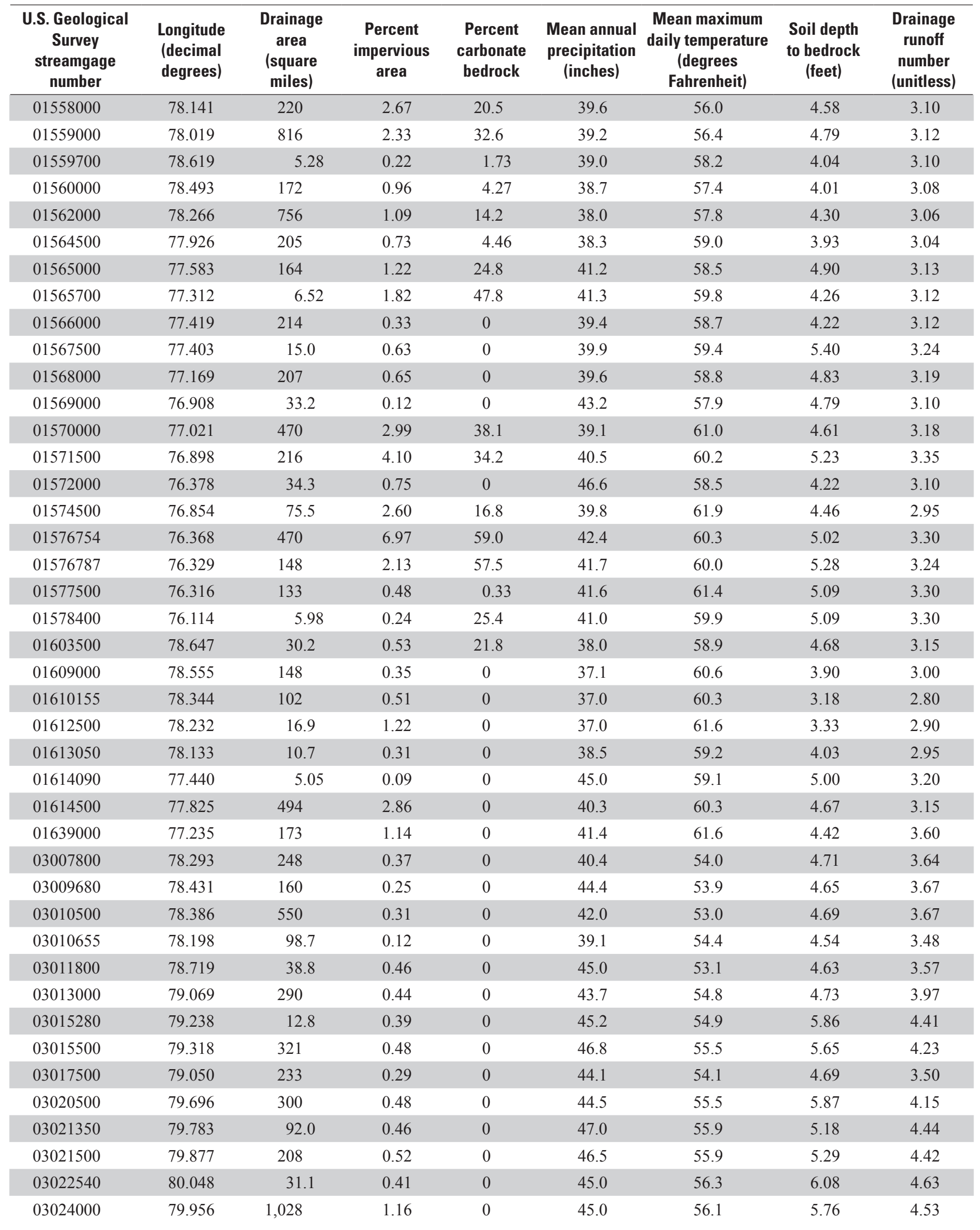


Appendix 3. Basin characteristics used in the development of flow-duration regression equations.-Continued

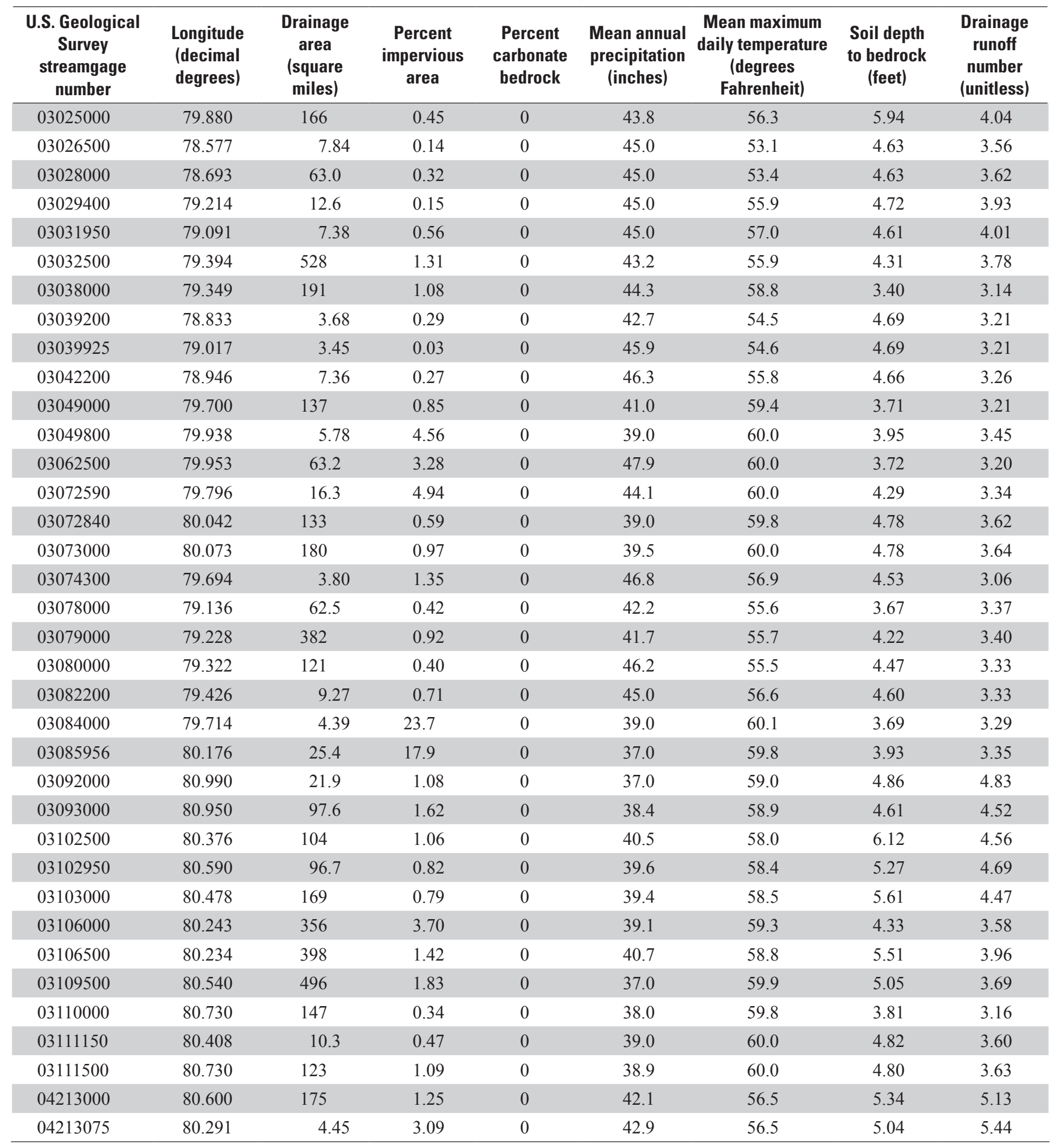




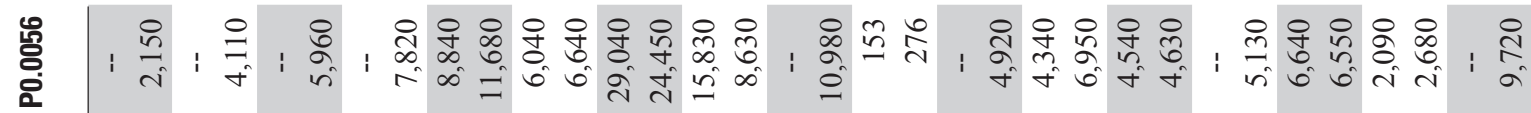

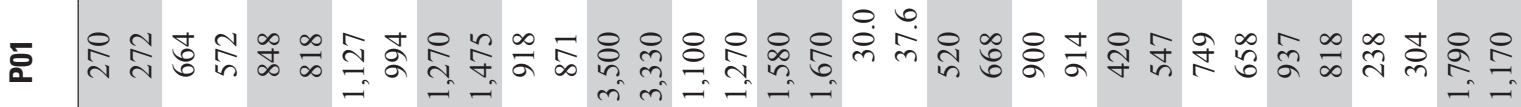

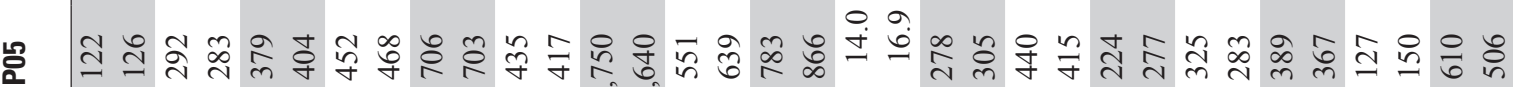

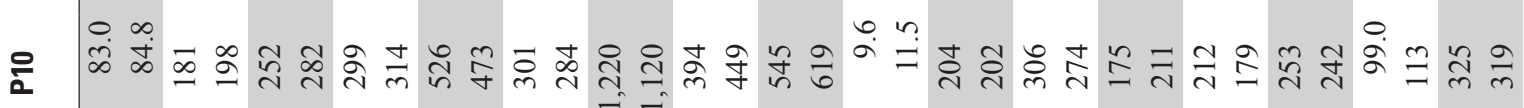
놈

నై

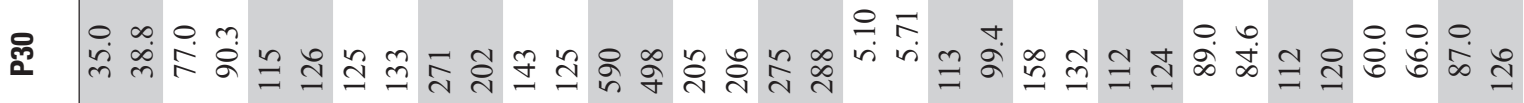
g 岤

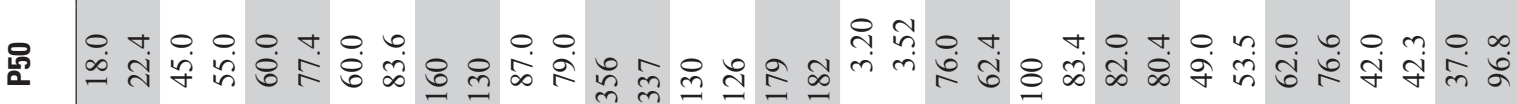
or o m o g. ष्ठ 을 穴

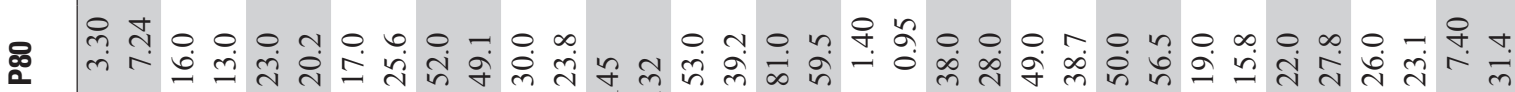

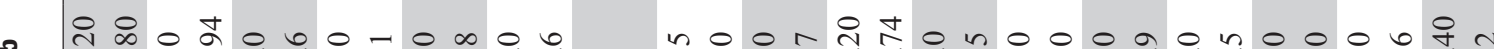
ஹ எ

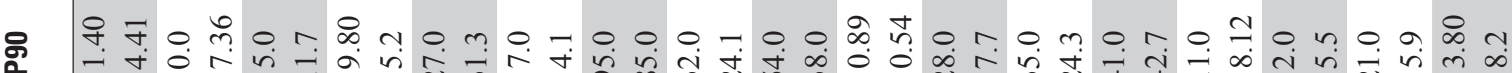

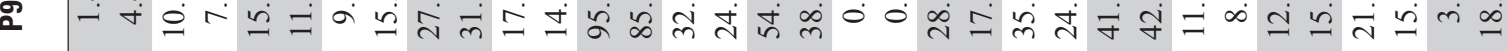

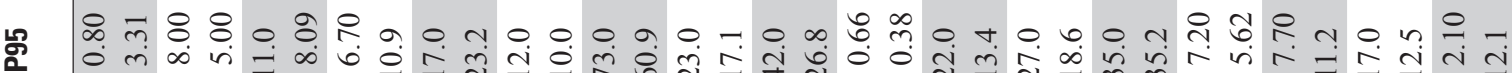

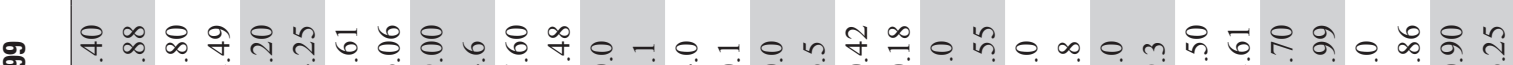

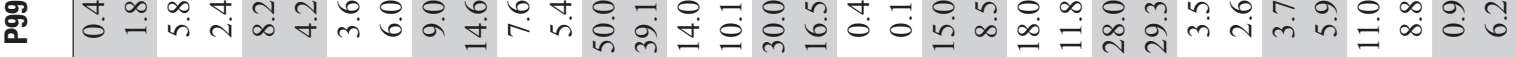

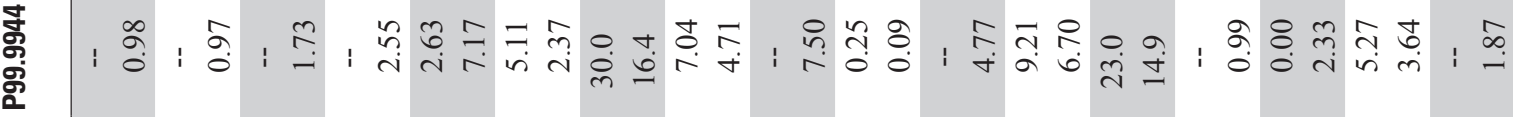

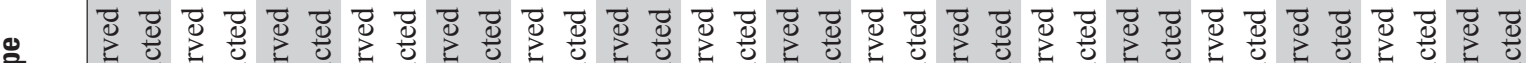

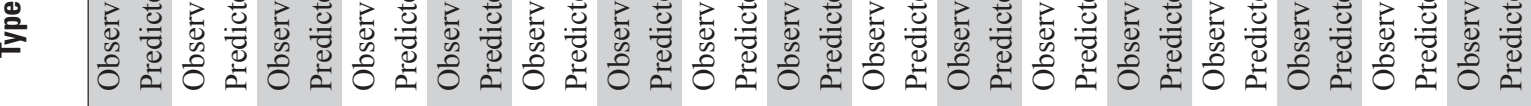

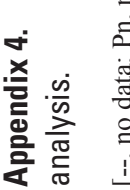

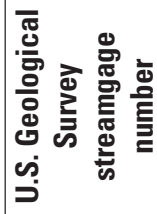

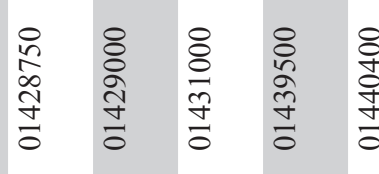
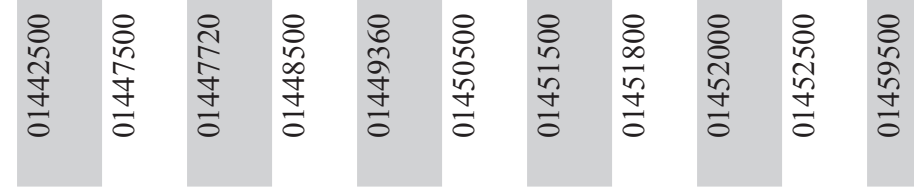


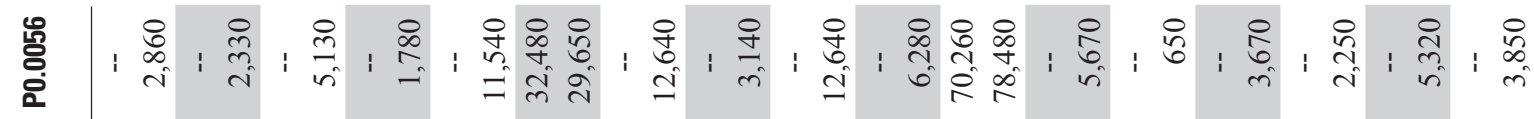
হa 놈

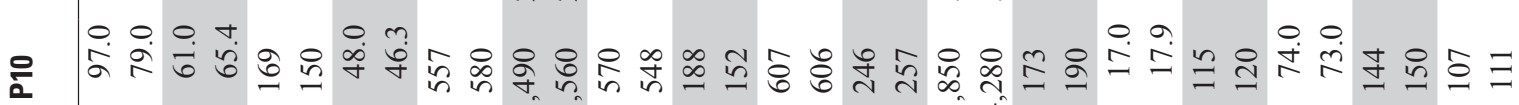

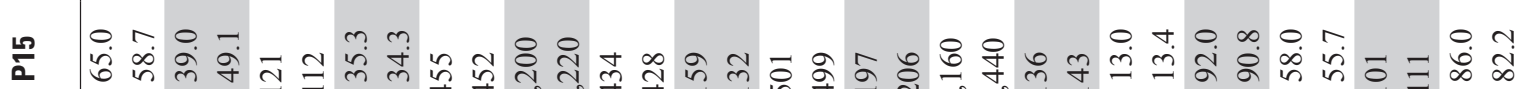

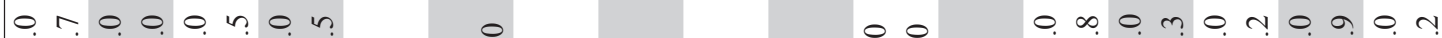

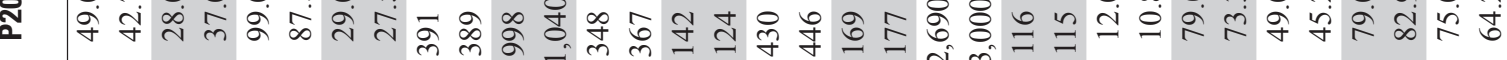
ஜ ๓

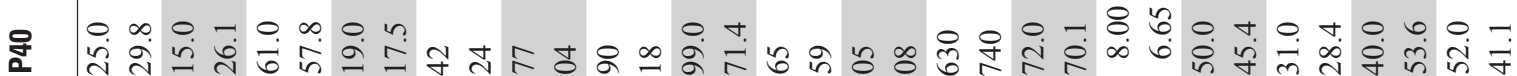

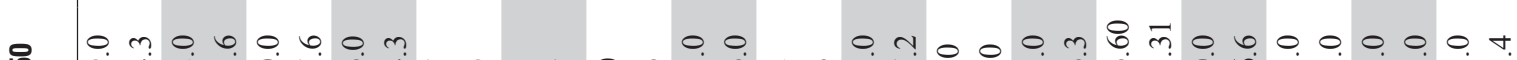

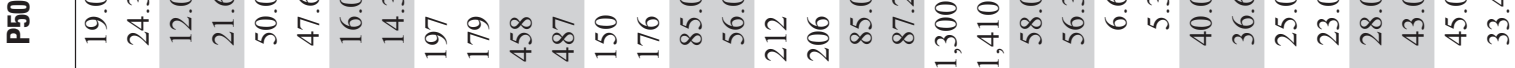

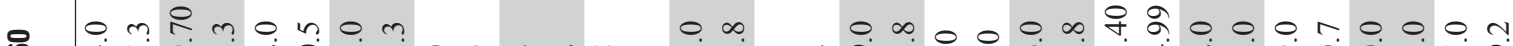

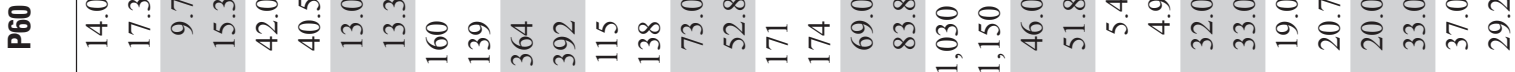

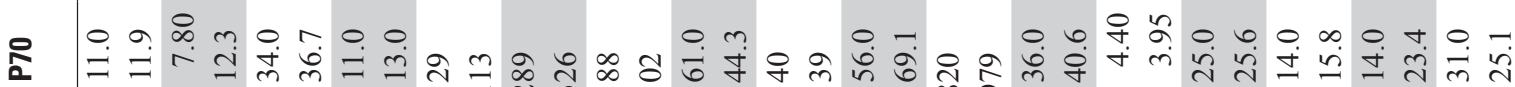

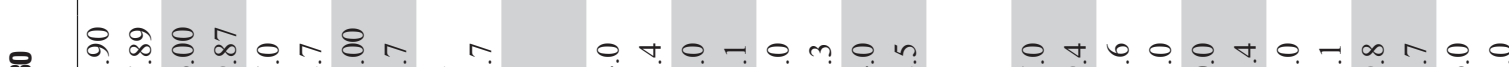
๓

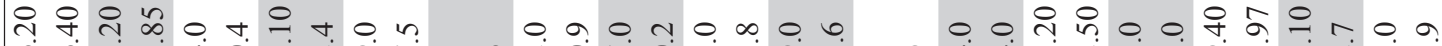
ळ b

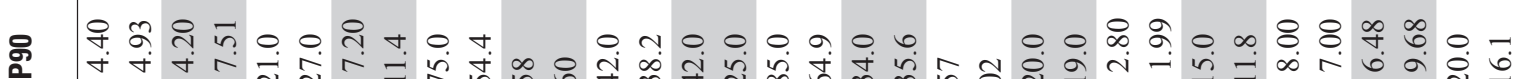

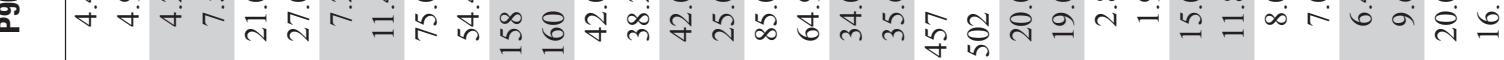

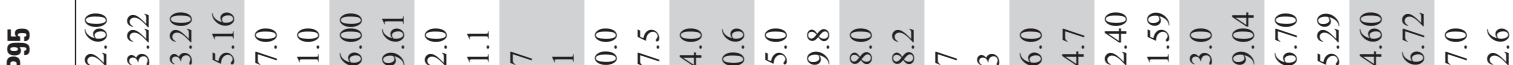

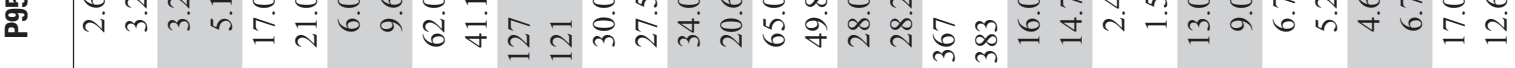

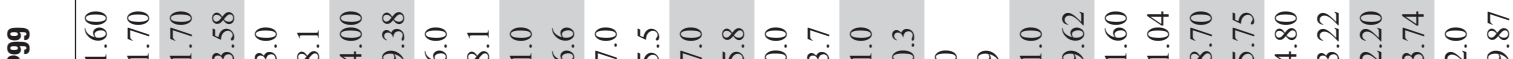

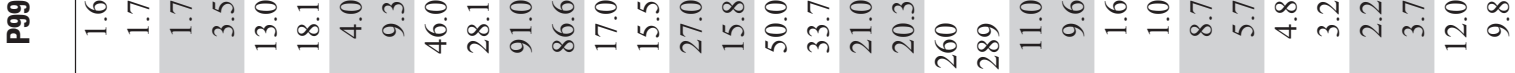
$\mid$

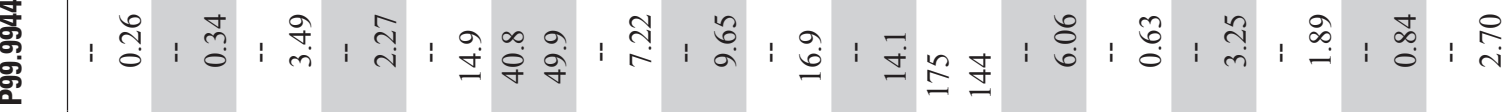

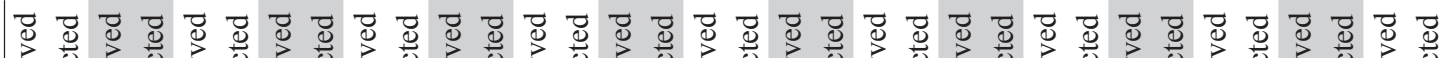

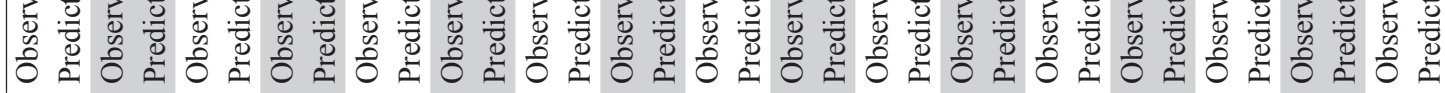




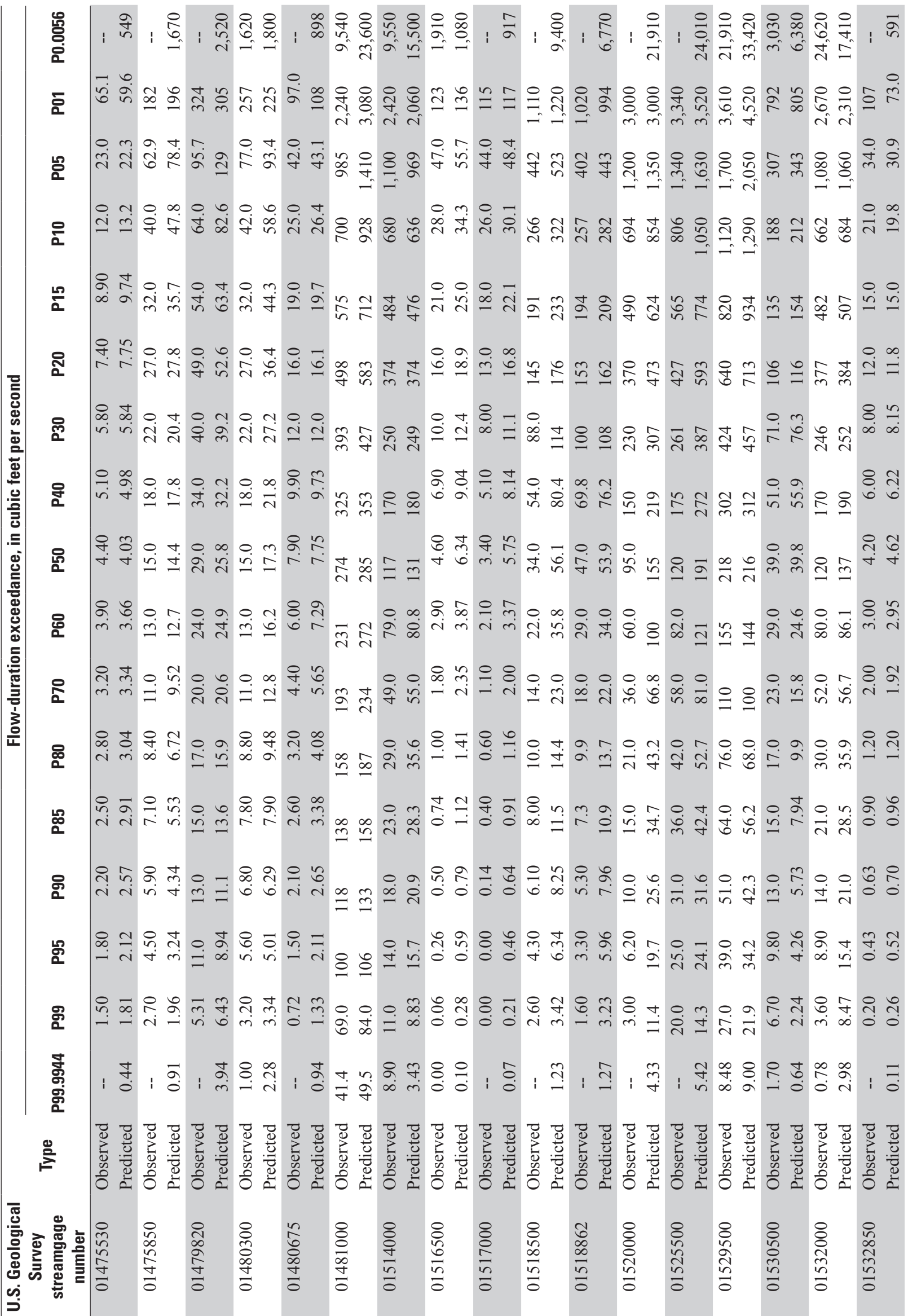




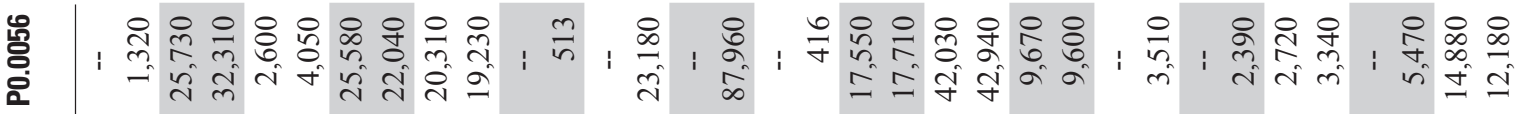

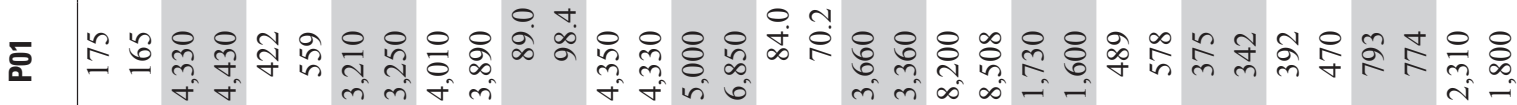
L

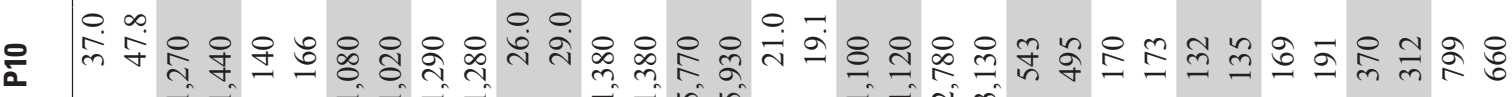

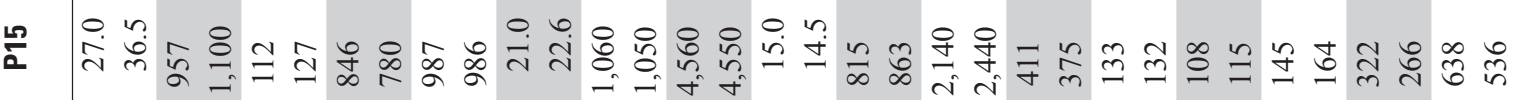

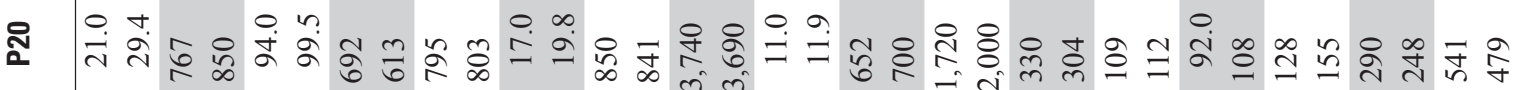

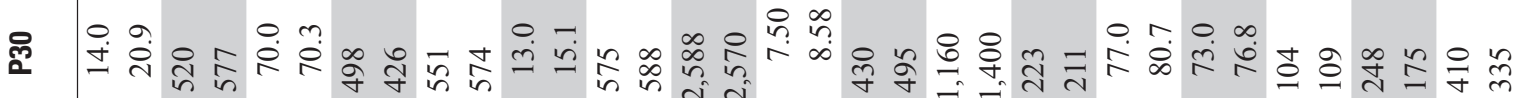

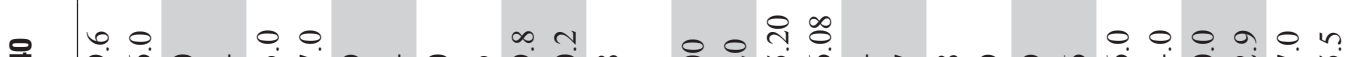

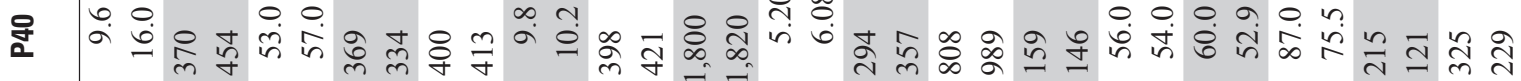

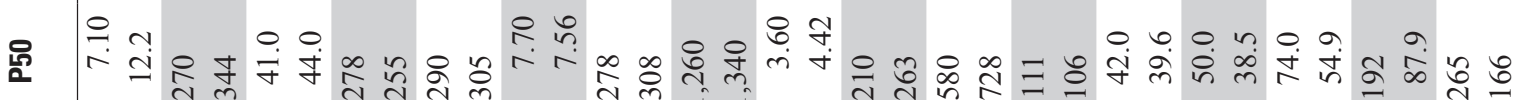
o

a 节 冓 穴

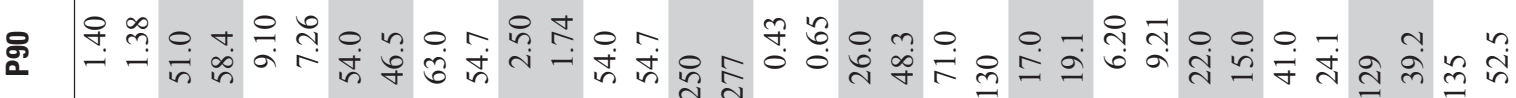

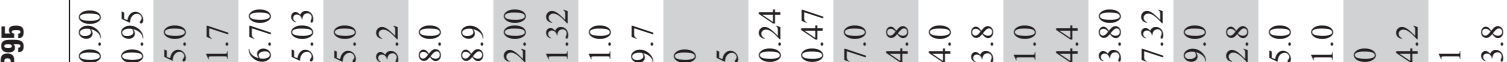
D O

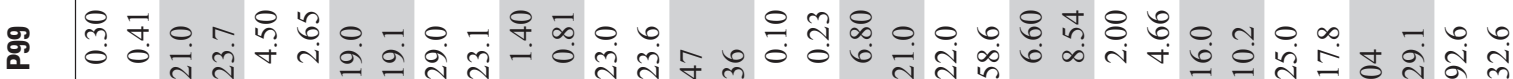
Z 尊 $\quad$ |

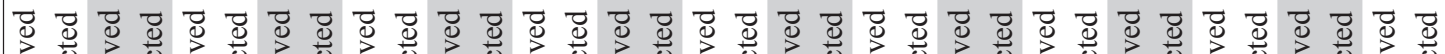
$\stackrel{2}{ٍ}$

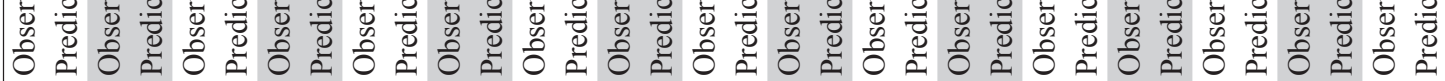




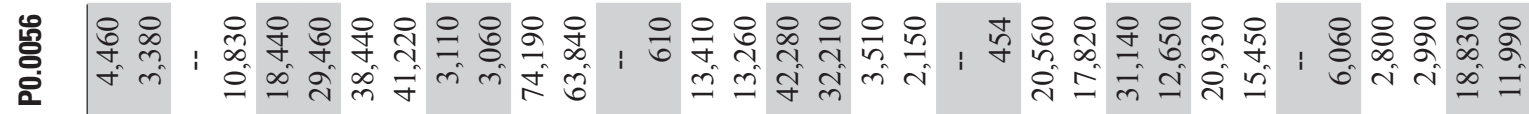
इ

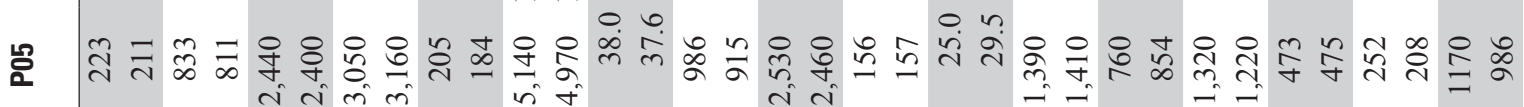

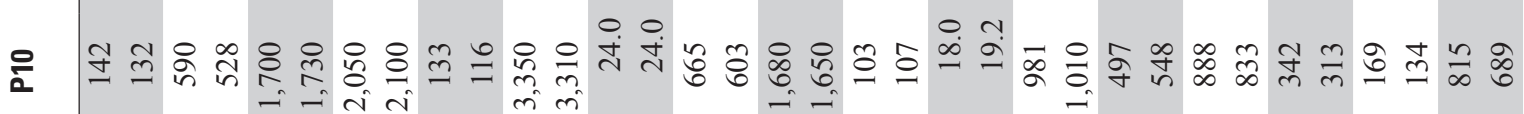

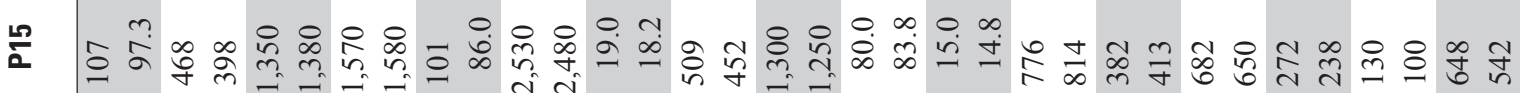

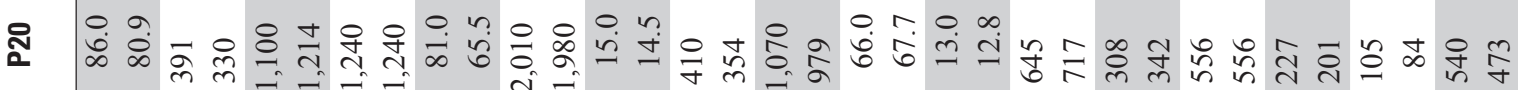

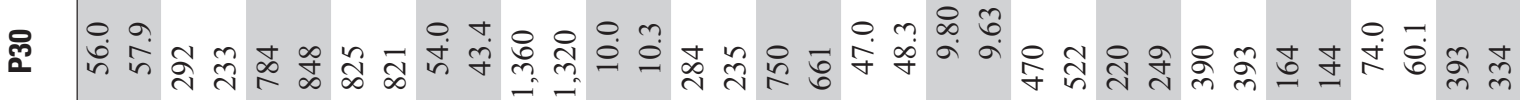

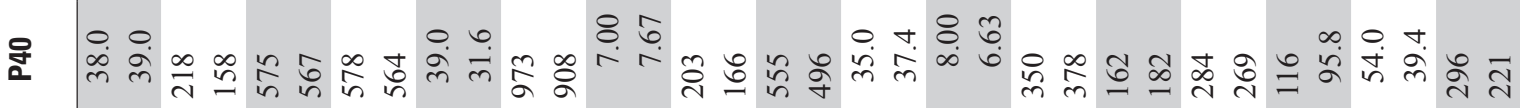

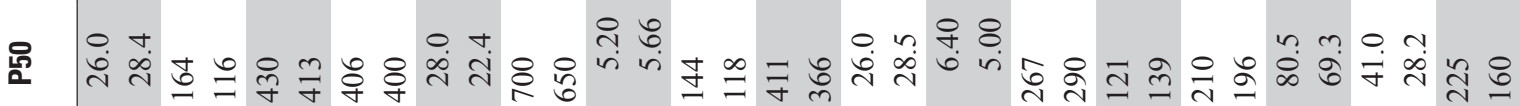

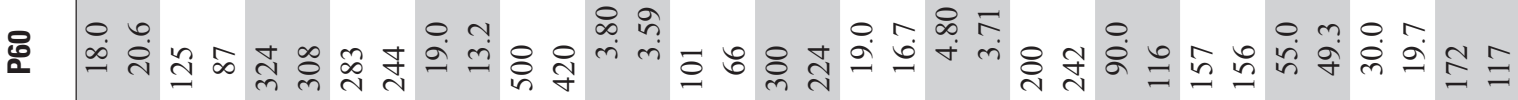

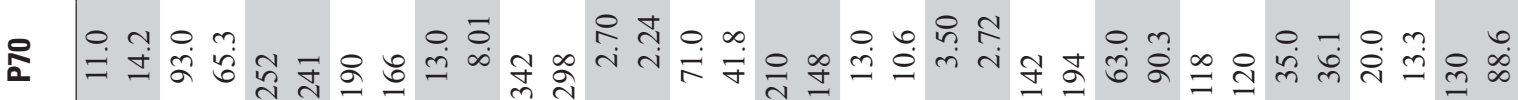

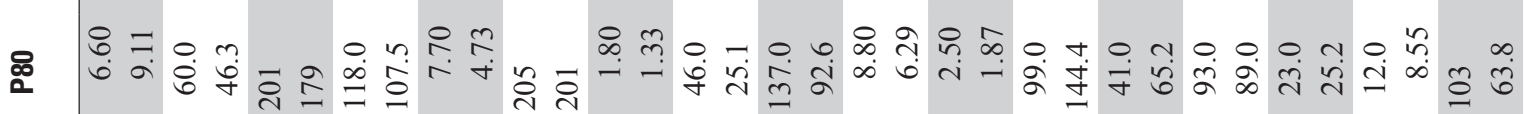

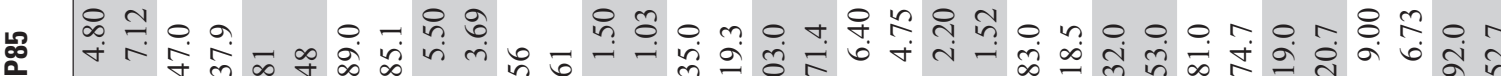

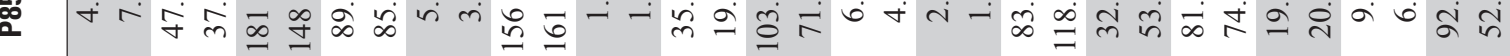

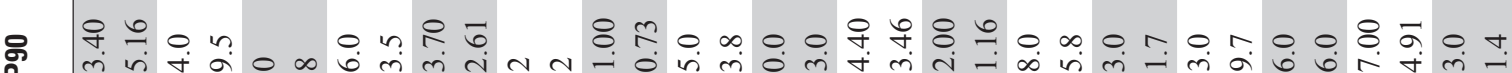

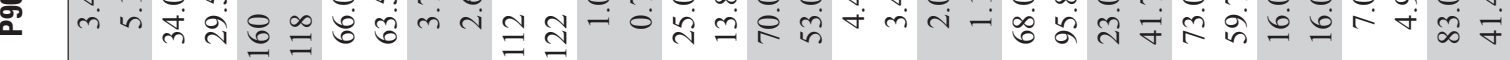

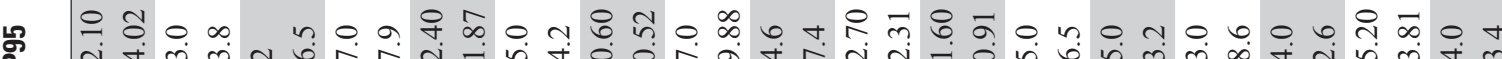

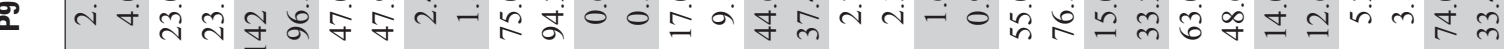
ภ 幕

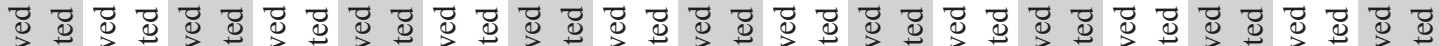
$\stackrel{2}{2}$

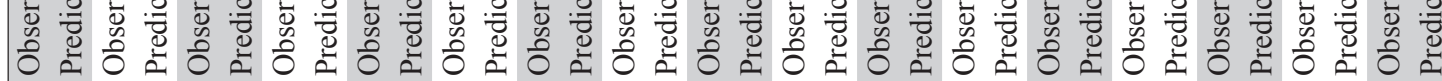




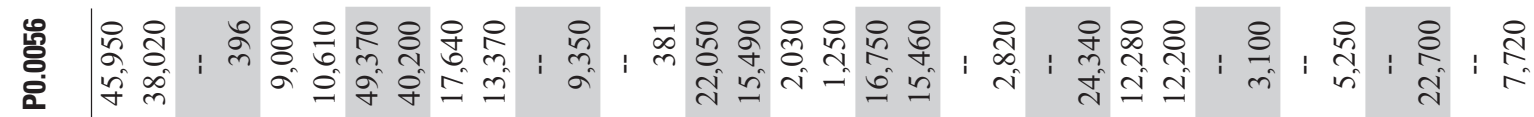

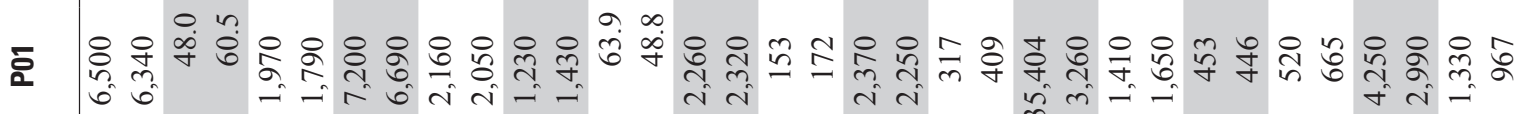

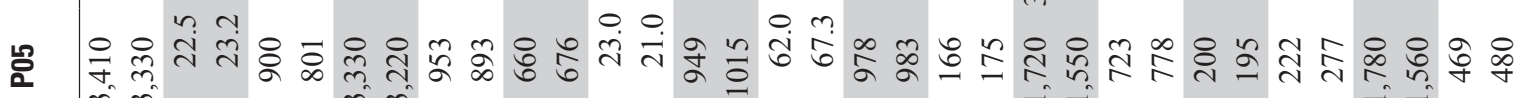

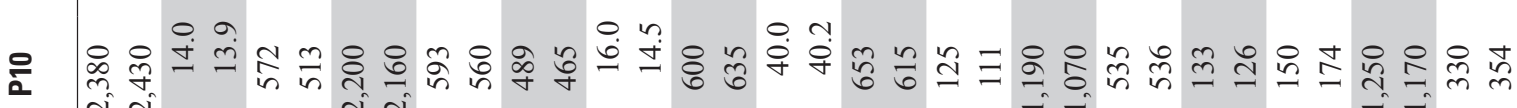

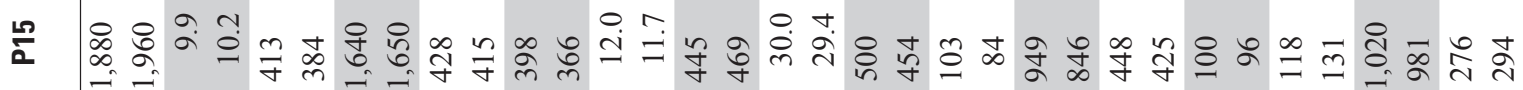

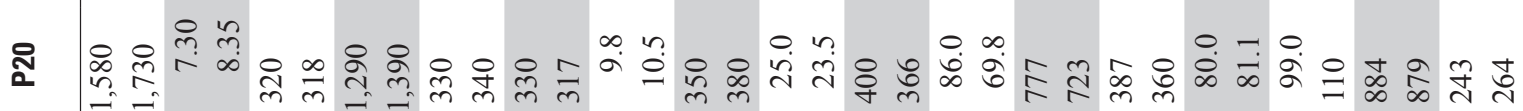

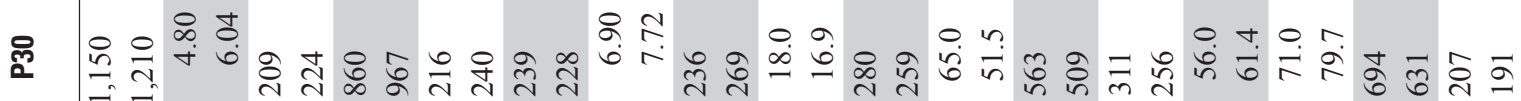

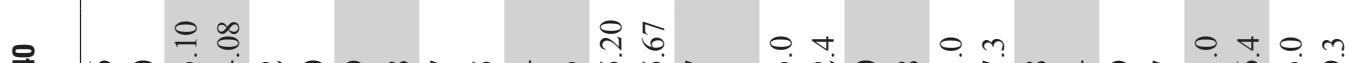

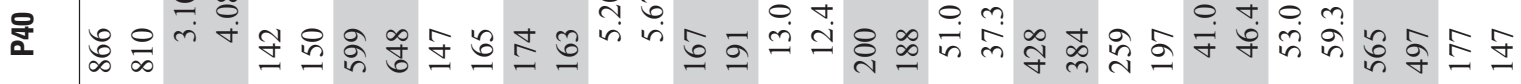

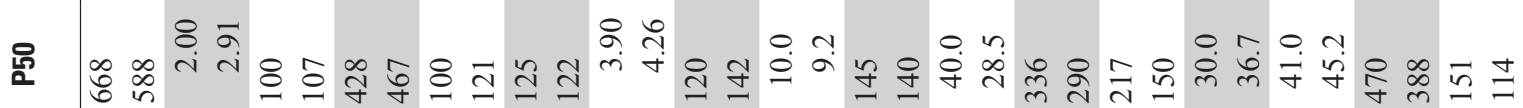

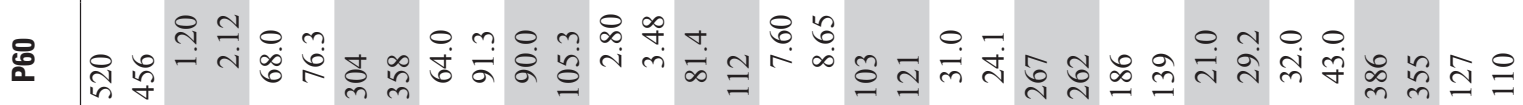

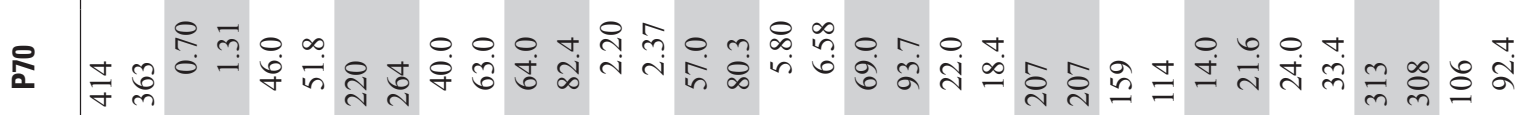

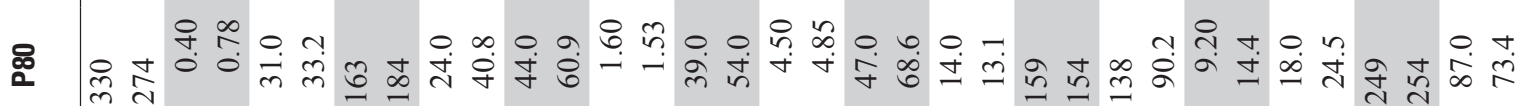

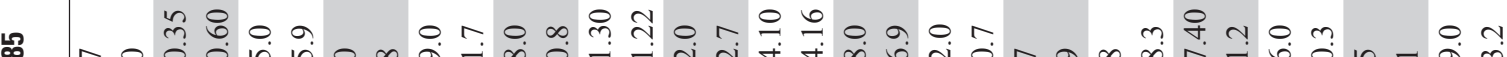

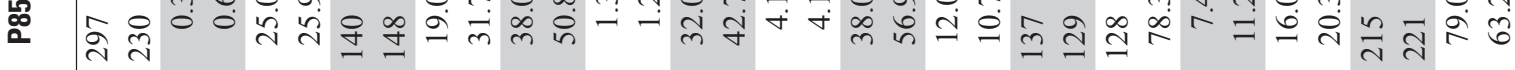

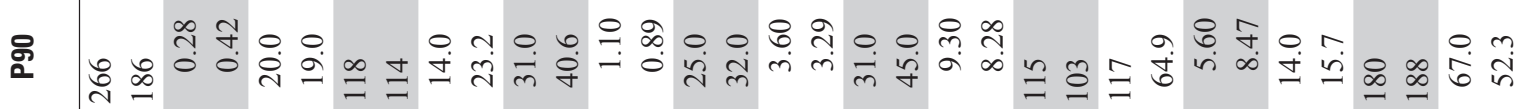

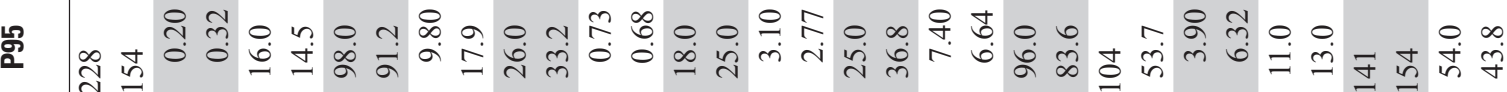

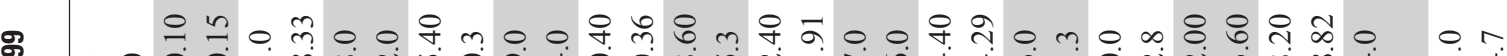

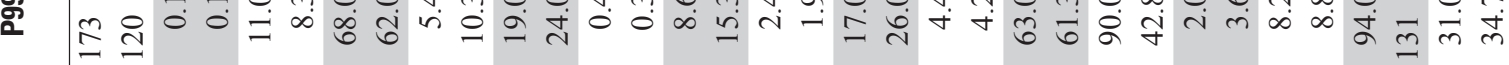

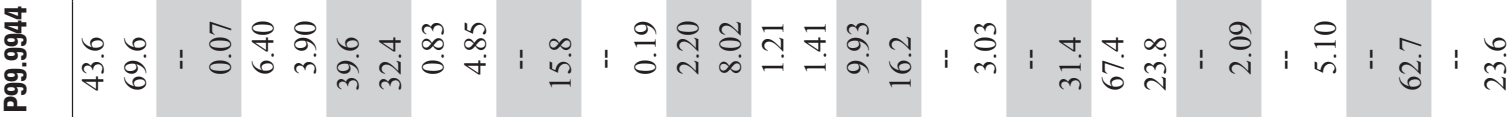

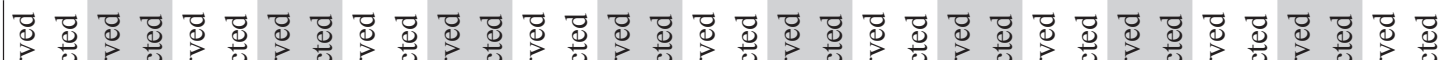
$\stackrel{2}{\stackrel{2}{\Sigma}}$

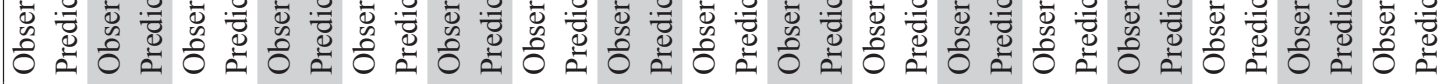

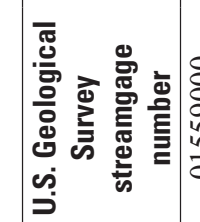
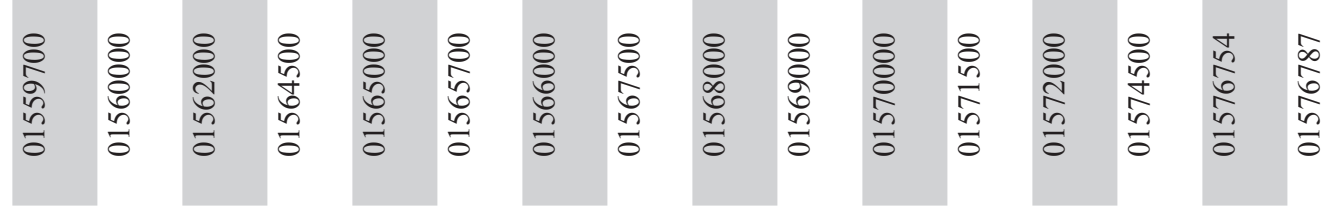


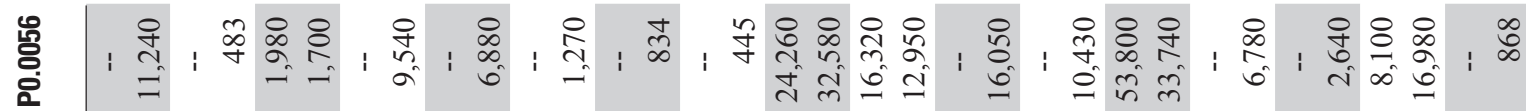

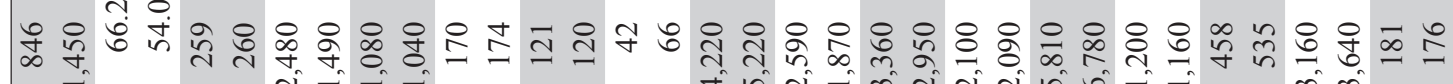

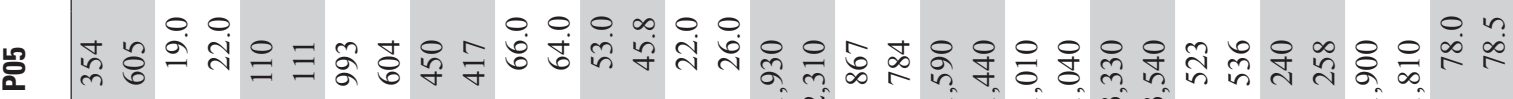

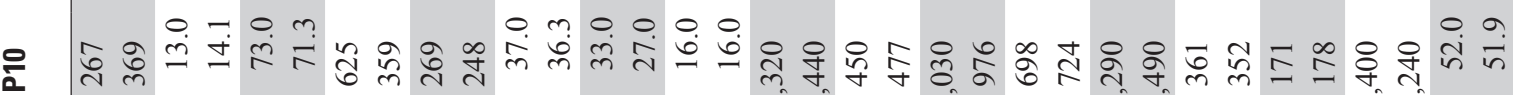

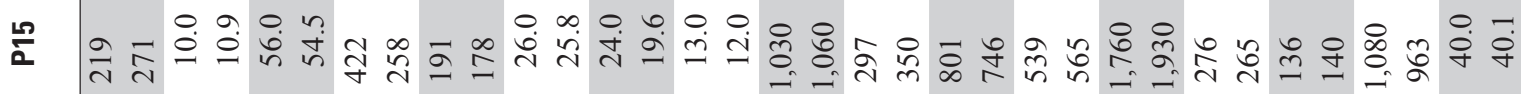

จ

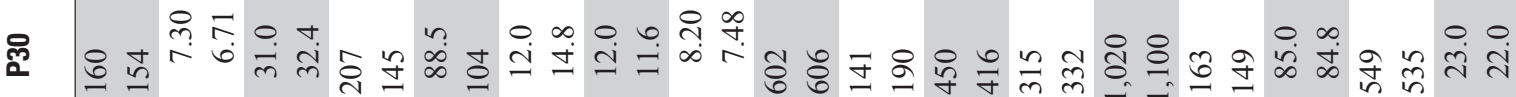

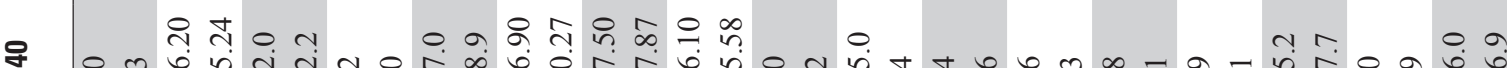

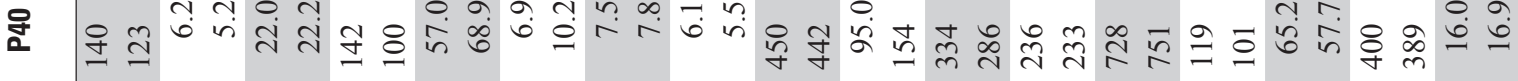

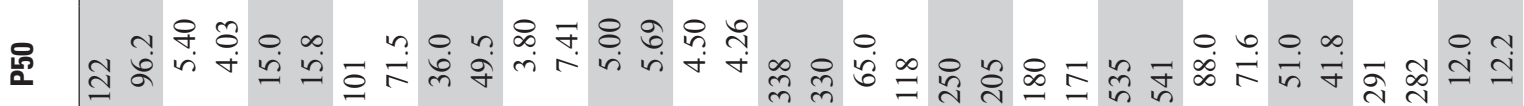

- प \&

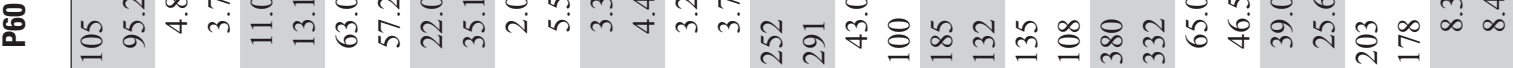

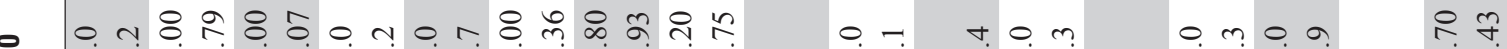
ถి

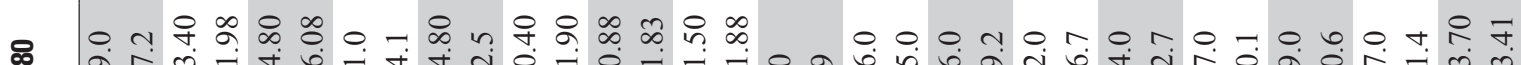

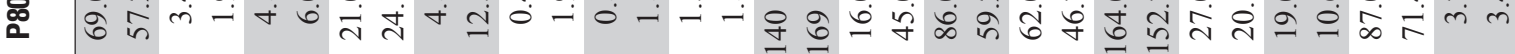

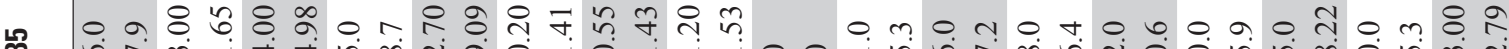

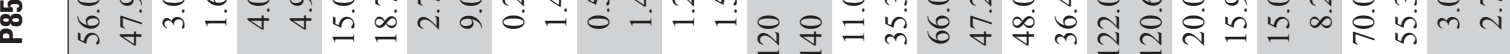

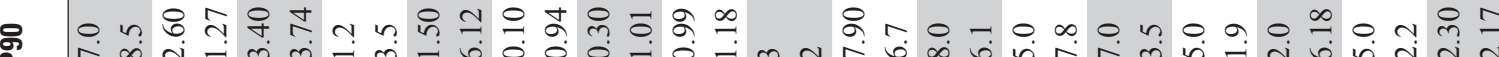
क 舟

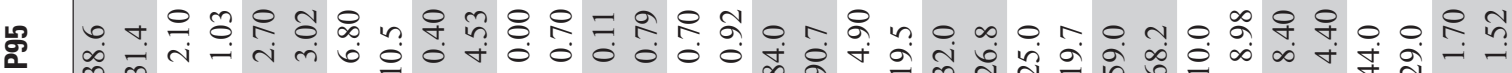

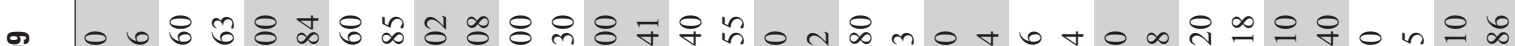
舟

费 |

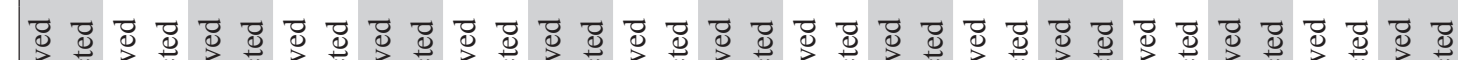




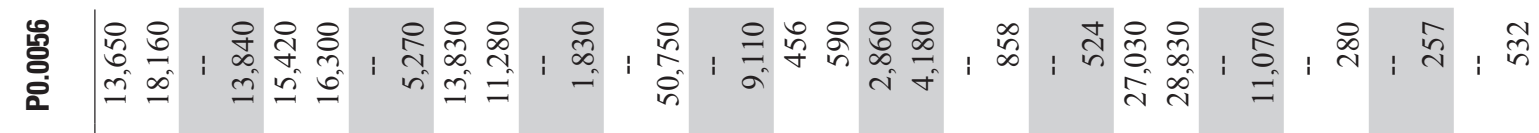

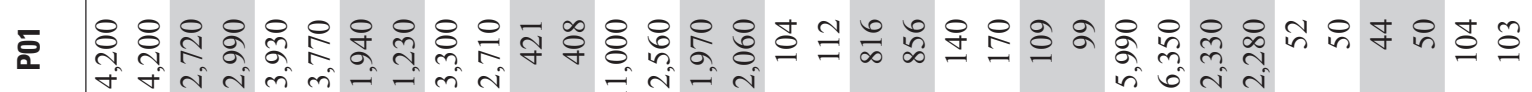

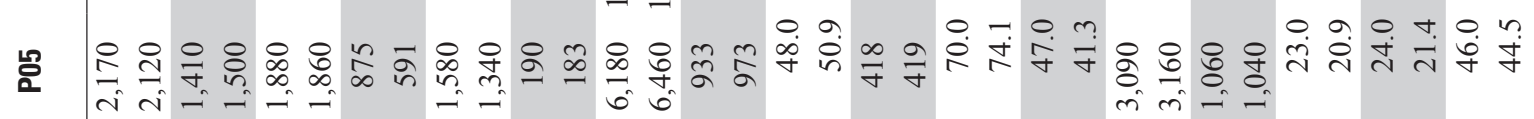

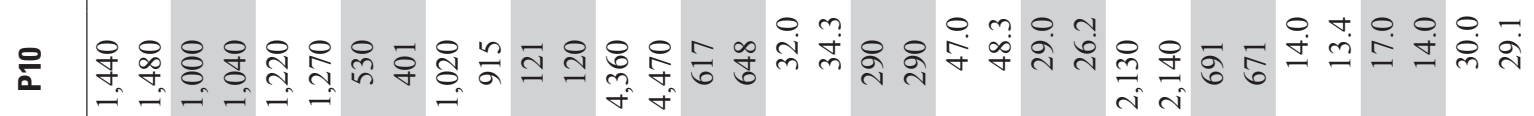

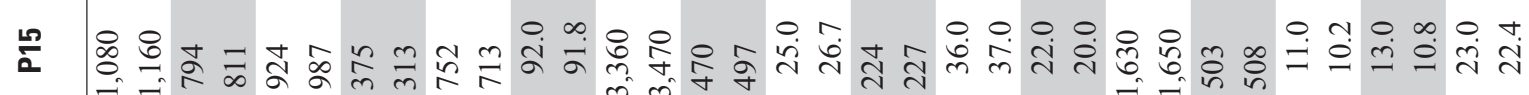
จิ สิธ

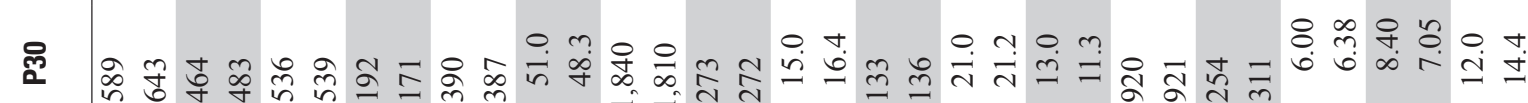
d

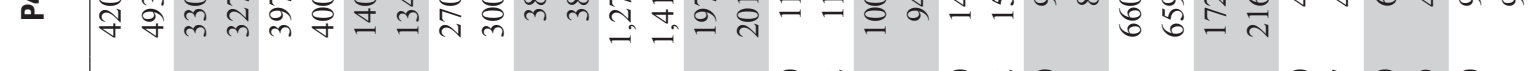

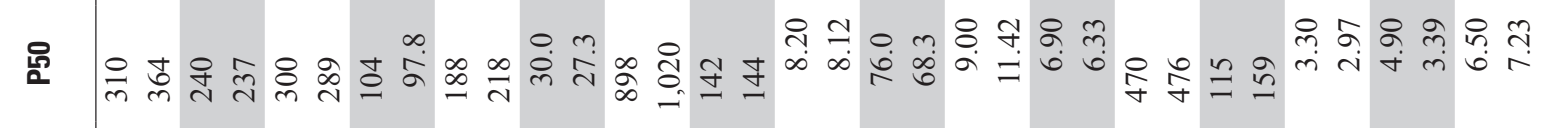

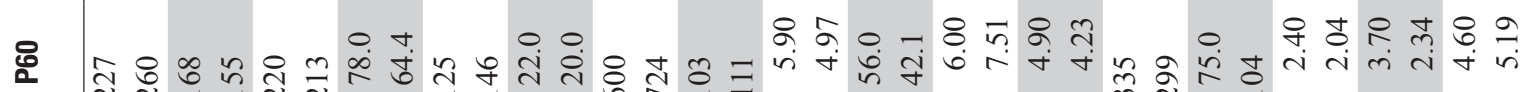

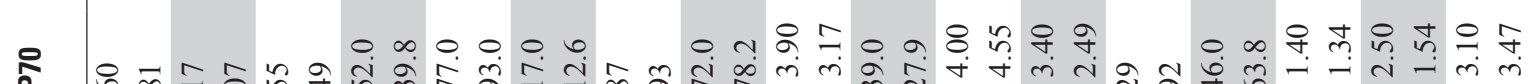

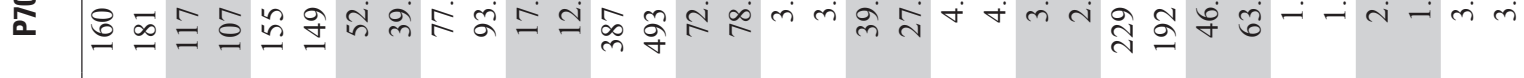

ஐ

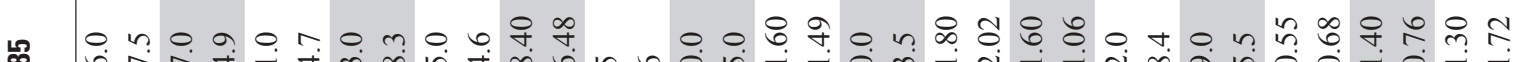

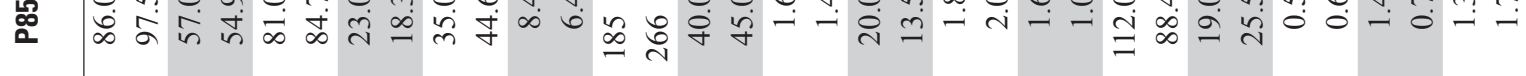

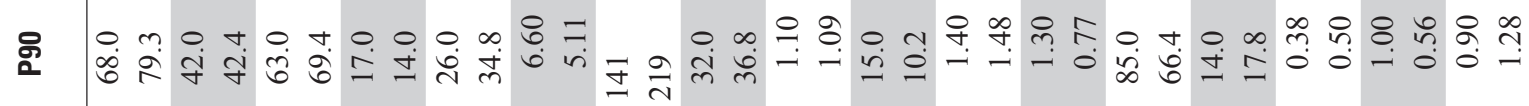
L

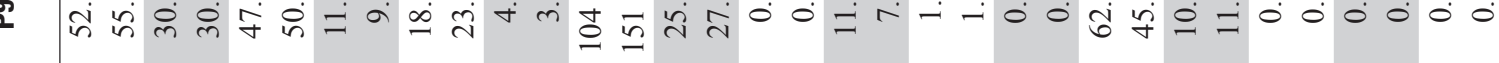

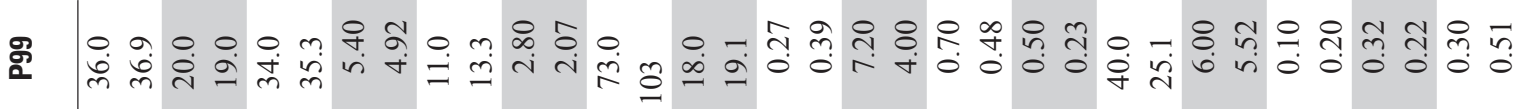
寄

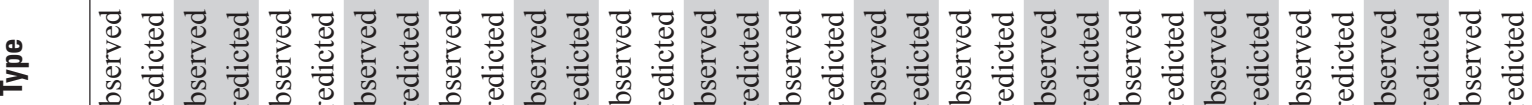

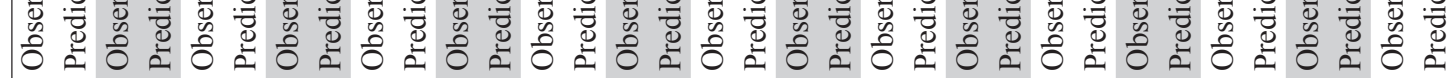




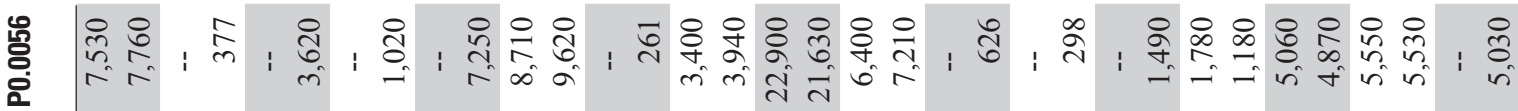

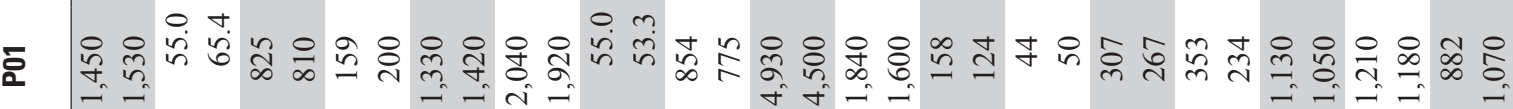

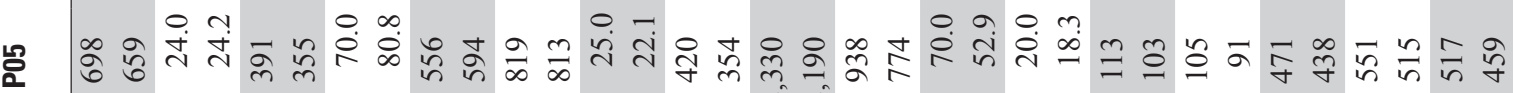

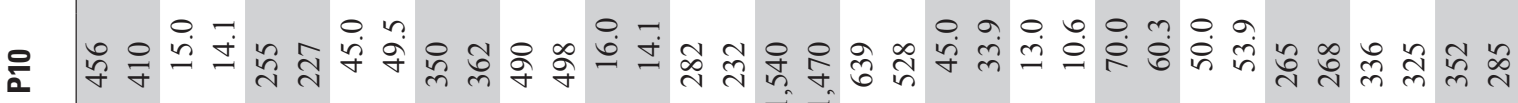

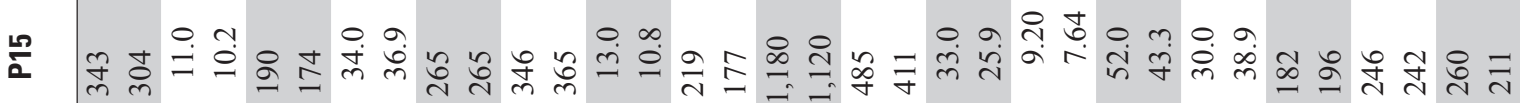

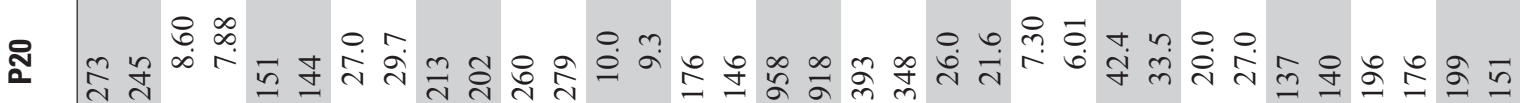

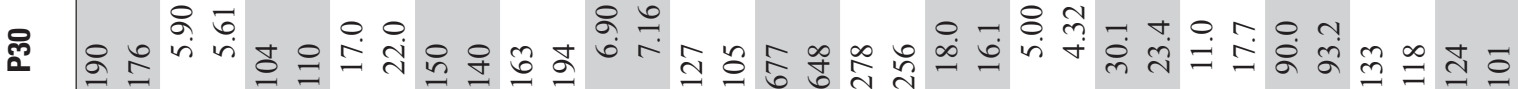

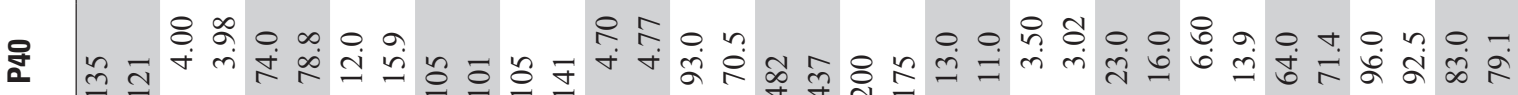

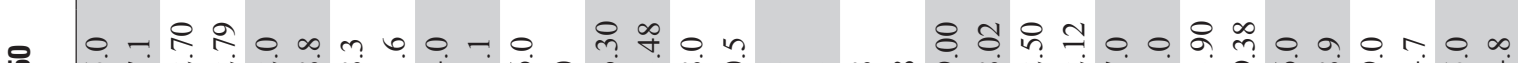

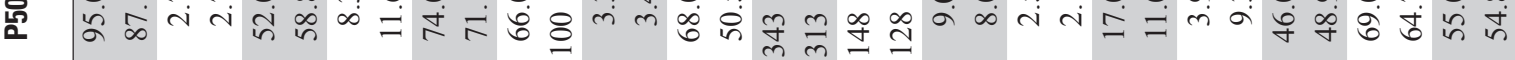

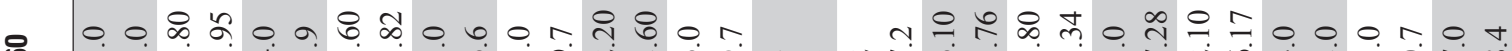

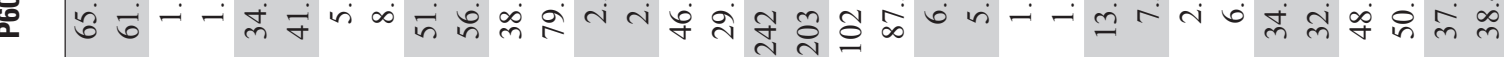

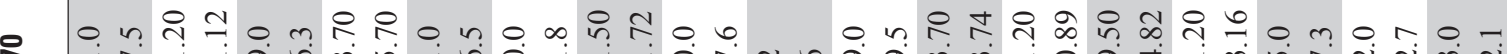

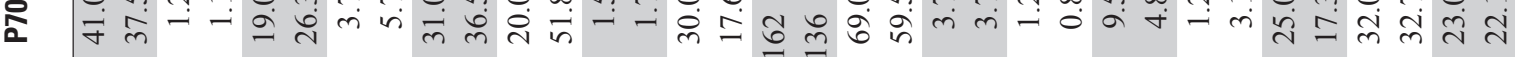

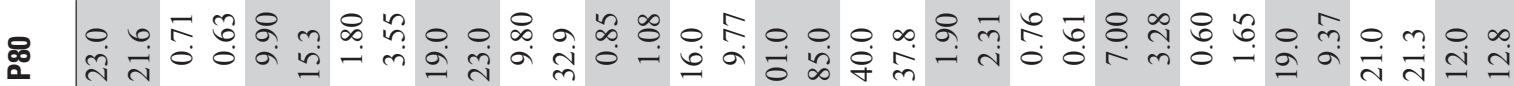

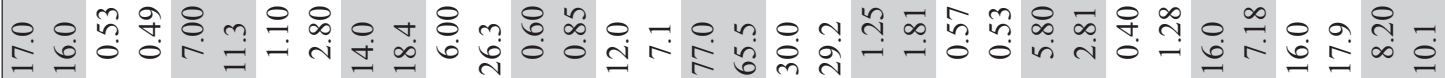

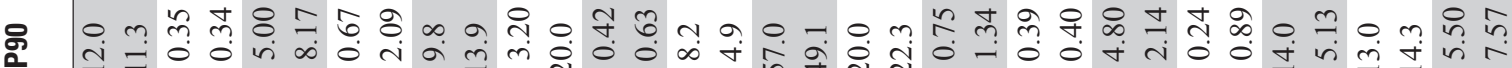

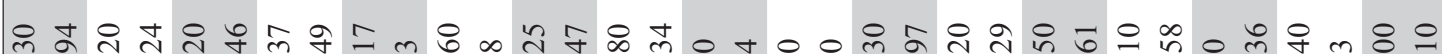

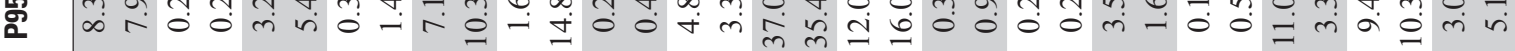

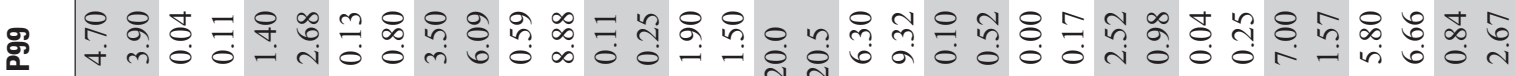

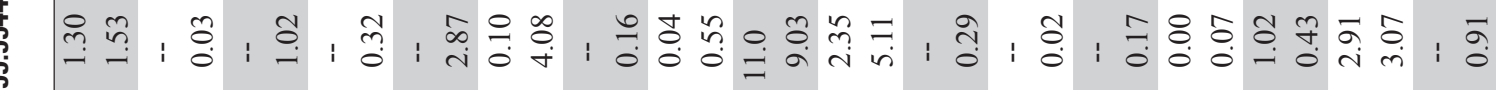

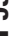

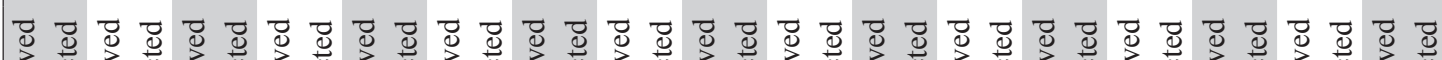

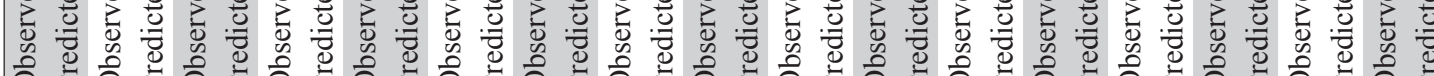

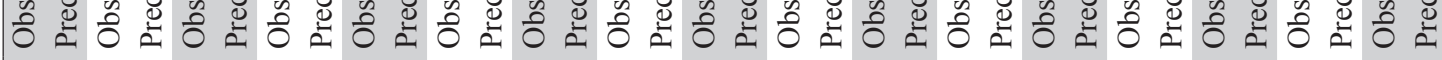




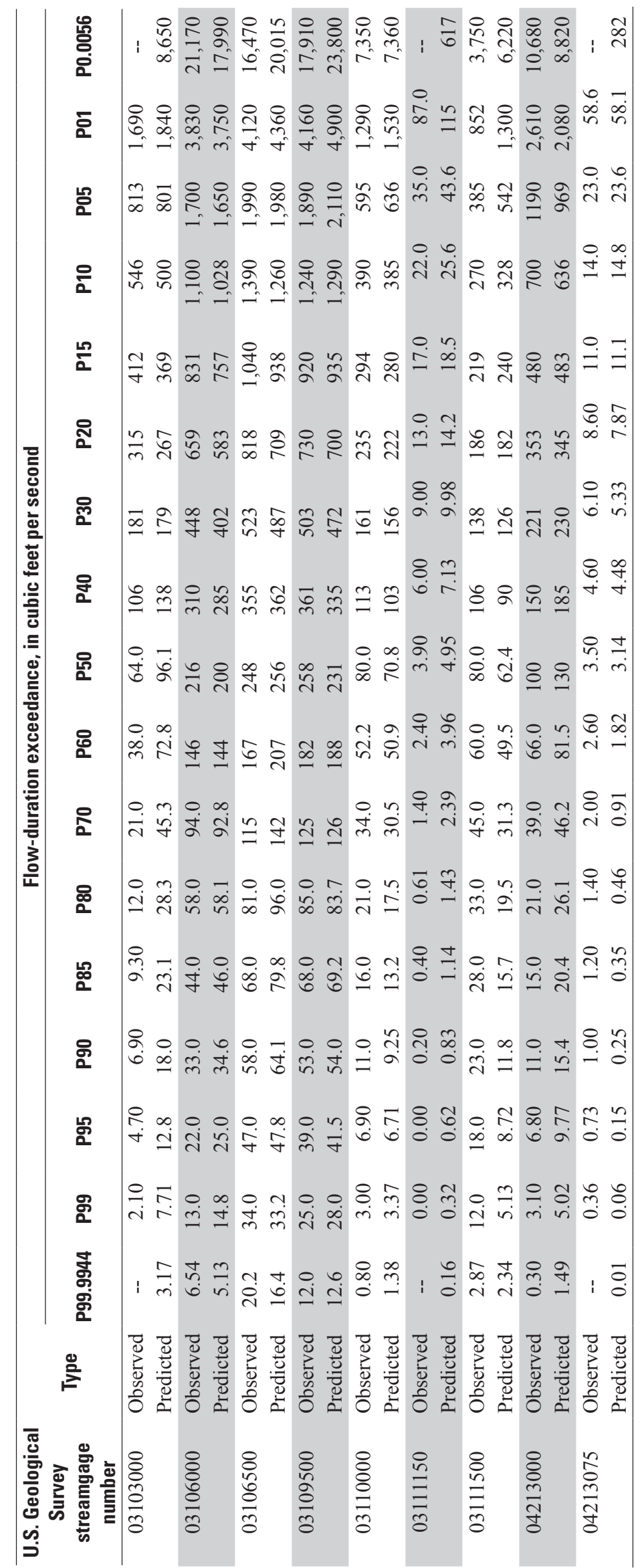


Prepared by the West Trenton Publishing Service Center

For additional information write to:

Director, Pennsylvania Water Science Center

U.S. Geological Survey

215 Limekiln Road

New Cumberland, PA 17070-2424

http://pa.water.usgs.gov/ 

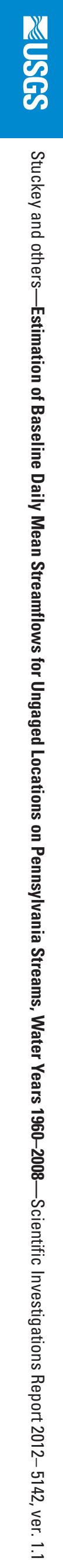